\title{
Black Sea Aquaculture: Legacy, Challenges \& Future Opportunities
}

\author{
Fabio Massa ${ }^{1, *}$ (D), Ilhan Aydın'2, Davide Fezzardi ${ }^{3}$, Bilal Akbulut ${ }^{4}$, Alexander Atanasoff ${ }^{5}$, Atife Tuba Beken ${ }^{4}$, \\ Vitaliy Bekh ${ }^{6}$, Yuliia Buhlak ${ }^{7,8}$, Irina Burlachenko ${ }^{9}$, Erkan Can ${ }^{10}$, Stefano Carboni ${ }^{11}$, Fabrizio Caruso ${ }^{12}$, Murat \\ Dağtekin $^{4}$, Kostiantyn Demianenko ${ }^{13}$, Hayri Deniz ${ }^{14}$, Dilek Fidan ${ }^{4}$, Linda Fourdain ${ }^{15}$, Marco Frederiksen ${ }^{16}$, \\ Archil Guchmanidze ${ }^{17}$, Housam Hamza ${ }^{18}$, Jessica Harvey ${ }^{19}$, Magda Nenciu ${ }^{20}$, Galin Nikolov ${ }^{21}$, Victor Niţă ${ }^{20}$, \\ Muhammed Doğan Özdemir ${ }^{4}$, Elitsa Petrova-Pavlova ${ }^{22}$, Catalin Platon ${ }^{23}$, Gabriel Popescu ${ }^{24}$, Ferit Rad ${ }^{25}$, \\ Şafak Seyhaneyildiz Can ${ }^{26}$, John A. Theodorou ${ }^{7}$, Behnan Thomas ${ }^{16}$, Nicolò Tonachella ${ }^{27}$, Ekaterina \\ Tribilustova ${ }^{16}$, Irina Yakhontova ${ }^{9}$, Ahmet Faruk Yesilsu' ${ }^{4}$, Güzel Yücel-Gier ${ }^{26}$
}

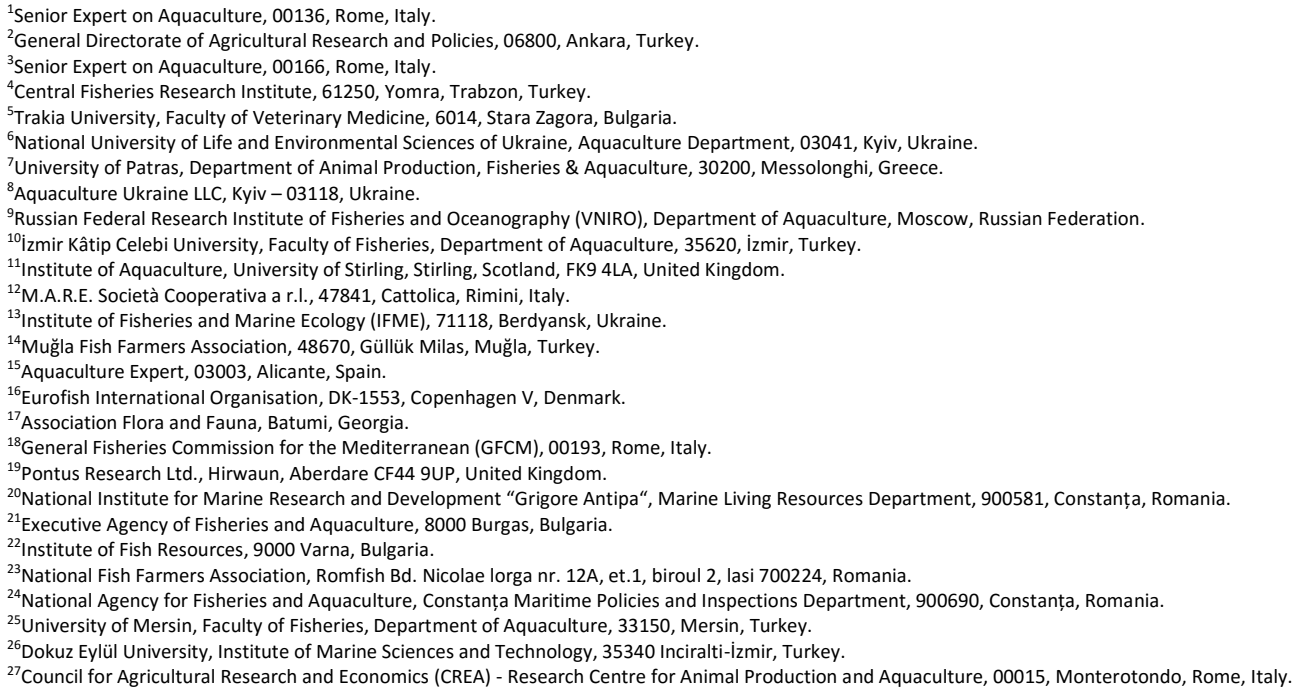

Massa, F., Aydın, I., Fezzardi, D., Akbulut, B., Atanasoff, A., Beken, A.T., Bekh, V., Buhlak, Y., Burlachenko, I., Can, E., Carboni, S., Caruso, F., Dağtekin, M., Demianenko, K., Deniz, H., Fidan, D., Fourdain L., Frederiksen, M., Guchmanidze, A., Hamza, H., Harvey, J., Nenciu, M., Nikolov, G., Niță, V., Özdemir, M.D., Petrova-Pavlova, E., Platon, C., Popescu, G., Rad, F., Seyhaneyildiz Can, S., Theodorou, J.A., Thomas, B., Tonachella, N., Tribilustova, E., Yakhontova, I., Yesilsu, A.F., Yücel-Gier, G. (2021). Black Sea Aquaculture: Legacy, Challenges \& Future Opportunities. Aquaculture Studies, 21, 181220. https://doi.org/10.4194/2618-6381-v21_4_05

\section{Article History}

Received 23 November 2020

Accepted 19 July 2021

First Online 30 July 2021

\section{Corresponding Author}

Tel.: +393498360010

E-mail: fabiomassa1@outlook.it

\section{Keywords}

Black Sea

Aquaculture

Marine spatial planning

Stock enhancement

Diversification

\begin{abstract}
Responsible aquaculture, the farming of aquatic organisms, is a sustainable strategic sector for land and coastal communities. It significantly contributes to food security and enhancement of economic development; it provides employment opportunities and often contributes to the ecological services provided by the environment. According to the Food and Agriculture Organization of the United Nations, the contribution of aquaculture to the global food security is widely demonstrated by an astounding industry growth of $7.5 \%$ per year since 1970 . In 2018, aquaculture reached the all-time highest production of 114.5 million tonnes in live weight with a total farm gate sale value of USD 263.6 billion. This makes aquaculture a key player within the Blue Growth concept and a strong contributor to some of its key Sustainable Development Goals. This is particularly true in geographical areas where dependence of local economies on fishery products is high, and yet access to sustainable landings is hampered by ecological barriers. One such area is represented by the Black Sea basin. Whilst the Black Sea annual capture fishery production has varied considerably since 1990 and its current landings are significant, growing attention is currently given to boost aquaculture development along the Black Sea bordering countries, with marine aquaculture being considered as an important contributor to the total fisheries production. Nonetheless, aquaculture development in this region is not homogenous and its development has, so far, been limited by environmental, economic, social, and more generally governance issues.

This paper, for the first time, attempts to provide a comprehensive fresh outlook of the aquaculture sector in the Black Sea, stressing the importance of regional cooperation as an essential pillar to support the sustainable development of the industry. The paper addresses aquaculture in the Black Sea from different perspectives: it outlines the key characteristics of the Black Sea environment; it discusses the most common farmed aquatic species and the potential for new ones; it frames the national approaches to aquaculture development, sharing information about success stories, while shedding light on the main challenges and priorities ahead. This collective endeavour will represent a helpful contribution to Black Sea riparian countries to answer the many questions they have, and expectations they hold from the aquaculture sector.
\end{abstract}




\section{Introduction}

\subsection{The Black Sea, A Marine Environment for International Cooperation Towards Sustainable Aquaculture Development}

The Black Sea represents a unique environment from ecological, economic, and social points of view. For centuries, this basin has provided coastal communities with an abundance of marine living resources, which boosted the development of thriving local fishing industries and contributed to local socio-economic development. The Black Sea location, its connection with the Mediterranean, and its semi-enclosed nature, allowed for marine trade to thrive for centuries. It has also significantly contributed to building the identity of many civilizations contributing to the cultural and social structure of the region (FAO, 2018g).

Owing to its geographical characteristics and socioeconomic importance, the Black Sea basin and its ecology is one of the most studied marine systems in the world. The coastal and shelf zones of the Black Sea are endowed with natural resources and ecological communities, and include an array of ecosystems with a relevant economic importance, that interact among them and where human activities flourish (Bakan and Büyükgüngör, 2000). The Black Sea is a Large Marine Ecosystem (LME) (Golumbeanu and Nicolaev, 2015) and the world's largest land-locked sea. Connected to the Sea of Azov by the Kerch Strait in the North, the Black Sea is supplied by several major rivers, including the Danube, the Dnieper and the Don, Europe's three largest rivers. It ultimately drains into the Mediterranean Sea, through the Turkish Straits and the Aegean Sea (Bakan and Büyükgüngör, 2000; Shalva, 2002).

The Black Sea presents distinctive physical, chemical and ecological characteristics when compared with the neighbouring Mediterranean Sea. A thin (100 m depth) upper layer of lighter marine water (with lower salinity and density) supports life in the Black Sea ecosystem, and a pycnocline separates it from the deeper and more dense water layers, saturated with hydrogen sulphide, that over thousand years has accumulated from decaying organic matter in the basin, causing permanent anoxic conditions beneath 100-200 $m$ depth (Murray et al., 1989; Tugrul et al., 1992; Bakan and Büyükgüngör, 2000; Salihoglu, 2000; Friedrich et al., 2002). Indeed, more than 90 percent of the Black Sea water is devoid of oxygen, making it the largest anoxic water body on our planet (Sorokin, 1983; Bakan and Büyükgüngör, 2000; Stanev, 2005). Due to these challenging oceanographic conditions, the biodiversity of the Black Sea is approximately three times less than that of the Mediterranean (Black Sea Commission, 2019), and its specific features in terms of oceanography, geographical location and climate make it very vulnerable to disturbances of its habitats and ecosystems (Zolotarev, 1996; Kideys, 2002; EEA, 2015;
Black Sea Commission, 2019).

Despite these characteristics, the Black Sea coasts host biologically productive and diverse ecosystems that provide a vital habitat for many birds, mammals, and fish species (Bakan and Büyükgüngör, 2000; Kideys 2002; Salihoglu, 2000). Indeed, it supports an active and dynamic marine environment, dominated by species suited to the brackish and nutrients-rich conditions (Zaitsev and Mamaev, 1997; Bakan and Büyükgüngör, 2000). Because of the limited extension of the continental shelf and the anoxic nature of the deeper water layers, fisheries resources are confined to the upper part of the water column, where they have been exposed to a progressively increasing fishing exploitation during the last decades (FAO, 2018g).

After the collapse of the pelagic stocks fisheries at the end of the 1980s and the abrupt ecological shift toward a trophic system led by gelatinous carnivores, such as the alien ctenophore Mnemiopsis leidyi, several studies aimed at elucidating which factors triggered this ecosystem changes. These studies concluded that since the early 1970s, the combined effect of successive overexploitation of fish stocks, increased pollution and eutrophication of the basin, population outbursts of alien planktonic carnivores and strong decadal-scale climatic fluctuations, were the most significant factors leading to the observed environmental deterioration (Caddy, 1993; Zolotarev, 1996; Prodanov et al., 1997; Gucu, 2002; Daskalov et al., 2007; Kideys, 2007; Oguz and Gilbert, 2007).

Fishery resources have always represented an important source of food and economic prosperity for the local communities. However, due to dramatic ecological changes that have occurred in the last decades (Sorensen et al., 1997; Zaitsev and Mamaev, 1997; Bakan and Büyükgüngör, 2000).

At present, the crucial transboundary challenges of the Black Sea region are linked to the environmental issues that have been affecting the ecosystem and the biodiversity of the basin. These can be included in the following main categories: (i) eutrophication/nutrient enrichment of the basin, (ii) changes in the marine living resources, (iii) chemical pollution (including oil), (iv) biodiversity and habitat changes, including the decline of fish stocks, and (vi) the introduction of alien species (UNEP/GEF 1997; Black Sea Commission, 2008; EEA, 2015).

Strengthened national efforts and fostered regional cooperation have been instrumental to the economies of the coastal states and, according to the available macroeconomic indicators, have brought some first signs of environmental recovery to the Black Sea in recent years. (Black Sea Commission, 2019). This recovery is still at an early stage even though environmental improvements are recognized (Black Sea Commission, 2019). Nonetheless, any level of additional anthropic pressure can once again compromise the delicate environment of the Black Sea. 
Knowledge driven policies and decision making, as well as cooperation and coordination between Countries in the region, are of paramount importance to protect the Back Sea environment. The recovery process of the Black Sea will take significant time and effort, requiring implementation of the existing measures as well as future decisions. The sustainable development of societies and the wellbeing of the coastal population is a priority for the Black Sea coastal states, and this has resulted in the need to strengthen cooperation at national and supranational level. According to the Black Sea Commission, the national and international efforts of the Black Sea coastal states shall be directed at two targets: 1) to prevent the increase of pressures from human activities when transitional economies of the Black Sea coastal states begin to recover, and 2) to achieve environmental conditions in the Black Sea similar to those reported before the ecological shifts (Black Sea Commission, 2019). Several international organizations with mandate over the Black Sea area (e.g.: FAO/GFCM) are committed to favouring the cooperation and the dialogue among Black Sea Riparian Countries, on matters including fisheries, aquaculture and natural resources management more generally. It remains that several international agreements and treaties apply to either the entire region, or only to some of its countries. The most important supranational agreements and frameworks in the Black Sea are reported in Table 1.

Cooperation on aquaculture development is also of attention to bordering countries, particularly as this sector has the potential to fill the gap left by reduction in capture fishery landings and, therefore, to improve livelihoods of local communities. One of the main springboards that improved cooperation on aquaculture was represented by the "First meeting of the ad-hoc
Working Group on the Black Sea" organised by the GFCM in Constanta (Romania) in 2012, where cooperation on aquaculture was put to the attention of all Countries. Within this effort, two key meetings laid the foundations for the regional cooperation on sustainable aquaculture: the first "High-level Conference towards Enhanced Cooperation on Black Sea Fisheries and Aquaculture" meeting was held in Bucharest (Romania) in 2016 (FAO, 2017) and the second was held in Sofia (Bulgaria) in 2018. These two events identified key priorities for aquaculture development in the region.

In these particular environmental, social and governance scenarios, aquaculture offers a great chance to provide sustainable sources of food, employment opportunities and economic development for the local communities (Niță et al., 2019). Undeniably, the countries bordering the Black Sea possess a great potential for aquaculture development as, at present, the region is not utilizing its aquatic resources to its available capacity. In recent years, rapid and significant progress has occurred within the aquaculture sector and development has occurred in some of the countries, while in others aquaculture has developed more gradually. Details of each country aquaculture development is outlined in the following sections.

\subsection{The Potential for Aquaculture Development in the Black Sea}

Environmental factors such hydrodynamic conditions, bathymetry, temperature and salinity, as well as water quality parameters (inclusive of contaminants and pathogens), have a strong influence on the growth and development of all marine organisms, including cultured finfish and shellfish. The

Table 1. Organizations, agreements, and frameworks, with an active role in the Black Sea

\begin{tabular}{lll}
\hline Body & Mandate & Black Sea Contracting Parties \\
\hline $\begin{array}{l}\text { Agreement on the Conservation of Cetaceans of the } \\
\text { Black Sea, Mediterranean Sea, and contiguous Atlantic } \\
\text { area ACCOBAMS (established in 1996) }\end{array}$ & Protection of the cetaceans & $\begin{array}{l}\text { Turkey, Bulgaria, Romania, } \\
\text { Georgia and Ukraine }\end{array}$ \\
\hline $\begin{array}{l}\text { Convention on the Conservation of Migratory Species } \\
\text { of Wild Animals } \\
\text { CMS (established in 1979) }\end{array}$ & $\begin{array}{l}\text { Conservation and sustainable use } \\
\text { of migratory animals and their } \\
\text { habitats }\end{array}$ & $\begin{array}{l}\text { Bulgaria, Romania, Georgia and } \\
\text { Ukraine }\end{array}$ \\
\hline $\begin{array}{l}\text { Commission on the Protection of the Black Sea Against } \\
\text { Pollution BSC (established in 1992) }\end{array}$ & $\begin{array}{l}\text { Combating pollution, management } \\
\text { of marine living resources pursuing } \\
\text { sustainable development }\end{array}$ & $\begin{array}{l}\text { Bulgaria, Georgia, Romania, } \\
\text { Russian Federation, Turkey and } \\
\text { Ukraine }\end{array}$ \\
\hline $\begin{array}{l}\text { Organization of the Black Sea Economic Cooperation } \\
\text { BSEC (established in 1999) }\end{array}$ & $\begin{array}{l}\text { Multilateral political and economic } \\
\text { initiatives aimed at fostering } \\
\text { interaction and harmony among its } \\
\text { members }\end{array}$ & $\begin{array}{l}\text { Bulgaria, Georgia, Moldova, } \\
\text { Romania, Russian Federation, } \\
\text { Turkey and Ukraine }\end{array}$ \\
\hline European Commission EC (established in 1967) & $\begin{array}{l}\text { Strengthen regional cooperation } \\
\text { through projects and tools (Black } \\
\text { Sea Synergy policy framework) }\end{array}$ & Bulgaria and Romania \\
\hline $\begin{array}{l}\text { FAO General Fisheries Commission for the } \\
\text { Mediterranean } \\
\text { GFCM (established in 1949) }\end{array}$ & $\begin{array}{l}\text { sustainable use of marine living } \\
\text { resources, at the biological, social, } \\
\text { economic and environmental level }\end{array}$ & $\begin{array}{l}\text { Bulgaria, Romania and Turkey, } \\
\text { Georgia and Ukraine }\end{array}$ \\
\hline
\end{tabular}


evaluation of these parameters is essential in establishing the aquaculture development potential of any region. The Black Sea is a heterogeneous water body with marked differences between geographical areas. It is also characterised by vast fluctuations in environmental factors; thus, it can be considered a challenging environment for most mariculture pursuits.

Being a large and diverse environment, the Black Sea offers different degrees of suitability for aquaculture development, and this is reflected in the way the aquaculture industry has developed in the different riparian countries. In its north-western portion, the shoreline is rather smooth, with few areas sheltered enough to allow for the development of large aquaculture activities. On its south and eastern shores (Turkish coast) instead, aquaculture farms are clustered in a few partially sheltered areas such as Kefken, Sinop, Ordu-Persembe, Trabzon-Yomra and Rize as these areas offer protection from the prevailing winds and the highest waves (Alkan et al., 2006; Akbulut et al., 2009a).

Following a detailed look at the environmental factors that most strongly influence aquaculture site suitability, paired with the use of the "Protocol for identifying suitable sites for mariculture" adopted by the Advisory Council for Mariculture in Spain (AguadoGiménez, 2012; Zaharia et al., 2017) as a guide, some differences in site suitability can be identified among the north-western and south-eastern coasts of the Black Sea (Table 2)

The information presented in Table 2 shows that the marked difference between the two areas is related to water depth and dissolved oxygen, while the other parameters considered are comparable. Thus, on the north-western Black Sea coast, the conditions for practicing open sea aquaculture are not quite ideal, but most of the parameters considered fall within the "moderate" (yellow) classification, which demonstrates the viability of aquaculture activity. The main limiting factors identified are the lack of sheltered areas, frequent storms and low temperatures in winter, which can endanger the harvest.

Despite these drawbacks, there was a mussel farm, successfully operating to produce and market around 5 tonnes of mussels every year. Unfortunately, in 2016, the farm was closed due to the following legislative drawbacks: 1) the absence of a microbiological classification of shellfish areas in Romania, and 2) the, the unclear situation of the water concession law (Niță et al., 2020). This situation emphasizes that as a result of the potential interactions between mariculture and other uses of the maritime space, zoning is essential. No actual allocated zones for aquaculture (AZA) are designated yet on the north-western shelf of the Black Sea, but a pre-selection of such a zone was made taking into account a series of parameters to indicate their suitability for aquaculture, based on the degree of compatibility (Niță et al., 2020).

In the south-eastern part of the Black Sea, mainly on the Turkish coast (which abounds in floating cages for European seabass, Rainbow trout and Black Sea trout) consist of more developed aquaculture activity. The situation in this area is quite different and in addition to better environmental conditions, several factors such as the involvement of the private sector, authorities and research sector have contributed to the development of the industry. An increase in the scale of aquaculture activities, particularly open cage systems, often generates concerns linked to negative environmental impacts. It has been demonstrated that an increase of dissolved and particulate nutrients in the water column as a result of uneaten feed particles and/or excreta, can often lead to localized deterioration in water and

Table 2. Black Sea environmental conditions as related to the protocol for identifying suitable sites for mariculture*

\begin{tabular}{l|c|c|c|c|c}
\hline Factor & Good & Moderate & Bad & N-W shelf & S-E shelf \\
\hline Exposure & partial & sheltered & exposed & exposed & exposed \\
\hline Waves & $\leq 1 \mathrm{~m}$ & 1 to $3 \mathrm{~m}$ & $\geq 3 \mathrm{~m}$ & $>3 \mathrm{~m}$ & $>3 \mathrm{~m}$ \\
\hline Water depth & $>30 \mathrm{~m}$ & 15 to $30 \mathrm{~m}$ & $<15 \mathrm{~m}$ & $\geq 15 \mathrm{~m}$ & $>30 \mathrm{~m}$ \\
\hline Currents & strong & moderate & low & strong & low \\
\hline Pollution & absent & low & high & low & 24 to $27^{\circ} \mathrm{C}$ \\
\hline Temp. max. & 22 to $24^{\circ} \mathrm{C}$ & 24 to $27^{\circ} \mathrm{C}$ & $>27^{\circ} \mathrm{C}$ & 24 to $27^{\circ} \mathrm{C}$ & $<8^{\circ} \mathrm{C}$ \\
\hline Temp. min. & $12^{\circ} \mathrm{C}$ & $10^{\circ} \mathrm{C}$ & $<8^{\circ} \mathrm{C}$ & $<8^{\circ} \mathrm{C}$ & 15 to 19 PSU \\
\hline Mean salinity & 25 to $35 \mathrm{PSU}$ & 15 to $25 \mathrm{PSU}$ & $<15 \mathrm{PSU}$ & 15 to $19 \mathrm{PSU}$ & $<5$ \\
\hline Salinity oscillations & $<5$ & 5 to 10 & $>10$ & $<5$ (southern RO, & BG) \\
\hline $\begin{array}{l}\text { Dissolved oxygen } \\
\text { (\%) }\end{array}$ & $>100$ & 70 to 100 & $<70$ & 70 to 100 & $>100$ (95 to 110$)$ \\
\hline $\begin{array}{l}\text { Seabed topography } \\
\text { (\%) }\end{array}$ & $>30$ & 10 to 30 & $<10$ & 5 - 20 & 10 to 30 \\
\hline Substrate & sand & mixed & mud & sand, rock, mud & mixed \\
\hline Trophic status & oligotrophic & mesotrophic & eutrophic & $\begin{array}{c}\text { eutrophic to } \\
\text { mesotrophic }\end{array}$ & mesotrophic \\
\hline Fouling & low & moderate & high & moderate & moderate \\
\hline Predators & absent & rare & abundant & rare & rare \\
\hline
\end{tabular}


sediment quality in the proximity of aquaculture sites (Price et al., 2015). Nonetheless, these impacts are often dependant of local hydrodynamic conditions and feed management strategies, thus impacts cannot be assumed. Specific studies to the areas discussed here have been performed over a number of years to evaluate potential negative impacts to the local ecosystems. Data from several studies concur to indicate that only moderate disturbances consistent with organic enrichment of the sediment and with no major long-term intense pollution can be identified at the studied sites (Telli-Karakoç et al., 2008; Telli-Karakoç et al., 2010). Therefore, research so far conducted in the areas of interest have concluded that existing fish farms located in the Turkish coast do not pose a major threat to local benthic fauna (Bascinar et al., 2014). Furthermore, the observed nutrient concentrations in the water column do not appear to have a limiting effect on phytoplankton growth and zooplankton development (Telli-Karakoç et al., 2010).

Overall, there is great potential for a growing aquaculture pursuit in the Black Sea, on the one hand by adapting its development to the specificities of the two different coasts: the shallow, unsheltered and highly variable (in terms of salinity and temperature) northwestern shelf and the deep, more sheltered and stable south-eastern shelf. Moreover, by fostering participatory processes of authorities, investors and research aiming at settling the most "sensitive" issues related to marine aquaculture (environmental footprint, AZA, legislation), this endeavour can thrive around the Black Sea basin.

\subsection{Allocation of Zones for Aquaculture Within the Marine Spatial Planning Framework}

\subsubsection{Identify Suitable Areas for Aquaculture in the Black Sea}

In light of the environmental conditions discussed, there are several areas that are less adapted for coastal aquaculture development and, hence, finding suitable areas for establishing farms is important. The expansion of aquaculture requires adequate space to implement its facilities in coastal areas, and the need to better integrate aquaculture with other sectors to minimize conflicts has been acknowledged for a long time (FAO, 2013). Due to the increasing complexity and demand for maritime areas, some common strategies and approaches have been developed to manage more coherently coastal activities and resources, including aquaculture, fisheries, tourism, and energy, among others. In this sense, the European Parliament and the Council adopted a legislation to create a common framework for Maritime Spatial Planning (MSP) in Europe (Directive 2014/89/EU). MSP is being used and applied to guarantee the development of different activities and resources, integrating multiple objectives in a coordinated way. According to the United Nations
Educational, Scientific and Cultural Organization (UNESCO), MSP can be defined as "a public and political process where the marine space is allocated, and human activities are distributed in order to achieve ecological, economic, and social objectives that are usually specified through a political process" (Ehler \& Douvere, 2009). MSP processes need to be highly flexible and adaptable to local conditions according to the scale of the marine area in which the development objectives need to be achieved (Meaden et al., 2016). Furthermore, attention was also given to aquaculture in the Guidelines on Integrated Coastal Zone Management (ICZM) in the Black Sea and suggested to "take into account the need to protect finfish and shellfish aquaculture areas undergoing development". Spatial planning for aquaculture, as well as the layout of aquaculture management areas, should consider the balance between the social, economic, environmental and governance objectives of local communities and responsible development (Aguilar-Manjarrez et al., 2017).

In order to progress towards effective management of aquaculture activities in the Mediterranean and Black Sea, the General Fisheries Commission for the Mediterranean (GFCM) adopted a specific Resolution (GFCM/36/2012/1) on guidelines for allocated zones for aquaculture (AZA). AZA's framework is considered a key planning tool, aiming at promoting better governance of aquaculture development in line with an ecosystem approach to aquaculture (EAA), ICZM, and MSP approaches (Massa et al., 2017). Moreover, the adoption and implementation of the AZA framework will improve the integration with other coastal activities, thus preventing conflicts among coastal users. This cross-border and cross-sector tool enables the framing of aquaculture activities within MSP and involves the coordination among different authorities and stakeholders (Sanchez et al., 2016; Macias et al., 2019; Fourdain et al., 2019).

\subsubsection{Spatial Planning in the BS and Aquaculture Development}

Several initiatives related to MSP and aquaculture have been implemented in the Black Sea region. These initiatives are aimed at developing tools to assess the interactions between different users, in line with the blue growth approach to protect living aquatic resources and create an enabling environment for sustainable development (European Commission, 2020). Furthermore, significant progress has been made in collecting and mapping data on human activities at sea, through specific platforms and portals.

In this sense, the EU-MC project SIMSEA (20152017) implemented an advanced marine modelling to simulate the complex Black Sea ecosystem. This model has been started to validate the General Estuarine Transport Model (GETM) for Black Sea's simulations. The model is run with atmospheric data from the 
European Regional Downscaling Experiment (EUROCORDEX), river runoff from Global Runoff Data Centre (GRDC) and was prepared with both temperature and salinity $3 D$ fields resulted from the project MEDAR/MEDATLAS II (Miladinova et al., 2016). In this context, it is worth mentioning that Bulgaria and Romania implemented the Cross-border Maritime Spatial Plan for Black Sea (MARSPLAN-BS) to support the implementation of the MSP Directive 2014/89/EU while ensuring an institutional framework and consolidating the cross-border cooperation between the two countries. In addition, both countries started MARSPLAN-BS II in 2019 to continue supporting MSP implementation through common methodologies and geographic information system (GIS) database. Other recent EU funded initiatives strongly focused on the use and development of specific GIS applications to spatial planning issues within MSP and ICZM (i.e. PlanCoast, PEGASO, ECOAST and MARSEA) while improving the availability of environmental data to assess the state of the Black Sea and increase protected areas (i.e. MISIS). Another EU funded project targeting the blue growth initiative, named Black Sea CONNECT, was also launched in 2019 to develop a new Strategic Research and Innovation Agenda (SRIA) and to foster human and infrastructure capacity building in the coastal and maritime sectors. Within these initiatives, aquaculture development represents one of the main topics addressed as a consequence of its complex interactions with other coastal users and the environment.

Progress has been made in the Black Sea riparian countries to develop and adopt a strategic plan for aquaculture development. Table 3 illustrates the current aquaculture development regulatory framework and whether AZA principles have been taken up and implemented in these countries. From this analysis, it is clear that although all countries have a specific or shared legislation, not all considered or implemented specific provisions on AZA in their national aquaculture development strategies. In more detail, Turkey, Russian Federation and Ukraine have specific regulation for aquaculture while Georgia and Romania have a shared legislation on aquaculture and capture fisheries. Furthermore, Turkey and Russian Federation consider aquaculture zoning in their national strategies and Romania already indicated the potential benefits of AZA application for mussel farming (Niţă et al., 2019) and some efforts on its implementation are ongoing (Niţă et al., 2021). Finally, only Russian Federation counts with a formal consultation process with relevant multi-stakeholders' platform in spatial planning for aquaculture.

A common governance process supported by shared regulatory frameworks, in which the implementation of aquaculture zoning process is clearly embedded, would facilitate the sustainable development of aquaculture in the Black Sea, as indicated by the FAO-GFCM Strategy for the sustainable development of Mediterranean and Black Sea aquaculture (FAO, 2018c), which resulted from a wide participatory process with the involvement of all countries and stakeholders.

\subsection{Overview of Aquaculture Production Trends in the Bordering Countries}

The aquaculture industry in the countries bordering the Black Sea encompasses five different FAO statistical areas: Europe, inland waters (area 05), Mediterranean, and Black Sea (area 37); Asia Inland waters (area 07); Pacific, Northwest (area 61) -Only for the Russian Federation-, and Atlantic, Northwest (area 27) -Updated in May 2021-. Between 2001 and 2018, aquaculture production in the Black Sea Countries rose from 202,566 tonnes in 2001 to 565,330 tonnes, representing $179 \%$ increase, with an average annual growth rate of $5.9 \%$. This rate is higher than the value of the global aquaculture production of farmed aquatic animals reported by $\mathrm{FAO}$ at $5.3 \%$ per year for the same period (FAO, 2020c). If the contribution of aquaculture to the national and local economies is considered, the production value more than quadrupled from 485,369 USD in 2001 to 2,050,335 UDS in 2018 (FAO, 2020c).

Table 3. Status of Black Sea riparian countries on the implementation and monitoring of the GFCM strategy for the sustainable development of Mediterranean and Black Sea aquaculture* in 2019.

\begin{tabular}{|c|c|c|c|}
\hline Black Sea riparian countries & $\begin{array}{l}\text { Existence of specific and } \\
\text { sufficiently comprehensive } \\
\text { regulation(s) on } \\
\text { aquaculture }\end{array}$ & $\begin{array}{l}\text { Existence of specific provision on AZA } \\
\text { (or aquaculture management areas } \\
\text { or aquaculture zoning) in national } \\
\text { aquaculture strategies or plans }\end{array}$ & $\begin{array}{l}\text { Existence of a formal process } \\
\text { to consult with stakeholders } \\
\text { for one or more steps in } \\
\text { aquaculture spatial planning }\end{array}$ \\
\hline Bulgaria** & $\begin{array}{l}\text { Legislation shared with } \\
\text { capture fisheries }\end{array}$ & ( & YES \\
\hline Georgia & $\begin{array}{l}\text { Legislation shared with } \\
\text { capture fisheries }\end{array}$ & AZA not yet considered & NO \\
\hline Romania & $\begin{array}{l}\text { Legislation shared with } \\
\text { capture fisheries }\end{array}$ & AZA not yet considered & NO \\
\hline Russian Federation & Specific for aquaculture & Aquaculture zoning considered & YES \\
\hline Turkey & Specific for aquaculture & Aquaculture zoning considered & $\mathrm{n} / \mathrm{a}$ \\
\hline Ukraine & Specific for aquaculture & AZA not yet considered & NO \\
\hline
\end{tabular}


Despite the great diversity in farmed species, which in 2018 included 56 species of which 50 finfish and 6 invertebrates (FAO, 2020c), growth is vastly dominated by the farming of two main finfish species: the rainbow trout (Oncorhynchus mykiss) and the European seabass (Dicentrarchus labrax) (Figure 1), representing 27.6 and $20.7 \%$, respectively, of the total production in 2018 (FAO, 2020c).

Overall, only seven species (Table 4) represented the vast majority of the countries' combined production in 2018. Aside from Seabass and Rainbow Trout, the other main species reared in the region were the common carp (Cyprinus carpio) for about $15.4 \%$ of the total production, the gilthead seabream (Sparus aurata), with 13.6\%, the silver carp (Hypophthalmichthys molitrix), with $8.5 \%$, the Atlantic salmon (Salmo salar), with $3.6 \%$, and the grass carp (Ctenopharyngodon idella), representing $1.6 \%$.

Significant differences exist in terms of production systems and overall industry development between countries which is clearly reflected in each country's production output. Indeed, overall production outputs are not homogenous among countries with $91.7 \%$ of the volume being produced by the Russian Federation and Turkey (36.3\% and 55.4\%, respectively). Equally, different countries have focused on the production of different species: Rainbow trout was mainly farmed in Turkey (71.0\%), Russian Federation (22.5\%), and Bulgaria (3.8\%); European seabass and gilthead seabream were cultivated only in Turkey, and the leading producers for the common and silver carp are Russian Federation and Ukraine, with $78.5 \%$ and $10.3 \%$, respectively.

Focusing the attention only to the Black Sea, in 2018 marine aquaculture production accounted for 17,808 tonnes, representing only $3.2 \%$ of the countries' global aquaculture production. This volume is mainly represented by finfish such as rainbow trout for 9,335 tonnes, European seabass for 3,647 tonnes and 375 tonnes of salmon farmed in Turkey, and around 100 tonnes of rainbow trout also farmed in Georgia. Concerning mussels, the production reached 2,531 tonnes in Bulgaria, while the Russian Federation also produced 848 tonnes of cupped oyster and 540 tonnes of mussels (FAO, 2020c).

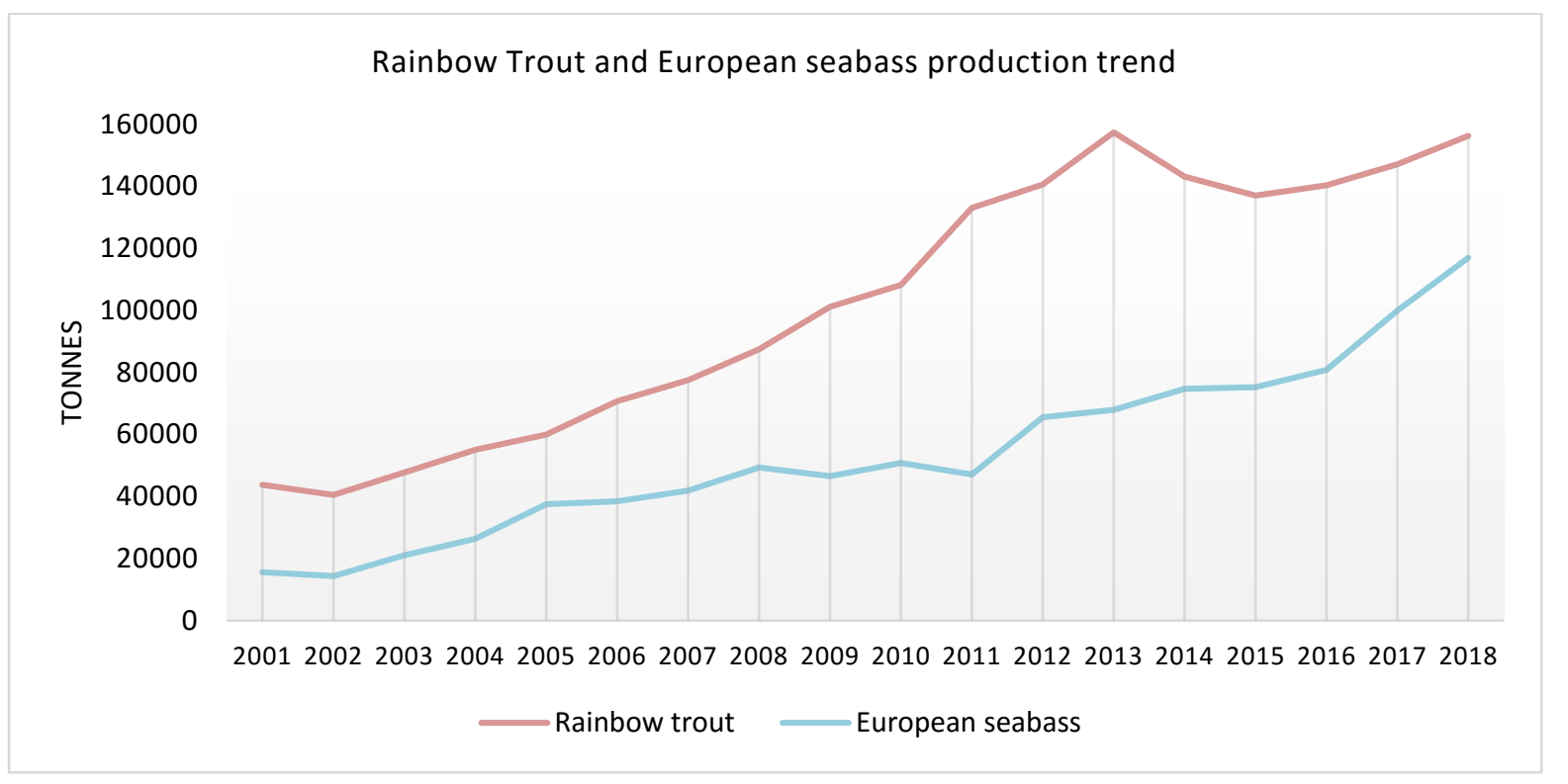

Figure 1. Production trend of the two main species reared in the Black Sea bordering countries (2001-2018)

Table 4. Aquaculture production (in tonnes) of the seven main species reared in the Black Sea bordering countries (2015-2018)

\begin{tabular}{lllcccc}
\hline Species & FAO major fishing area & Environment & $\mathbf{2 0 1 5}$ & $\mathbf{2 0 1 6}$ & $\mathbf{2 0 1 7}$ & $\mathbf{2 0 1 8}$ \\
\hline Atlantic salmon & Atlantic, Northeast & Marine & 10,834 & 12,857 & 13,016 & 20,566 \\
\hline Common carp & Inland waters & Freshwater & 75,416 & 80,453 & 83,584 & 86,976 \\
\hline \multirow{2}{*}{ European seabass } & $\begin{array}{l}\text { Mediterranean and } \\
\text { Black Sea }\end{array}$ & Marine & 75,164 & 80,847 & 99,971 & 116,915 \\
\hline \multirow{2}{*}{ Gilthead seabream } & $\begin{array}{l}\text { Mediterranean and } \\
\text { Black Sea }\end{array}$ & Marine & 51,844 & 58,254 & 61,090 & 76,680 \\
\hline Grass carp & Inland waters & Freshwater & 18,860 & 6,665 & 8,968 & 9,266 \\
\hline \multirow{2}{*}{ Rainbow trout } & Inland waters & Freshwater & 130,738 & 135,565 & 142,063 & 146,953 \\
\cline { 2 - 7 } & $\begin{array}{l}\text { Mediterranean and } \\
\text { Black Sea }\end{array}$ & Marine & 6,187 & 4,703 & 5,052 & 9,335 \\
\hline Silver carp & Inland waters & Freshwater & 33,373 & 50,344 & 49,532 & 47,744 \\
\hline
\end{tabular}




\subsection{Overview of Aquaculture Products Markets and the Need to Boost Countries Self-sufficiency Rates}

The marketability of aquaculture products is one of the main drivers of aquaculture development. The Black Sea possesses great potential in terms of marine resources within the Blue Economy concept. The FAO GFCM and European Commission (EC) have underlined the potential of sustainable aquaculture as a major source of food and income for the Black Sea in "Sofia Ministerial Declaration" (EC, 2018). Nevertheless, market acceptance and seafood marketing strategies, either wild or farmed products, are becoming increasingly global, complex and competitive. The scenario of today's markets for aquatic products include the globalization of the seafood trade that has exacerbated the market competition among producers, increasing consolidation and market power in the retailing sector, the rearrangement in distribution channels along the value chain. Furthermore, there are more rigid standards for handling and food safety by retailers, while consumers increasingly request for seafood safety and quality, accessibility and traceability.

Within this context, aquaculture management and development policies call for a better understanding of market dynamics through market studies covering the analysis of both supply and demand. This section summarizes some general aspects of markets for aquatic products in the Black Sea region e.g., trade balance, domestic consumption of seafood and selfsufficiency rates for aquatic products. The objective is to shed light on challenges and opportunities for development of a market-oriented aquaculture and efficient value chains within the blue growth perspective.

\subsubsection{Trade Balance}

Trade balances for wild \& farmed aquatic products in Black Sea countries are presented in Table 5. In 2018, Russian Federation, Turkey and Georgia (with relatively small surplus in 2018) were net exporters, while Bulgaria, Romania and Ukraine had trade deficit in terms of aquatic products. This trade deficit is highly evident in Romania and Ukraine.

In terms of product categories, finfish, molluscs, crustaceans and other invertebrates are the most widely traded products among the Black Sea countries.

\subsubsection{Domestic Consumption}

Based on data spanning the decade 2009-2018 (Figure 2), Russian Federation shows the highest average apparent per capita domestic consumption of aquatic products among the Black Sea countries (24.7 $\mathrm{kg})$, while Romania shows the lowest $(5.4 \mathrm{~kg})$.

Table 5. Trade Balance for aquatic Products in Black Sea Countries (2018, In net weight)

\begin{tabular}{lccc}
\hline Country & Export (Tonnes) & Import (Tonnes) & Trade Balance (Tonnes) \\
\hline Bulgaria & 18680 & 46854 & -28174 \\
Georgia & 19567 & 17168 & 2399 \\
Romania & 5134 & 110895 & -105761 \\
Russian Federation & 2330007 & 607307 & 1722700 \\
Turkey & 177500 & 98315 & 79185 \\
Ukraine & 10595 & 380570 & -369975 \\
\hline
\end{tabular}

(Source: FAO, 2020b; FAO, 2020c; Turkish Ministry of Agriculture and Forestry, 2020)

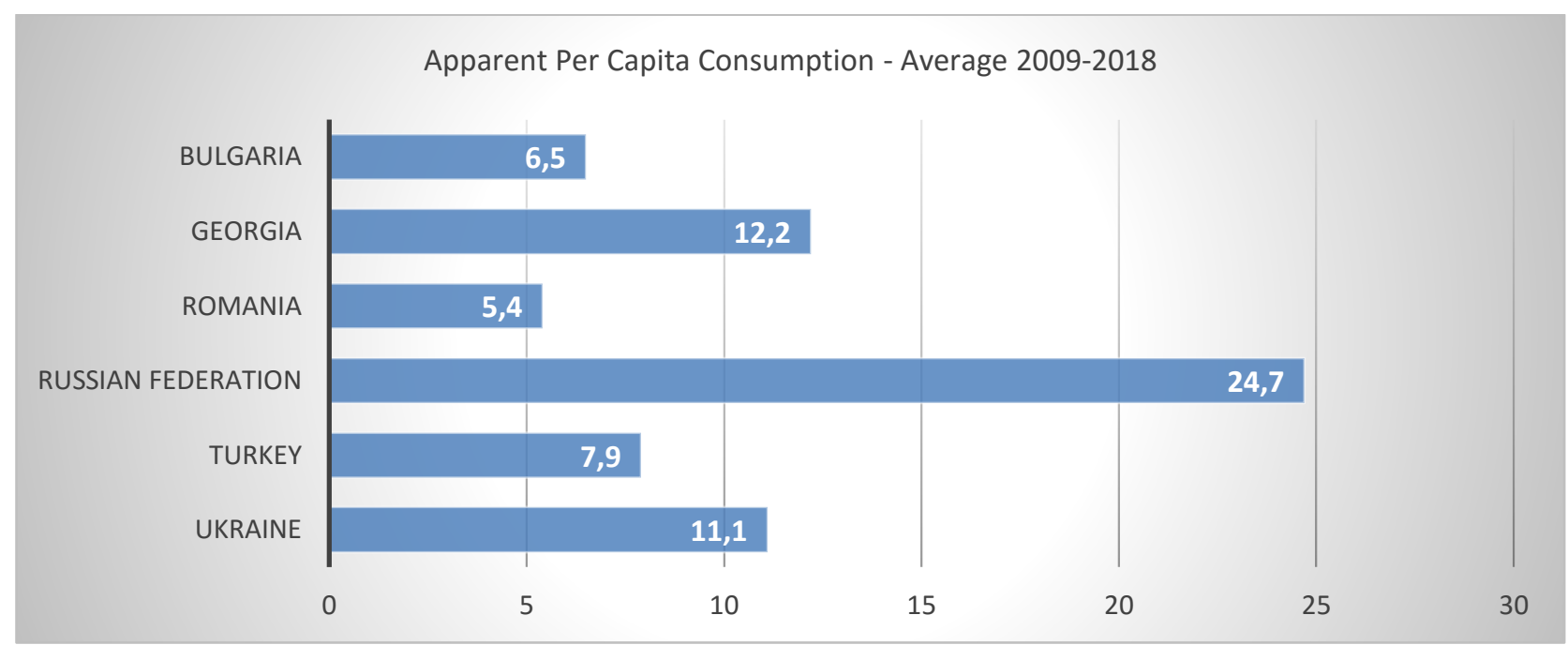

Figure 2: Average 2009-2018 Apparent per capita domestic consumption of aquatic products in Black Sea countries (Source: FAO, 2020b; FAO, 2020c; Turkish Ministry of Agriculture and Forestry, 2020) 
Considering that the global per capita consumption of aquatic products in 2018 was $20.5 \mathrm{~kg}$ (FAO, 2020a), the domestic consumption of aquatic products among the Black Sea countries are below world average.

\subsubsection{Self-sufficiency Rate for Aquatic Products}

Self-sufficiency rate indicates the ability of a country to meet the domestic consumption by domestic supply of aquatic products (wild \& farmed). SelfSufficiency rates for aquatic products in Black Sea countries are given in Figure 3 and are based on the average data spanning the decade 2009-2018. Being net exporters of aquatic products, self-sufficiency rates are high for the Russian Federation and Turkey. Selfsufficiency rates for Bulgaria, Romania and Ukraine are low, revealing that these countries are highly dependent on imports of aquatic products to meet their domestic consumption. On the contrary, Georgia is in a much better position with a self-sufficiency rate of $92 \%$.

Development of aquaculture in the Black Sea would not only contribute to decreasing the fishing pressure on fish stocks but would also generate jobs and income for the local communities. Such development in the region is not evenly spread and there is a need for knowledge exchange and regional cooperation (EU, 2019). Development of aquaculture in the region would also help countries to decrease their dependency on imports of aquatic products and boost their selfsufficiency rates. This needs to be supported by national policies to boost the domestic consumption of aquatic products to avoid unbalanced supply and demand patterns. National aquaculture development policies targeting all nodes of the value chain (VC) including VC key factors such as fish farmers, processors, wholesalers/exporters, retailers and consumers and service providers such as suppliers of farming equipment, aqua-feed, egg/fry, financers, transportation/logistics and certification bodies, would facilitate a more harmonious development of sustainable aquaculture in the region. The establishment of the GFCM "Aquaculture Demonstrative Centers" and foreseen "Market Observatories" in the Black Sea region are valuable platforms for regional scientific and technical cooperation as well as stakeholder consultations.

\section{A Closer Look at Aquaculture Success Stories in the Black Sea Riparian Countries}

\subsection{Aquaculture in Bulgaria: Traditions and Modernity}

\subsubsection{Social, Economic and Environmental Considerations for Aquaculture}

Aquaculture in Bulgaria is defined by the influence of a complex system of social, economic and other factors. In the national economy, aquaculture is not a key sector, but it is extremely important for the livelihood of the rural communities and developing areas. Regarding financial assistance, the Bulgarian Development Bank (BDB) offers low-interest loans for aquaculture under certain requirements. Other funding sources include commercial banks and European Funds. Bulgaria most important natural resources are its diverse climate, abundant supplies of suitable fresh, brackish and marine water. These resources are the suitable prerequisites for the development of aquaculture activities. Owing to the wide variety of natural resources, farmers have the potential to grow any aquaculture species and possess a huge potential for mariculture development. Despite this, it is traditional pond fish farming methods that are currently used, and carp culture makes up for most of the total production by volume.

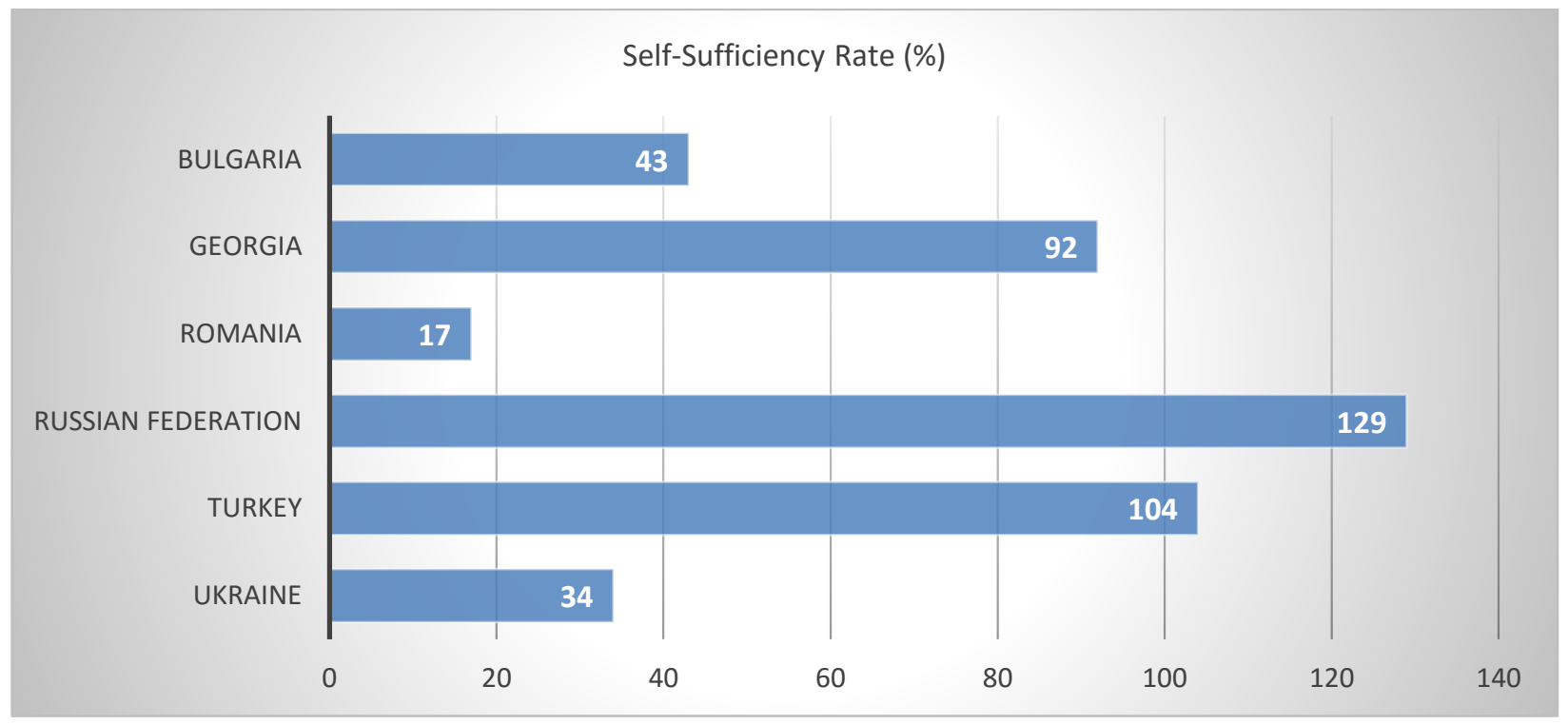

Figure 3: Average 2009-2018 Self-sufficiency rate for aquatic products in Black Sea countries. (Source: FAO, 2020b; FAO, 2020c; Turkish Ministry of Agriculture and Forestry, 2020) 


\subsubsection{Education, Research, Training and Industry Development}

Fisheries and aquaculture educational activities are carried out in two accredited government Bulgarian universities: Sofia University "Kliment Ohridski" and Trakia University. They offer training and education in Bachelor's, Master's and Doctor's degrees and a professional qualification "Aquaculture Technologist". The scientific research centres related to the aquaculture sector in Bulgaria are institutes of the Agriculture Academy and Bulgarian Academy of Sciences, as well as the National Veterinary Institute for Research and Diagnostic Activities within the National Veterinary Service of the Ministry of Agriculture. The Institute of Fish Resources (IFR), the Agricultural Academy and the Institute of Oceanology "Fridtjof Nansen", Bulgarian Academy of Sciences (IO-BAS) in Varna are those mainly engaged in scientific research activities related to sustainable exploitation of fish and other aquatic resources in the Black Sea. Most of the innovative technologies applied to Bulgarian mariculture sector were developed at The Institute of Fish Resources in Varna during the 70s', including the development of first mussel farms and marine net cage culture of sea trout. The Institute of Fisheries and Aquaculture (IFA), Agricultural Academy in Plovdiv, carries out scientific and research activity in the aquaculture field, particularly in the development of new production methods for commercially important freshwater species, as well as opportunities for their introduction into the country.

\subsubsection{General Policies: Structure and Organization of the Aquaculture Sector}

The Executive Agency of Fisheries and Aquaculture (EAFA), which was established within the Ministry of Agriculture and Food (MAFF), is the executive body of the central administration for implementation of the national policy on fishery and aquaculture. This structure applies the fisheries legislation and coordinates the development of fisheries and aquaculture, the handling of fishing licenses and authorizations, registration of aquaculture enterprises, first sale auctions and registered buyers, verification and confirmation of catch certificates at import/export of fishery products, distribution of quotas for fish and other aquatic species, conservation of fish stocks and enforcement of fisheries regulations. The Maritime Affairs and Fisheries Directorate has been opened the Ministry of Agriculture and Food, which is the managing authority of the Operational Programme "Maritime Affairs and Fisheries" (2014-2020). The programme is funded by the European Maritime and Fisheries Fund (EMFF). The directorate organizes, coordinates and participates in the preparation, updating, implementation, monitoring and evaluation of the national fishery and aquaculture programme.
The number of active registered aquaculture producers continues to increase in connection with the ban on commercial fishing in inland waters, which came into force in August, 2012. Aquaculture production is expected to decrease in 2021-2022, as fisheries and aquaculture are among the sectors most directly affected by the Covid19 crisis. According to EAFA data, there is a significant decline in the production and sales of fish and other aquatic organisms (about 25\%) for the period from March to the end of 2020 (EAFA, 2020; MAFF, 2020).

\subsubsection{Sector Size, Farming Systems, Species and Production Technologies}

The average total value of aquaculture products in Bulgaria for the period 2007-2019 was 26.226 million euros, and on average 648 workers were employed in the industry each year (IRA-STRATEGMA 2020). In the same period the number of registered aquaculture farms had steadily grown, almost tripling its number to 700 farms in 2019 (MAFF, 2020).

Fish farming activities started in the late $19^{\text {th }}$ century with the establishment of carp breeding farms in Ruse (Obraztsov Chiflik villages) and Sadovo (Klisarova et al., 2020). However, despite financial support from the state, fish farming did not develop commercially until the late forties. After 1950, the rapid development of carp farming began and in 1965 it reached an extension of 16,000 hectares. With the development of the aqua feed industry and the use of granulated feeds, the yield also increased significantly (IRA-STRATEGMA, 2020).

In 1978, the Council of Ministers adopted a targeted programme for the development of freshwater fish farming, which provided for the production of freshwater fish in 1980 to reach 16,000 tonnes, and in 1985 35,000 tonnes. Common carp (Cyprinus carpio) is the main freshwater species $(40.4 \%$ of the output of Bulgarian aquaculture production) cultivated in Bulgaria today. They are reared either in ponds or in net cages in mono and polyculture systems. In polyculture, the main species reared with common carp are silver carp (Hypophthalmichthys molitrix) and bighead carp (Hypophthalmychthys nobilis). Rainbow trout (Oncorhynchus mykiss) accounts for about $27.1 \%$ of total aquaculture output.

More recently, Bulgaria exports fish and fishery products that in 2019 amounted at 15,890 tonnes, of which $78.7 \%$ to the European market and $21.3 \%$ outside of Europe (21.3\%) (MAFF, 2020), and including nearly half of the carp and one-third of the trout production (IRA-STRATEGMA, 2020). During the last thirty years in the country there have been no selective breeding programmes, broodstock are normally of unclear origin and no new breeds were created, leading to inbreeding and lower production efficiency. The lack of a long-term plan for maintenance and restocking of the native species does not allow the organization of sustainable 
and scientifically planned production. Economic constraints normally limit the sustainable operation of specialized centres for reproduction of selected stocks. Nonetheless, such production currently exists for trout, but it lacks scientific basis leading to the delivery poor results. It is, therefore, advisable that fish producers should try to consolidate into breeder associations and agree upon common quality standards. It would be useful for EU financing of aquaculture projects to focus not only on production but also on the setting-up of extension services or demonstration centres to assist aquaculture farmers to improve farming methods and techniques, through dedicated professional development activities, which could ultimately lead to increased production efficiency and income.

\subsubsection{Shellfish Farming}

Bulgaria is a pioneer in the industrial cultivation of mussels in the Black Sea, and in the period before 1989 the country delivered to the market approximately 150 tonnes of mussels per year (FAO, 2020c). Since 2008, Bulgaria is the most important supplier of mussels in the Black Sea region and in 2018 the production reached over 2,531 tonnes. Until 2020, the only species grown in marine aquaculture remains the Mediterranean mussel (Mytilus galloprovincialis) that is farmed by surface culture systems (i.e. long lines with droppers or continuous rope), and underwater facilities to prevent negative effects of waves and storms (construction of collectors from the bottom up, below water surface (3-4 m)) (Klisarova et al., 2020). Other species of interests for the market are Chamelea gallina, Donax trunculus, Mya arenaria and the invasive species rapana (Rapana venosa), currently only fished while culture methods are being developed. To achieve more sustainable results and to increase market potential, it is advisable for the mussel farmers to be integrated with the food and restaurant industry. The national producers should focus on value adding activities such as long term storage, processing and marketing of mussel products to add more promising within the export markets. Finally, potential candidate species for aquaculture could include finfish species (turbot, seabass and seabream), crustaceans, seaweed and microalgae (MAFF, 2014).

\subsection{Status and Opportunities of Aquaculture in Georgia}

Georgia features a coastline of $310 \mathrm{~km}$ on the Black Sea and is rich in inland water resources which include several thousand rivers and streams with an estimated total length of $5,000 \mathrm{~km}$, about 860 lakes (total area of almost $16,900 \mathrm{ha}), 1,296 \mathrm{~km}$ of irrigation canals and 23,000 ha of water reservoirs (FAO, 2015).

In terms of fish, Georgia hosts 75 marine and 68 freshwater species including several highly valued and endangered ones (Khavtasi et al., 2010). Among freshwater fish, it is worth mentioning the sturgeons of which the following seven species are considered endangered: Acipenser guldenstaedtii colchicus, Acipenser nudiventris, Acipenser stellatus, Acipenser sturio and Huso huso (Khavtasi et al., 2010). Highly valued fish species include also the Black Sea salmon (Salmo labrax), as well as some local and introduced species (Khavtasi et al., 2010). For the latter, in 19761978 the channel catfish Ictalurus punctatus was first introduced in Georgia and studies for its acclimation and farming were undertaken (Goradze et al., 2013).

Aquaculture in Georgia was well established in the 1950s, but the number of farms has been diminishing since early 1990' and in 2015 there were about 40 operating fish farms with a total area of 2,450 ha (FAO, 2015). Despite this, aquaculture production in Georgia gradually rose from 422 tonnes in 2008 to over 2,381 tonnes in 2018 (FAO, 2020c) of which the majority was within freshwater.

Cultured species are mainly limited to rainbow trout in flow-through systems on small-scale farms and culture-based inland cyprinid fisheries in ponds, lakes and reservoirs. Given the prevalence of freshwater aquaculture and trout farming, most of the trout eggs, fry and fingerlings for trout farm are produced in Georgia, while many other inputs such as fishmeal for the production of fish feed, are generally imported.

Although there are several issues to be addressed in the Georgian Black Sea coastal zone (Goradze et al., 2014), Georgia holds a great potential to further develop mariculture in cages as well as freshwater aquaculture that would considerably increase the volume of aquaculture products, contributing to meet market demands for fishery products as well as significantly reducing fishing pressure on marine fish stocks (Khavtasi et al., 2010).

Several priorities were identified for the Georgian sustainable aquaculture development (Khavtasi et al., 2010) including: (i) completion of a database of surface water resources, combined with the promotion of technical and environmental awareness, in order to enhance sustainable management; (ii) survey of fish farm facilities, combined with farmers meetings and short trainings; (iii) establishment of a reliable fish fry production network combined with privatized extension services; (iv) restoration of the sturgeon hatchery; (v) upgrading of the administrative and management structures; (vi) enhanced governance of the sector by the upgrading of Georgian fisheries laws and regulations.

According to Goradze et al. (2014), in 2004-2005 in cooperation with FAO, Georgia initiated a 15-year management plan for the development of the country's fishery economy with the purpose of creating the basis for an ecosystem approach towards fishery, and a law on "Fishery and Aquaculture" was also introduced. Furthermore, Sekhniashvili and Kathijotes (2018) report that the Ministry of Agriculture in 2015 had initiated a thorough study to understand the country's potential to 
develop aquaculture. Aquaculture development should be framed within the national legal context, especially for that concerning: allocation of space for aquaculture, environmental protection, food security, biosecurity control, and improved aquaculture management and technical skills.

\subsection{Romanian Aquaculture: from Research to Opportunities for Development}

Traditional Romanian aquaculture is based mainly on freshwater fish species. The expansion of global aquaculture in the 70s and severe flooding episodes in 1970 and 1975 persuaded Romanian authorities to strengthen fish farms and build new water retention capacity for flood prevention and aquaculture. Thus, by the end of the 80 's freshwater farmed fish production reached 50,680 tonnes (FAO, 2020c), a figure achieved neither before nor since. This level of production was due to an intense process of acclimatization for new species, especially the four Chinese carp species: silver carp (Hypophthalmichthys molitrix, Valenciennes, 1844), bighead carp (Hypophthalmichthys nobilis, Richardson, 1845), grass carp (Ctenopharyngodon idellus, Valenciennes, 1844) and black carp (Mylopharyngodon piceus, Richardson, 1846), carried out at the fish farming research institute in Nucet.

This work provided the technological background for farming common carp and associated species in polyculture pond systems to exploit the nutrients available in the different ecological niches. Around the same time, trout farms were developed on the slopes of the Carpathians. Political changes taking place in the last decade of the $20^{\text {th }}$ century caused the sector to shrink, a process that stopped only after the privatization process started in 2001. In 2019 the total available fish farming area for freshwater species was over 90,320 ha, most of them in the south-east, south and north-east. However, only around 60,000 ha were actually occupied by operational farming sites (ROMFISH, in preparation).

Although the traditional carp production model commonly practiced in Central and Eastern Europe has persisted in Romania, innovative approaches regarding species, farming environment, technology, and business models are currently being considered. More recently, carp farming maintains its traditional methods, while trying to improve its economic performance through innovative approaches. These include the diversification of activities to develop eco-tourism or introducing integrated multi-trophic cultivation using intensiveextensive combinations to make full use of the nutrient load of the water.

However, in recent years, mariculture has attracted increasing attention. In the 1980s research initiated to stimulate the sector focused on various invertebrates and finfish and led to some commercial production along the Romanian Black Sea coast.

From 1981 to 1985 , scientists at the Romanian Marine Research Institute, today the National Institute for Marine Research and Development "Grigore Antipa" (NIMRD), carried out the first experiments aimed at developing the technology to rear rainbow trout (Oncorhynchus mykiss Walbaum, 1792) in seawater (Ioniță et al., 1983; Zaharia et al., 2017). The research showed that it was possible to adapt rainbow trout to the conditions in the Black Sea, and that the fish registered a higher growth rate than in freshwater (Zaharia et al., 2017).

Invertebrate culture in the Romanian Black Sea began with crustaceans such as the grass shrimp (Palaemon adspersus, Rathke, 1837) (Porumb, 19992000). Onciu (1984) studied the nutrition of the shrimp larvae, while research by Dimoftache (1986) established a methodology for raising crustaceans in tanks, described their life cycle, and the duration of the development of larval stages. In 2004 and 2005, two successful experiments to establish methods and technologies for shrimp mariculture in the Romanian littoral zone were conducted and using rock shrimp (Palaemon elegans, Rathke, 1837) and grass shrimp (Zaharia et al., 2006; Zaharia et al., 2017).

In Romania, between 1997 and 1999, a mariculture project was carried out within the Environment Programme for the Black Sea (BSEP) and financed by PHARE (Poland and Hungary: Assistance for Restructuring their Economies). The project established a pilot hatchery at NIMRD Constanța to produce one million oyster juveniles per year to be used by local shellfish farmers. This was only partially achieved (Zaharia et al., 2017). Subsequently, from 2001 to 2003, within the project "Development of technologies for the reproduction and growth of Crassostrea gigas (Thunberg, 1793) at the Romanian coast" (funded by the Romanian Management Agency for Scientific Research, Innovation and Technology Transfer - Polytechnic Bucharest), experiments were carried out develop the technology for the breeding and grow out of Japanese oysters, in collaboration with a private company Maricultura Ltd. Adapted to the conditions of the Romanian coast, following the experiments and pilot production, the long-line system proved to be the most suitable for oyster culture. At the end of 2002, the first oysters were supplied to the Romanian market.

The technology developed was taken over and deployed by the co-financing partner, Maricultura Ltd. (Niță \& Nenciu, 2020a). The only mussel farm on the Romanian Black Sea coast was established in 1993 by Mirel Crivăț (Niță \& Nenciu, 2020a) and was operated by Maricultura Ltd. Starting with an initial investment of 400,000 euro, the Romanian farmer entered a partnership with Italian investors and developed a successful business. The technology used was the "longline" system, with mussel spat naturally collected from the environment (Niță \& Nenciu, 2020a). From 2009, Maricultura Ltd. produced and marketed more than 5 tonnes of mussels every year. In 2012, production peaked at 20 tonnes of mussels distributed mainly to restaurants along the Romanian coast. Unfortunately, in 
2016, the farm closed due to the absence of a microbiological classification of shellfish areas in Romania, and uncertainties regarding the water concession law. The microbiological classification was finally completed in 2020 by the Competent Authority following a survey by NIMRD conducted in relation to the creation of the Constanța GFCM Shellfish Aquaculture Demonstrative Center (S-ADC). With the microbiological classification in place, there is confidence that Maricultura Ltd. will resume its activity.

Sturgeons are highly valuable fish, both due to the quality of their meat and for caviar production. In view of their endangered status, aquaculture is the only option for these species (Zaharia et al., 2017). Experimental cultures of beluga (Huso huso Linnaeus, 1758) and Russian sturgeon (Acipenser gueldenstaedti Brandt \& Ratzeberg, 1833) in Black Sea water were performed at NIMRD in the period 2005-2007. These first experiments proved the capacity of beluga and Russian sturgeon to adapt to marine water, even from the age of six months (Zaharia et al., 2008). Growth performance of Russian sturgeon in fresh and marine water were compared in research trials performed in 2007 and 2008. The growth parameters of Russian sturgeon in marine water were assessed to be superior to those of the same species reared in freshwater (Zaharia et al., 2011).

More recently, in 2017 an experiment sought to establish the age and salinity thresholds for rearing Siberian sturgeon, Acipenser baerii (Brandt, 1869) in NIMRD's RAS using Black Sea water (Niță et al., 2018b). The results obtained suggested that while juvenile Siberian sturgeons (5-7 months old) presented some of the morphophysiological mechanisms needed to adapt to hyperosmotic environments, like it has been described in other sturgeon species, they cannot be deemed hyperosmotic regulators, as they were unable to maintain their plasma osmolality and electrolyte balance in salinities higher than 7\%o. Additional research in this regard will be pursued, expanding the adaptation experiment to adult $A$. baerii specimens. The objective of this research is to decrease the pressure on wild sturgeon stocks by introducing a new species to marine aquaculture.

National and international demand for Black Sea turbot (Scophthalmus maeoticus Pallas, 1814) make this species an important candidate for aquaculture production as in the past years, the stock has been dramatically depleted due to unregulated fishing. In 2012, it was considered relevant to examine if nonnative turbot species could be reared successfully in Black Sea waters (Niță et al., 2012). Preliminary results suggest that the North Sea turbot Scophtalmus maximus (Linnaeus, 1758) shows high adaptability to the local environment and good growth performances and is thus a potential candidate species for mariculture in the Black Sea. This suggests a high potential to meet turbot demand on the Romanian market (Niță et al., 2012). SeaQualia Elcomex was the first turbot farm in Romania.
Completed in 2013 with an investment of 5 million euro, SeaQualia was at that point the largest and most modern turbot rearing farm in southeast Europe. The farm operated a RAS and due to the advanced water filtration technologies, the daily water intake from the sea was only $10 \%$ of the entire amount. As SeaQualia could supply quantities of up to $2,500 \mathrm{~kg} /$ week of fresh turbot-including live fish-it was expected to be able to meet the entire annual demand for turbot on the Romanian market. The farm operated until 2014, when it was closed, and its license suspended.

In addition to performing research experiments on rearing highly valuable finfish species, such as sturgeons or turbot (Niță \& Nenciu, 2017), production of the golden-grey mullet (Chelon auratus Risso, 1810) was tested in a Recirculating Aquaculture System (RAS) (Niță et al., 2018a). Preliminary results obtained showed good adaptability and normal growth, which makes $C$. auratus a potential candidate for aquaculture. This species was tested in a RAS due to its availability, however, given the relatively low price of this fish, it is probably more feasible to further develop mullet culture in Romania in semi-intensive coastal pond systems, close to the sea. Other studies indicate that they can tolerate a wide range of temperatures and salinities, which makes them an appropriate species for extensive and semi-intensive aquaculture, in open (flow-through) systems (Niță \& Nenciu, 2020b).

Despite environmental and legislative constraints, the potential for developing marine aquaculture on the Romanian coast is significant. The microbiological classification will definitely give a boost to shellfish farming, while several economic operators have expressed interest in growing rainbow trout in seawater during the cold season. NIMRD is currently testing the growth rate and the optimal size for the introduction of rainbow trout juveniles in seawater. Moreover, integrating Black Sea fishing with freshwater aquaculture in a short supply chain would be a way for seafood restaurants along the coast to offer the full range of species available in the Danube and Black Sea basin at the highest quality and freshness. Finally, the research infrastructure, farmers' organisations, and international cooperation play a key role in developing and promoting innovative solutions to the challenges facing Romanian aquaculture.

\subsection{Aquaculture in the Russian Federation: Status and Modern Trends}

The Russian aquaculture sector has developed to produce fish, shellfish and crustaceans. This development has been greatly aided by the great diversity of the national environments, which include, among others, the Azov and Black Sea. Species are grown in a variety of aquaculture systems, including: freshwater ponds, tanks and channels, in brackish estuaries and lagoons, at sea in floating cages and bivalves are farmed in suspended "long-lines" (FAO, 
2005-2021). The aquaculture sector is regulated by the Federal Law "On aquaculture (fish farming) and on amendments to certain legislative acts of the Russian Federation" (Russian Federation, 2013).

Since the beginning of the 1950s, artificial reproduction of anadromous fish began to develop in the former Soviet Union. The original drive behind the development of aquaculture techniques was represented by the need to compensate for the negative effects of artificial dams and reservoirs construction on natural stocks abundance. The species mostly affected by the disruption of natural migratory routes were the Russian sturgeon (Acipenser gueldenstaedtii), beluga (Huso huso), starry sturgeon (Acipenser stellatus), Black Sea salmon (Salmo labrax). In addition, the development of rice agriculture had caused negative impacts on natural stocks of pike perch (Sander lucioperca), sea roach (Rutilus heckelii) and common bream (Abramis brama). In order to overcome these challenges, two types of fish farms were developed: nurseries and so-called spawning farms. Spawning farms are managed natural environments, normally lagoons, where fish are protected from predators and natural spawning can occur. Farms for artificial reproduction continued their restocking actions for decades mostly focusing on semi-anadromous species (e.g. pike perch, sea roach, bream). Hatcheries production have, instead, specialized in the production of sturgeons, salmonids and marine species including grey mullet (Chelon auratus), leaping mullet (Chelon saliens), flathead grey mullet (Mugil cephalus), so-iuy mullet (Planiliza haematocheilus) and Black Sea turbot (Scophthalmus maeoticus). Today, aquaculture for restocking is a powerful and sustainable sector. The release of juveniles of semi-anadromous fish in the Azov Sea exceeds 5 billion juveniles annually, followed by sturgeons and Black Sea salmon restocking. The release of juveniles of semi-anadromous fish of the Azov Sea (pike perch and sea roach) is leading in terms of quantity (5-6 billion juveniles annually). Second to this are anadromous sturgeon fish (9-12 million juveniles annually). The release of Black Sea salmon in recent years has not exceeded half a million juveniles (0.3-0.5 million annually).

Nonetheless, the sector needs to overcome pressing challenges for the future, including renovation of outdated facilities, conservation of genetic diversity of the species used for restocking and the organization for the breeding of declining marine species.

\subsubsection{Knowledge Transfer: from Restocking to Commercial Aquaculture Activities}

The technologies for breeding and nursery stages of various species, originally developed for restocking, were applied in the Union of Soviet Socialist Republics (USSR) for commercial aquaculture by the end of the 1960s.

After an initial phase of sturgeon species and their hybrids being the main focus of breeding activities, the striped bass (Morone saxatilis) was introduced and, since the 1970s, the breeding efforts have also included bivalves species. Along with the native species such as European flat oyster (Ostrea edulis) and mussels (Mytilus galloprovincialis), the research involved Pacific oyster (Crassostrea gigas) farming in the Black Sea. From 1984 to 1995, the "Research and Experimental Facility for Mariculture" was active in Krasnodar territory to enable the farming of sturgeons, salmons, European seabass, striped bass, turbot, mullets, mussels, oysters and live feeds. In the first years of the new century a decline in production started, due to a lack of State funding and support to farmers, ambiguous policies and a general trend of commercial aquaculture decline in the Black Sea. In 2013, with the adoption of the legal framework regulating aquaculture activities (Russian Federation, 2013), State support for farms has resumed allowing for new development. In 2020 the Russian aquaculture production has reached an overall volume of 291,200 tonnes (Russian Federation, 2021), of which about one quarter (70,100 tonnes) is produced within the Southern Federal District. This region borders the Black Sea and leads in terms of productivity although almost all volume is represented by freshwater species. Regarding the Azov and Black Sea aquaculture, the traditional extensive brackish water aquaculture in coastal lagoons is focused on native mullets (i.e. golden mullet, leaping mullet and grey mullet) and the so-iuy mullet, naturalized in the Black Sea. More recently, commercial aquaculture of mullets in the Russian part of the Black Sea is negligible, accounting for 50 tonnes of so-iuy mullet, attributed to the lack of farming activities in other water bodies. For successful development, new tools and activities are required including GIS mapping of lagoons, determination of biological parameters and the development and organisation of hatchery activities. The marine aquaculture sector has instead developed in the Azov and Black Sea, however, despite its history and scientific base, is currently a small sector and makes no significant contribution to the total volume of production. Shellfish aquaculture is considered the most dynamic sector of Russian aquaculture in the Black Sea. In the last 6 years, shellfish farms have increased their production from 200 to 1,900 tonnes, of which about 1,200 tonnes of $C$. gigas and about 690 tonnes of $M$. galloprovincialis (Russian Federation, 2020). Shellfish farms occupy more than 40 marine coastal areas up to 30 hectares each and are located near popular resorts. While the mussel production is based on the native seed, almost all the oyster seed is imported and a small part is collected in the Primorsky Territory. Recent findings have found that it is the natural reproduction of $C$. gigas in the Black Sea that is allowing for the progression of local shellfish production. The key barriers faced by the mussel and oyster farms in the Black Sea are divided into natural and anthropogenic factors. Natural factors include climate warming and natural disasters (i.e. storm, floods) while 
anthropogenic factors include water pollution, competition for space and deficiencies in the regulatory framework.

\subsubsection{Regulatory Framework and Spatial Planning}

The Federal Law "On aquaculture (fish farming) and on amendments to certain legislative acts of the Russian Federation" (Russian Federation, 2013) defines principles, methods, economic foundations and procedures for aquaculture development, it furthermore identifies the penalties for the violation of the legislation. Together with this Federal Law, the regulatory framework for aquaculture includes other Federal Laws which apply partially to the sector. The policy framework covers all aspects of aquaculture production and contributes to sustainable development but does however lack integration with environmental regulations and is hindered by slow procedures for its improvement, excessive bureaucracy at farm level and insufficient transparency in spatial planning and farm establishment. The steps forward to shape a better and more efficient governance need to include examples provided by worldwide experiences in spatial planning (e.g. AZA principles), a renewed cross-ministry interaction and the involvement of the stakeholders' associations. The need for spatial planning for sustainable development of aquaculture, especially in coastal marine areas, is becoming acutely recognized in the Russian Federation. Initially, there were no elements of spatial planning in the existing legal framework. More recently, however, it became clearer that the development of aquaculture could cause tensions in coastal regions. Pilot experiences in 2017 in Primorsky Territory laid the groundwork for spatial planning principles to be implemented, even though this is not yet fully implemented in Black Sea. New remote sensing methods and GIS-technologies to determine the suitability of farming areas, a common shared database to involve stakeholders and government and new means of participatory approach are the solutions identified following the AZA example, for the sound development of spatial planning and environmental protection in the Russian Federation. Future biological suitability assessment will also need to take climate change and the threats it poses into consideration.

Indeed, the regions of the Russian Federation bordering the Black Sea have faced large-scale climatic changes in recent decades leading to new challenges for the aquaculture industry. Increase in water temperatures, abnormal and unpredictable temperature peaks, natural disasters like storms and floods and the salinization of the Azov Sea are among the urgent matters to tackle. The shellfish sector can be particularly affected by climate change; high temperatures and rapid environmental changes can disrupt the delicate ecosystem dynamics that the farming of these species rely upon. These changes can include variation in phytoplankton availability, seed recruitment, growth and gonadal development. Furthermore, increased freshwater inputs and acidification poses unique osmotic and biomineralization challenges on these animals' physiology (Fitzer et al., 2014). In addition, the penetration of invasive thermophilic species and new pathogens will pose new threats for the finfish sector in the coming years. A strategy for aquaculture to effectively adapt to these pressures are required and should include the application to Mediterranean invasive fish species or plants, and a mitigation plan for autochthonous fish stocks depletion.

\subsubsection{Meeting Market Demand: Development and Improvement of Technologies and Research}

The Russian market demand related to seafood products requires a stable year-round supply to the Hotel, Restaurant and Catering (HoReCA) sector. The product in demand is highly related to the place of consumption, coastal touristic areas demand for fresh products while processed products are expected in megacities as Moscow and St. Petersburg. The Russian aquaculture is not able yet to meet these needs and the small volumes of productions lead to higher costs of production and a higher selling price. The urgent task of reducing the production costs requires scientific research and organization to allow for structural and biological improvements. The structural improvements identified include the development of hatchery technologies to reduce the dependence on the import and wild seed and the technical means have to adapt to the changing natural conditions to reduce manpower and face emergencies. The biological priorities include, among others, genetic research, early diagnostic solutions and vaccines to reduce mortality in early developmental stages.

In summary, we can identify the main factors in Russian aquaculture development within the Azov-Black sea region as: (i) the prevailing role of artificial reproduction in terms of the quantity of juveniles released for both restocking and farming and in terms of species diversity; (ii) dynamic development of industrial aquaculture of bivalve molluscs; (iii) improvements in the sector management, and (iv) the increased role of science that is required to overcome constraints.

\subsection{Aquaculture in Turkey: A Regional Focus on Sea Cages in the Black Sea}

\subsubsection{History and Modern Development of Aquaculture in Turkey.}

Turkish aquaculture has grown by almost $371 \%$ in the last twenty years (TUIK, 2020; BSGM, 2020). The first aquaculture activities in Turkey were located in Bilecik in 1969. Cage aquaculture started with European seabass (Dicentrarchus labrax) and gilthead seabream (Sparus aurata) in 1985 in the Aegean Sea and by 1986, 
Turkey reported an aquaculture production of 3,040 tonnes of trout and 35 tonnes of seabream and seabass (Çoban et al., 2020).

In the late $80 \mathrm{~s}$, the Turkish capture fisheries production from the Black Sea, which accounted for $85 \%$ of marine fish production, decreased due to factors such as overfishing and pollution., and hence this which in turn stimulated efforts towards the scoping of the Turkish Black Sea coastline for the development of farming in sea cages. The latter started in 1988-1989 with the production of Atlantic salmon (Salmo salar) and the rainbow trout (Onchorhyncus mykiss), though eventually the production of Atlantic salmon stopped due to the intolerance of this species to the high water temperature (Memis et al., 2002).

In 2019, the national aquaculture production reached 373,356 tonnes, of which marine production accounted for 256,930 tonnes (68.8\%) and 116,426 tonnes (31.2\%) from inland farming (Ministry of Agriculture and Forestry, 2020). The former includes 137,419 tonnes of seabass and 99,730 tonnes of seabream produced in both the Mediterranean and the Black Sea, and 9,692 tonnes of trout which are farmed in the Black Sea (Çoban et al., 2020; Ministry of Agriculture and Forestry, 2020). The market demand for trout farmed at sea has steadily grown over time and it is expected to result in an increased local production in the future.

\subsubsection{Farmed Species and Production Cycles Adaptations to Black Sea Conditions}

Rainbow trout is the main salmonid farmed in Turkey. Eggs are usually produced in January-February in freshwater hatcheries, then incubated at $13^{\circ} \mathrm{C}$ for about a month. It takes 12 to 18 months for the fry to reach market size (200-250 g) in freshwater facilities. Rainbow trout are then transported to sea cages in November-December, when the Black Sea surface water temperature drops below $17^{\circ} \mathrm{C}$, fish are then either harvested or moved back to freshwater facilities before the surface water temperature reaches the critical maximum temperature for rainbow trout at the end of June (Akbulut, 1998). The transfers between freshwater facilities to sea cages could continue until the desirable size is reached according to market demand, i.e. 200$250 \mathrm{~g}, 500-700 \mathrm{~g}, 1.0-2.5 \mathrm{~kg}$ and $3.5-4.5 \mathrm{~kg}$. The fish are then sold either whole or as fillets.

Black Sea trout (Salmo labrax) is an anadromous and endemic species of the Salmonidae family with high commercial value, distributed in the Eastern Black Sea region (Geldiay \& Balık, 1996; Innal \& Erk'akan, 2006). The research on this species for aquaculture started in 1982 (Okumuş et al., 2007), while in 1988 a study to assess the wild stock status of sea trout in the Eastern Black Sea was carried out in cooperation with FAO and preliminary studies of hatcheries site selection for production under controlled conditions were conducted (Edwards \& Doroshov, 1989).
Another benchmark investigation by the Fisheries Central Research Institute (SUMAE) in 2001, identified the most suitable broodstock characteristics and was followed by studies on morphology, breeding, feeding and migration characteristics of the Black Sea trout, as well as the potential for this species to be used in commercial aquaculture (Tabak et al., 2001). As of 2018, approximately 60 private enterprises were successfully farming the Black Sea trout with a production of 2,924 tonnes in inland water and marine systems (BSGM, 2020).

Salmonid farming along the Black Sea coasts of Turkey faces increasing issues when the summer temperatures reach $20^{\circ} \mathrm{C}$. As a consequence, many entrepreneurs have stopped this activity while others started looking for alternatives. Seabass has been considered as an alternative species to be farmed in the brackish waters of the Black Sea and the offspring and grow-out production of this species started in 1985 (Alpbaz, 1990; Uçal \& Benli, 1993). Akbulut \& Şahin (1999), in their study to determine the growth performance of seabass in sea cages under Black Sea conditions when the water temperature is above $16^{\circ} \mathrm{C}$, reported that a specific growth rate above 0.5 has been achieved. They concluded that despite water temperature remaining an important limiting factor for the cultivation of this species in the Eastern Black Sea conditions, with the appropriate practices it would be possible to grow this species on a commercial scale in sea cages.

\subsubsection{Institutional and Legal Framework, The Licensing Process for Aquaculture Establishment}

The Ministry of Agriculture and Forestry (MAF) is the main state organization responsible for aquaculture administration, regulation, protection, promotion, and for the provisioning of technical assistance. The Directorate General of Fisheries and Aquaculture (BSGM) in the Turkish Ministry of Agriculture and Forestry is responsible for governance on aquaculture production. All producers must acquire a license from the Ministry which maintains an office presence in 81 provinces. Applications for the farming of trout, carp, seabass and seabream for on growing and hatchery production, with a capacity up to two million juveniles per year can be submitted to the Provincial Directorates, whilst applications for larger operations of on growing and hatchery production of the same species with a capacity above two million juveniles per year as well as on growing of other species should be applied directly to directorate in Ankara (FAO, 2012-2021).

All aquaculture activities are based on the Fisheries Law No. 1380, enacted in 1971. Aquaculture Regulation was first issued on $29^{\text {th }}$ June 2004 and was amended in $2005,2007,2009$. These laws cover and set out rules for a broad range of issues such as: site selection, licenses procedures, farms monitoring and control, environmental impacts and protection, project 
approvals, farms improvements, imports of live fish and related materials, animal health management and welfare, and staff employment. The legislation also covers matters related to specific aquaculture techniques and practices such as tuna fattening and organic farming.

Authority over aquaculture is divided between the Turkish Ministry of Agriculture and Forestry (MAF) and other Ministries such as Health, Transportation, Tourism, Environment and Culture. MAF must have internal site selection strategies so that the location of aquaculture developments takes environmental data into account. Information to be provided include, among other things, data on sea floor type, hydrography, farm size, environmental carrying capacity, environmental impact assessment and separation distances from other aquaculture sites (Republic of Turkey, 2004). Licensing of sites and subsequent monitoring activities are the main MAF duty in aquaculture regulation and it monitors conditions at representative aquaculture sites, before, during and after implementation of a project. Data gathered during monitoring can then be used to review and, if necessary, alter the licensed production capacity in the future.

\subsubsection{Aquatic Science and Aquaculture Research and Institutions in Turkey}

In Turkey, there are several Universities and Institutes providing undergraduate and graduate education in fisheries including aquaculture subjects, marine science and technology, aquatic sciences along with fisheries programmes in vocational education at high school level. Among these, the Central Fisheries Research Institute (SUMAE) associated with the Ministry of Agriculture and Forestry is in Trabzon, a coastal Black Sea city. Another Fisheries Institute is established on the Mediterranean Coast in Antalya while two other institutes are in Egirdir/Isparta and in Elazig mostly focusing on inland freshwater aquaculture matters.

\subsubsection{Challenges in Ensuring Sustainable Development, An Outlook Over the Turkish Aquaculture Sector}

At present, the Turkish aquaculture sector is striving for development and it is challenged by numerous constraints which do not allow for effective, sustainable and widespread growth: diversification, social acceptability, misperceptions, conflict for space at sea, time consuming bureaucracy and lack of skilled manpower availability are the main bottlenecks identified. In the authors' collective experience, Black Sea aquaculture in Turkey has not been able to diversify its production for many years due to an insufficient market demand and some degree of price volatility. Insufficient internal market demand derives from a misconception surrounding aquaculture products when compared to wild catch fishery products. Conflicts between aquaculture and local communities still remain one of the main challenges (Soto et al., 2009) and misinformation about the negative impacts of farms is widely spread. Furthermore, conflicts may occur due to competition for space at sea for aquaculture site selection and lengthy, cumbersome administrative procedures to obtain aquaculture authorization hamper the sector growth. Challenges to be overcome also include the skilled manpower availability: cheap labour is highly available for low skilled positions but there is a consistent lack of experienced workers which directly influence the productivity of the sector and production costs. For the latter, SUMAE is continuously engaging and conducting educational training programmes.

\subsection{Ukrainian Aquaculture, A Long History: Present Status and Future Potential}

After a long history of extensive aquaculture in Ukraine, a national intensive development of the sector started in the middle of the last century peaking in 1988 when the total national production reached 96,182 tonnes including 78,026 tonnes of common carp, 322 tonnes of rainbow trout, 17,683 tonnes of silver carp, 146 tonnes of sturgeon, and 5 tonnes of flatfish (FAO, 2020c). This promising data has, however, constantly been dropping after the fragmentation of the Soviet Union in 1991, resulting in an overall production of 12,667 tonnes and estimated worth of US\$ 50 million in 2019 (Kukharev and Romanov, 1998; State Statistics Service of Ukraine, 2019). The Soviet Union has left a large heritage in the form of large aquaculture industrial and farming technological capacity across the nation. Farms are constituted of manmade earthen pond systems with water supplied by natural gravity and most of them still show significant potential for modern intensive aquaculture.

\subsubsection{Natural Aquatic Resources and The Development of a Diverse Aquaculture Sector}

Inland water resources cover $4 \%$ of the Ukrainian territory for an overall surface of $\mathbf{2 . 4}$ million ha. This very considerable area consists of both natural and artificial water bodies, including 49,000 aquaculture ponds. The ponds are classified into three categories: managed directly by the government, leased to the local executive authorities and local self-governed bodies and other that are not in use. More recent findings show only 7,850 waterbodies are employed for aquaculture purposes (FSA, 2015) and more than 100 of them are specialized in warm water pond fish farms. In 2016, the State Agency of Fisheries of Ukraine estimated that the potential pond production could be enhanced to produce 98,200 tonnes per year by applying modern technologies (FSA, 2015). Despite the presence of a significant number of freshwater sources, emerging droughts related to global warming are already becoming an issue for fish farmers (FSA, 2019; 
Adamenko, 2019; Shevchenko et al., 2019) and Ukrainian agro-climatic zones are currently undergoing drastic changes and significant ecological shifts (Adamenko, 2014 and 2019; Shevchenko, 2014). In 2017, the Ministry of agrarian policy and food of Ukraine has developed a draft document of "The State strategy on adaptation to climate change in agriculture, forestry and fisheries of Ukraine until 2030", where a lack of the effective measures to adapt to the climate changes was acknowledged (Minagro of Ukraine, 2017). In order to preserve the water bodies in use, importance has been given in the research for dangerous xenobiotics and their monitoring programmes (Sytnik, et al., 2008; Bondar, et al., 2020; Medinets, et al., 2017; Kras, et al., 2009; Myslyva, 2016; Yanovych, et al., 2016; Dobrjanska, et al., 2014), as well as pesticides and nitrogenphosphorus-containing fertilizers (Fodchenko, 2017; Bersan \& Sytnik, 2013; Barbukho, 2016) which frequently causes massive algal blooms in inland waters and at sea (Vyshnevskyi, 2019; Kirpenko, et al., 2020; Kirpenko, et al., 2019; Kovalenko \& Goncharuk, 2019).

Pond aquaculture is the single most common freshwater aquaculture system in Ukraine. The three main types of pond aquaculture are: specialized fish farms, unspecialized fish farms and culture-based fisheries farms (CBF). The first category includes 53,125 ha of fish farms, scattered homogenously across the country, that were the main production centres during USSR. These farms have middle and high levels of productivity up to $700 \mathrm{~kg}$ per hectares, specialized technologies and personnel and a strong market position with an all-year round trade. The dominant technology is semi-intensive carp and herbivorous fish pond polyculture. The most produced species are common carp (Cyprinous carpio), Chinese carps as bighead carp (Hypophthalmichthys nobilis), silver carp (Hypophthalmichthys molitrix) and grass carp (Ctenopharyngodon idella), crucian carp (Carassius carassius), pike (Esox lucius), pikeperch (Sander lucioperca), paddlefish (Polyodon spathula), European catfish (Silurus glanis), channel catfish (Ictalurus punctatus) and tench (Tinca tinca). Another 70,000 hectares of water reservoirs constitute the second group of "unspecialized fish farms", explicitly never used for aquaculture but rented by local farmers and private entrepreneurs. Fish productivity of these ponds is estimated to be up to $360 \mathrm{~kg}$ per hectare. The last group, consisting in "culture-based fisheries farms" (CBF), categorizes all the aquaculture farms run by the state to sustain the restocking activities of the exploited native fish stock as carps, pike, pikeperch and sterlet (Acipenser ruthenus). In the past, regular restocking activities were carried out and estimations show that nearly 210 tonnes more fish could be produced yearly thanks to these initiatives. In Ukraine, other forms of aquaculture are also in place: in 2019 for both the African Catfish and sturgeon, according to experts, the production exceeded 500 tonnes, while the yearly production of trout sector exceeded 1,500 tonnes by expert estimations. To produce these species intensive and more developed technologies such as Recirculation Aquaculture Systems (RAS) are in use.

\subsubsection{Vital Challenges for Sustainable Development: Policy for Marine Spatial Planning}

There is no scientific evaluation of the national marine areas as far as their suitability for marine aquaculture is concerned. Legislation does not provide real support for the establishment of marine farms or a mean to define allocated zones for aquaculture (AZA). Since the government included large coastal marine zones into marine protected areas, the establishment of marine aquaculture farms has become difficult within such zones. Therefore, the harmonization of MPAs (Marine Protected Areas) and the AZA establishment, crucial for marine aquaculture development, still is one of the modern national challenges faced by this developing sector and a critical aspect for the fulfilment of its potential. In addition, the current geopolitical situation further complicates the establishment of farms within open marine areas.

\subsubsection{Internal Market and Fish Consumption: A Promising Uptrend}

Fish consumption in Ukraine has sharply declined as a result of economic problems since 2014 when the strong currency devaluation and the reduced purchasing ability brought fish per capita consumption down to 7.3 $\mathrm{kg}$ per year. In the last years, an upward trend has been observed for fish consumption and there is evidence of recent economic recovery. In 2018, the fish consumption in Ukraine rose to $10.4 \mathrm{~kg}$ per capita (FAO, 2020c). It is however noteworthy that this indicator in Ukraine is always subject to seasonal fluctuations.

\subsubsection{Enhancing Productions, Diversification and Market-Oriented Aquaculture: The Future for Aquaculture Growth in Ukraine}

The potential for aquaculture in Ukrainian and the numerous routes in which this potential can be achieved are high, considering the many different types of aquaculture and CBF activities occuring. Only considering the estimations, aquaculture could reach 200,000 tonnes of low-cost annual production (FAO, $2019 \mathrm{~b})$. Trout production in mountainous regions could be a realistic alternative to imports and there is evidence supporting the concept that national trout and sturgeon feed production may be feasible. The potential for different sturgeon species to be produced in cages and RAS, or new activities such as the pond farming of starry sturgeons or ranching of native species are therefore promising. There are also promising possibilities for enhancing the diversification of the fish food products: the share of additional valuable fish could be increased in pond polyculture addressing as the aforementioned 
species like pike, pike-perch, European catfish, paddlefish and in the south so-iuy mullet. The creation of processed products would be a feasible way to add value to the present productions. A possible way of doing this might could be following some of the basic tendencies in pond fish culture as increasing the size of marketed fish. The production of processed products such as smoked or canned seafood has also space for improvement in the nation and can add value to the locally produced seafood.

\subsubsection{Future Perspectives: A Great Potential for Aquaculture Development}

In line with ongoing reforms and economy transition related to the Association Agreement with the EU (EU Legislation 161, 2014), Ukrainian aquaculture has a chance to thrive after a long stagnation period, to produce local market and export-oriented value-added fish products. A large consumer market, constant growing demand for fish, abundance of natural resources, low wages and proximity to the European Union market are some main competitive advantages of Ukraine. However, governmental attempts to rejuvenate the national aquaculture industry has been of no success in Ukraine and aquaculture production is not increasing. The lack of a comprehensive development strategy as well as the absence of a suitable indicator for steering Ukrainian aquaculture governance decision could be considered as the major obstacles for development (Buhlak et al, 2021). Indeed, the only indicators used to drive governmental policy are production statistics and public demand, highlighting the need for all government's decisions to have a clearer strategic vision. There is no doubt that aquaculture can provide considerable input to the economy, nutritional wellbeing for the nation and ensure food security to the country. Farmed Ukrainian fish is a valuable alternative to the imported fish and aquaculture will help to release anthropogenic pressures on overfished native stocks. Ukraine has a great potential for aquaculture development in inland waters, considering actual geographical and hydrological conditions. Coordinated actions by all aquaculture stakeholders and assistance from the government are needed to fulfil aquaculture potential.

\section{Boosting Aquaculture in The Black Sea: Conservation and Restocking; Species Diversification; Education and National Building Capacity, Research and Development, Risks}

\subsection{Aquaculture for Restocking and Stock Enhancement}

Aquaculture applied to fish restocking and stock enhancement involves the release of hatchery-reared juveniles to restore fish spawning biomass and to overcome recruitment limitations, thus acting as a capture fisheries management tool (Molony et al., 2005). The rationale for restocking and enhancement actions is that, according to specific conditions, technological interventions could substantially increase the exploitation of natural aquatic productivity, for example in circumstances where natural productivity is high but recruitment is limited, or to support recovery of endangered species (FAO, 2019a).

Restocking and stock enhancement activities should follow a responsible and precautionary approach in light of their potential impacts on the environment, on wild stocks and capture fisheries, and on biodiversity. Such activities should be coupled with a monitoring programme to assess its impacts. In this regard, the Convention on Biological Diversity (CBD) is a milestone in the international endeavour for the conservation of biodiversity as its parties are bound to, as far as possible and as appropriate, "ensure that activities within their jurisdiction or control do not cause damage to the environment of other States or of areas beyond the limits of national jurisdiction" (Article 3). In addition, the FAO Advisory Working Group on Aquatic Genetic Resources and Technologies has developed a comprehensive framework of minimum requirements to preserve and better manage existing aquatic diversity to enhance its contribution to food security, nutrition and livelihoods (FAO, 2016; FAO, 2018d). The Black Sea has witnessed several events of restocking and stock enhancement undertaken by the bordering countries. In the Russia Federation restoking is one of the main strategies followed by the country to boost fisheries production (see part 2.4). Additionally, Romania and Turkey also represent success stories in the region.

Romania has been at the forefront of sturgeon restocking, and two main programmes were implemented respectively between 2005 to 2009 and 2013 to 2015 . The programmes aimed at restoring the populations of wild sturgeon living and spawning in the Lower Danube River, along with other conservation measures including a sturgeon fishing ban since 2006 (Holoștenco et al., 2019). The first programme managed by the National Agency for Fishery and Aquaculture (NAFA) targeted the Romanian Lower Danube and included three anadromous sturgeon species still naturally spawning in the river: 1) Beluga (Huso huso), 2) Russian sturgeon (Acipenser gueldenstaedtii), and 3) starry sturgeon (Acipenser stellatus). To a lesser extent, these measures also targeted other freshwater resident species like the sterlet (Acipenser ruthenus) (Holoștenco et al., 2019). The programme followed a thorough protocol which was collectively decided by the Ministry of Agriculture, Forests and Rural Development and the Ministry of Environment and Water Management. Among other things, the protocol included the use of local broodstock captured in the Lower Danube and subsequently tagged with Passive Integrated Transponder (PIT) tags, the use of artificial reproduction methods which ensured the survival of breeders, and a specific fertilization scheme to maximize the genetic 
diversity (Holoștenco et al., 2019). The programme produced a total of 425,698 sturgeon juveniles. The juveniles were then tagged with coded wire tag (CWT) upon reaching a total length of about $10 \mathrm{~cm}$ to ensure good post release survival (Holoștenco et al., 2019). Regrettably, the efficiency of the restocking programme could not be evaluated during its lifetime or after the completion due to lack of financial support (Holoștenco et al., 2019). Furthermore, despite the protocol followed to ensure genetic diversity, this programme commenced without any previous genetic knowledge of the sturgeon populations still populating the Lower Danube. Only in the following years there have been progress in investigate the genetics of breeders caught in the Lower Danube in order to improve the protocol of restocking programmes. For example, in 2013 and 2014 four haplotypes for beluga sturgeon were identified based on mtDNA control region investigations (Onără et al., 2014) as well as ten haplotypes for starry sturgeon (Holoștenco et al., 2013) populations living in the Lower Danube.

The second sturgeon restocking programme in Romania was implemented by the Research and Development Center for Sturgeons, Aquatic Habitats and Biodiversity, within the "Lower Danube" University of Galaţi (Cristea et al., 2016). The sturgeon juveniles used were purchased by controlled breeding, from wild spawners caught in the Danube at the Tămădăul Mare / Călărași County and Horia / Tulcea County hatcheries in compliance with the national and European legislation in force. Before being released, juveniles were tagged with "Coded Wire Tag" (CWT).

A total of 200,000 sturgeon juveniles (aged 3 years in 2013 and aged 1 year in 2015) were released in the Danube, specifically 70,000 beluga sturgeons, 105,000 Russian sturgeons and 25,000 starry sturgeons (Cristea et al., 2016). Experts from bordering countries collected samples from sturgeons accidentally caught in the coastal areas of their country specifically at the mouth of the Sf. Gheorghe Branch in Romania, Ukraine, Georgia and at the mouth of the Sakarya River in Turkey (Cristea et al., 2016). Out of 1,627 sturgeon juveniles caught during the project implementation, 756 individuals $(46.6 \%)$ had the CWT tag being specimens experimentally released in the Danube in 2013 and 2015, respectively (Cristea et al., 2016).

Most sturgeon juveniles reaching the sea remained in front of the Danube mouths for feeding, whilst $1 \%$ of tagged individuals were driven by marine currents to the southern coasts of the Black Sea and were re-captured in front of the Sakarya river in Turkey. In addition, approximately $5 \%$ of the tagged individuals reached the Gulf of Odessa and close to the Crimean coast, driven by the northern gyre of the Rim current. In both cases specimens had smaller mean weight as compared to individuals caught in the Sfântu Gheorghe area, coming from the same restocking batch.

In Turkey, examples of restocking and stock enhancement programmes in the Black Sea include several species of sturgeons, Black Sea trout (Salmo labrax), and turbot (Scophthalmus maximus).

There are three species of sturgeon distributed in Turkish seas: starry sturgeon (Acipenser stellatus), Russian sturgeon (Acipenser gueldenstaedti), and beluga (H. huso), (Çiftci et al., 2013). Studies and projects on sturgeons commenced in the 1970s when important measures to protect them were put in place, including the fishery and environment protection (Akbulut et al., 2011). Significant experiences related to sturgeon culture have been gained through a project started in 2001 and led by the Central Fisheries Research Institute (SUMAE), such as rearing techniques (Akbulut et al., 2009b; Özdemir and Akbulut, 2007), seed production (Aydın et al., 2012a, 2012b; Akbulut and Aydın, 2012) growth performance (Akbulut et al., 2013), tagging and monitoring procedures (Ustaoğlu et al., 2011), conservation (Akbulut et al., 2011; Memiş et al., 2008), and disease (Ture et al., 2018).

An important role has also been played by the Turkish Agricultural Research and Policy General Directorate (TAGEM) in funding projects aimed at supporting the recovery of sturgeons' natural stocks. Within a project carried out from 2008 to 2011, 5,500 Russian sturgeons were bred in Amasya-Yedikır production facilities and were released in the Yeşilırmak, Kızılırmak, and Sakarya rivers for restocking purposes. In this context, since 2011, the Central Fisheries Research Institute (SUMAE) has developed a mass production technique for sturgeon restocking by establishing sturgeon breeding stocks, developing breeding techniques, and protecting natural stocks. In recent years, 5,000 sturgeons are annually released to the sea by SUMAE as a part of the Ministry of Agriculture and Forestry's national fisheries programme.

The Black Sea trout (Salmo labrax) is an important species in Turkey and is preferred in aquaculture and restocking activities due to its high economic value, as in European countries (Elliott, 1994; Çakmak et al., 2007). This species has been widely cultivated for the past forty years due to successful restocking (Çakmak et al., 2007). Black Sea trout culture was started in 1998 by SUMAE within a project funded by TAGEM which concluded that economic production could be made after a few generations, by applying scientific selection methods (Tabak et al., 2002). Since then, several projects have also focused on the breeding, farming and use of the Black Sea trout for restocking purposes (Çakmak et al., 2007). Within the restocking project "Black Sea trout breeding and use for restocking purposes" implemented by SUMAE, a total of 2,624 tagged Black Sea trout were released into the sea in four different locations. Released fish were monitored at certain time intervals, and the average re-capture rate from the stations was estimated at $6.7 \%$. Restocking and stock enhancement of Turbot are also carried out in Turkey (Zengin et al., 2005; Aydın et al., 2011a; Aydın et al., 2011b; Beken et al., 2014; Ak et al., 2016; Aydın et al., 2020). 
Interest in the restocking of turbot originated from the public and private sector in line with increased awareness of the depletion of natural resources and a need for conservation of this species in Turkey. During a period of four years between 1999 and 2002, a total of 28,876 turbot hatchery-reared juveniles with a mean length of $13.9 \mathrm{~cm}$ were released at eleven different locations in the south-eastern Black Sea (Zengin et al., 2005; Zengin \& Gümüş, 2013). Recapture has been carried out on an average of $60 \mathrm{~km}$ of coastline from the released place by using bottom trawls, gill nets and purse seines nets, with a capture rate of $2.2 \%$ (Zengin et al., 2005; Zengin \& Gümüş, 2013). Furthermore, it was found that the animals migrated both vertically and horizontally depending on age, size and season (Zengin et al., 2005; Zengin \& Gümüş, 2013).

Currently, each year, about 10,000 turbots are released into the sea. The activities often involve children and the general public with the aim of increasing environmental awareness, while relevant stakeholders, especially fishers, support the programme.

\subsection{Species Diversification in The Black Sea Mariculture}

Aquaculture is the world's fastest growing food production sector, it is also one of the most varied in terms of farming practice, farmed species, and environments used (Harvey et al., 2017).

According to FAO statistics (FAO, 2020c), in 2018 about 445 species were farmed, of which about 345 are finfish and more that 100 are invertebrates. These are farmed in all aquatic environments including freshwater, brackish and marine waters. However, several countries still require guidance to develop sustainable strategies to increase production and to further diversify the sector. This is also the case of Mediterranean and Black Sea countries where the growing consumer demand, the status of overexploitation of fisheries stocks and the whole negative trade balance in relation to the import/export of the fishery food products (Massa et al., 2017) has called for the need of diversification of aquaculture in terms of species and market, which is considered to be essential for the future development and viability of the industry (Barazi-Yeroulanos, 2010). The issue of diversification of species in aquaculture is important and is permanently on the research agenda (Ojeda, 2015) as such it has been considered within the Strategy for the sustainable development of Mediterranean and Black Sea aquaculture (FAO, 2018c).

Considering that species diversification is a priority, farming native species could also represent an advantage in terms of conservation of biodiversity, for example by reducing the environmental risk in case of escapee events from fish farming, or by using aquaculture for restocking of vulnerable species (Le Gouvello et al., 2017). Furthermore, it promotes local economy integration by giving additional opportunities in terms of activities to the local communities (Chia et al., 2009; Fontaine et al., 2009; Scorvo-Filho et al., 2010).

There are two strategies to increase species diversity in aquaculture for meat production or stock enhancement. One of them is the cultivation of local species while the other is to use farmed species produced elsewhere. Domestication is enabling the reproduction, maintenance and growth of organisms in a human-provided environment or conditions (Ruzzante, 1994; Liao and Huang, 2000) and involves genetic changes over generations (Lorenzen et al., 2012). According to Teletchea and Fontaine (2012) the objective of the domestication is to, via selective breeding, promote animals with behavioural or physiological traits far from their wild ancestors and be more aligned with human usages.

Criteria such as biological, economic, ecological and quantitative indices for the selection of candidate species for aquaculture remain important. Desk studies using such indices can be useful pointers to culture potential and to prioritizing species for farming trials. For example, Tucker et al., (2017) proposed a unifying framework to approach diverse phylo-diversity metrics and understand biological diversity and thus be a helpful tool when selecting new candidate species. Furthermore, Mathews and Samuel (1992) suggested a simple bioeconomic culture index $(\mathrm{Cl})$ for ranking new candidate species for aquaculture that takes into consideration biological characteristics of these new candidate species (e.g. growth rate) as well as their market value, and applications of this tool may be applied to the Black Sea and other regions.

Marine aquaculture development in Black Sea is characterised by a limited number of species and, among other important factors, diversification could help to support aquaculture expansion in the region. In this regard, in 2013 an ad-hoc meeting on Black Sea aquaculture species diversification was held at the Central Fisheries Research Institute (CFRI) organised by the GFCM, and attended among others by experts from Bulgaria, Romania, the Russian Federation, Turkey and Ukraine. Experts identified a list of potential species for aquaculture to be used for human consumption, restocking, and for commercial and pilot commercial farms. These are reported in Table 6 and included trout (Salmo labrax and Oncorhynchus mykiss), turbot (Scophthalmus maximus), European flounder (Platichthys flesus), several sturgeon species, meagre (Argyrosomus regius), shi drum (Umbrina cirrosa), Sharpsnout seabream (Diplodus puntazzo), white seabream (Diplodus sargus), mullets (Mugil cephalus and Liza aurata), tub gurnard (Chelidonichthys lucerna), horse mackerel (Trachurus trachurus and Trachurus mediterraneus), Mediterranean mussel (Mytilus galloprovincialis), and oysters (Crassostrea gigas and Ostrea edulis). 
Table 6. List of potential species suitable for aquaculture in the Black Sea Region

\begin{tabular}{|c|c|c|c|c|c|c|c|c|c|c|c|c|}
\hline \multirow[b]{2}{*}{ 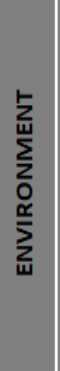 } & \multirow[b]{2}{*}{$\begin{array}{l}0 \\
0 \\
0 \\
0 \\
0 \\
0\end{array}$} & \multirow[b]{2}{*}{ SPECIES } & \multirow[b]{2}{*}{ 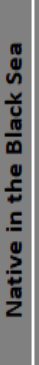 } & \multirow[b]{2}{*}{$\begin{array}{l}\text { Type of aquaculture system } \\
\text { tested or developed }\end{array}$} & \multicolumn{2}{|c|}{$\begin{array}{l}\text { Aquaculture } \\
\text { purposes }\end{array}$} & \multicolumn{3}{|c|}{$\begin{array}{c}\text { Aquaculture in the } \\
\text { Black Sea }\end{array}$} & \multicolumn{3}{|c|}{$\begin{array}{l}\text { Range of tolerance } \\
\text { conditions }\end{array}$} \\
\hline & & & & & 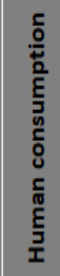 & 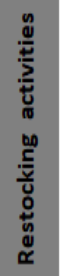 & 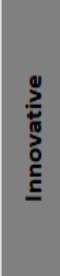 & 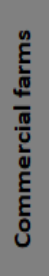 & 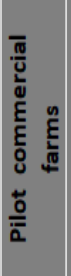 & 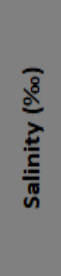 & 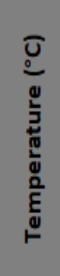 & \\
\hline \multirow{13}{*}{ 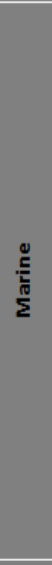 } & \multirow{11}{*}{ Fish } & Turbot (Schophthalmus maximus) & Y & Pond and tank culture & y & y & y & y & y & 5-38 & $5-25$ & $>5$ \\
\hline & & European seabass (Dicentrarchus labrax) & y & Sea cage / Pond and tank culture & y & N & - & y & - & $5-50$ & $2-32$ & $>5$ \\
\hline & & European flounder (Platichtys flesus) & Y & Pond and tank culture & y & N & y & - & y & $0-38$ & $5-25$ & $>4$ \\
\hline & & Horse mackerel (Trachurus trachurus, Trachurus mediterraneus) & y & Research phase & - & N & y & N & - & - & - & - \\
\hline & & Meagre (Argyrosomus regius) & y & Sea cage & y & $N$ & y & y & y & $5-38$ & $5-25$ & $>5$ \\
\hline & & Shi Drum (Umbrina cirrosa) & y & Pond and tank culture & y & $N$ & y & - & $y$ & $5-38$ & $5-25$ & $>5$ \\
\hline & & Brown meagre (Sciaena umbra) & Y & Pond and tank culture & y & $N$ & y & - & y & $5-38$ & $5-25$ & $>5$ \\
\hline & & Sharpsnout seabream (Diplodus puntazzo) & y & Sea cage / Pond and tank culture & y & $N$ & y & - & y & $5-40$ & $5-25$ & $>5$ \\
\hline & & White seabream (Diplodus sargus) & y & Sea cage / Pond and tank culture & y & $N$ & Y & - & y & $5-40$ & $5-25$ & $>5$ \\
\hline & & Mullets (Mugilc cephalus, Liza aurata) & y & Sea cage / Pond and tank culture & y & $N$ & y & - & - & $0-60$ & 3-35 & $>4$ \\
\hline & & Tub gurnard (Chelidonichthys lucerna) & & Research phase & y & $y$ & y & $N$ & $N$ & $5-38$ & $5-25$ & $>5$ \\
\hline & \multirow{2}{*}{ Mollusc } & Mediterranean mussel (Mytilus galloprovincialis) & y & Long-line and rafts in the sea & y & $N$ & - & y & - & $4-38$ & $5-28$ & $>5$ \\
\hline & & Oysters (Crassostrea gigas, Ostrea edulis) & $N$ & Long-line and rafts in the sea & y & N & - & y & - & $18-30$ & $15-22$ & $>6$ \\
\hline \multirow{6}{*}{ 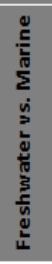 } & \multirow{6}{*}{ Fish } & \pm Black Sea trout (Salmo labrax) & r & Sea / Freshwater ponds and cages & y & r & y & y & r & $0-30$ & $4-20$ & $>6$ \\
\hline & & Rainbow trout (Oncorhynchus mykiss) & $N$ & Sea / Freshwater ponds and cages & y & r & y & y & y & $0-30$ & 4-24 & $>5$ \\
\hline & & \multirow{2}{*}{$\begin{array}{ll}\text { Beluga (Huso huso) } \\
\text { ¿ } \\
\text { Russian sturgeon (Acipenser gueldenstaedtii) }\end{array}$} & y & Marine and Freshwater ponds/tanks & y & r & y & y & r & $0-30$ & $2-22$ & $>5$ \\
\hline & & & y & Marine and Freshwater ponds/tanks & y & y & y & y & y & $0-30$ & $2-22$ & $>5$ \\
\hline & & \multirow{2}{*}{$\begin{array}{l}\text { Starry sturgeon (Acipenser stellatus) } \\
\text { Siberian sturgeon (Acipenser baerii) }\end{array}$} & r & Marine and Freshwater ponds/tanks & y & Y & y & y & y & $0-30$ & $2-22$ & $>5$ \\
\hline & & & $N$ & Marine and Freshwater ponds/tanks & $N$ & $N$ & $N$ & y & y & $0-10$ & $0-25$ & $>5$ \\
\hline
\end{tabular}

\subsection{The Aquaculture Demonstrative Centres: $A$ Tailored Service for the Black Sea}

Aquaculture Demonstrative Centres (ADCs) were established as the follow up of the GFCM High-level conference towards enhanced cooperation on Black Sea Fisheries and Aquaculture (Bucharest, Romania, 24-25 October 2016). The first benchmark was the meeting that was held in Constanta in September 2017 and hosted by the National Institute for Marine Research and Development (NIMRD) "Grigore Antipa". This event on the establishment of an Aquaculture Demonstrative Centre to promote sustainable aquaculture in the Black Sea, decided upon the main aims, objectives and terms of references of the ADC. The GFCM Commission at its forty-first session (Montenegro, 2017) acknowledged and welcomed the initiative to establish the ADC. The focus technical meeting was thus considered as the start-up of the ADC initiatives. At the high-level conference on Black Sea Fisheries and Aquaculture (Sofia, Bulgaria, 6-7 June 2018), declarations have been made to enhance the regional cooperation in the sector, marked by a strong political commitment to increase collaboration with a view of promoting the: i) rational exploitation of marine living resources; ii) sustainable development of aquaculture; iii) mitigation of threats facing the marine environment and vulnerable species (FAO, 2018b).

The nature and functions of the ADCs were stated at the Working Group on the Black Sea (WGBS) (Constanta, Romania, 13-16 June 2018). ADCs could be considered as the regional hubs capable to timely react to Black Sea countries' expectations and needs in order to develop the aquaculture sector and a useful tool for local and national authorities to evaluate new aquaculture projects proposals. In consideration of the different level of national aquaculture development, environment and requirements, $A D C$ s could also attract the interest of the private sector to invest on aquaculture projects which would ultimately result in further jobs creation opportunities.

ADCs units were established in Romania and Turkey, at the National Institute for Marine Research and Development (NIMRD) "Grigore Antipa" in Constanta, and at the Central Fisheries Research Institute (SUMAE) in Trabzon.

The ADC is considering species and farming technologies for both demonstration and technology transfer, especially for outdoor and offshore installations. ADC targets to bring benefit to national and local management authorities involved in aquaculture planning, management and sanitary 
control, small-scale producers with limited investment capacity, private investors, public institutions and other organizations (e.g. NGOs), with the aim of increasing their awareness on the relevance of aquaculture potential for national economies. Furthermore, existing scientific networks (e.g. Black Sea University Network) that could benefit from aquaculture capacity development training courses, national and international aquaculture research institutes and organizations, current and future alliances between fisheries actors and other local private and public stakeholders (e.g. FLAGs - Fisheries Local Action Groups) are too considered to be significant stakeholders in this endeavour.

In order to progress with the launch of the ADC activities, a set of training programmes were developed and some of them have been already completed with the participation of trainees from Bulgaria, Georgia, Romania, Russian Federation, Turkey and Ukraine. Topics covered included: a demonstrative training on Black Sea turbot farming and restocking (May 2018, Trabzon, Turkey), training on mussel farming (September, 2018, Constanta, Romania), shellfish pathologies (6-10 May 2019, Constanta, Romania), and training on trout farming in RAS (16-21 July 2019, Trabzon, Turkey).

$A D C$ activities have continued to deliver high quality training despite Covid-19 pandemic, via an online platform. Topics covered include: shellfish environment and pathologies (13-16 April 2020, Online), turbot aquaculture and restocking (20-24 April 2020, Online), Recirculating Aquaculture Systems (27 April - 1 May 2020, Online), and demonstrative training on finfish pathology (March 2021) by SUMAE, with the participation of more than 4,000 trainees.

\subsubsection{The Road Ahead}

The ADC activities are based on end-users' needs and the training modules showcase different aquaculture production technologies (e.g., intensive, semi-intensive) and productive systems (e.g.: cages, tanks, RAS and longline for shellfish) applicable to the Black Sea coastal areas. The modules are considering well-established systems, species and technologies that have proven to reduce investment risks, and that can be made available upon users' request, providing hands-on practical experience and facilitating technology transfer. The ADC is also addressing the topics related to the use of aquaculture for restocking purposes and ensuring that proper protocols and guidelines are strictly followed.

In support of the ADC activities, demonstrative/didactic material is being produced such as leaflets, guidance documents and videos to share success stories, good practices, experience, and technical knowledge generated by the many aquaculture projects and initiatives implemented in the Black Sea area. This material is being translated into riparian countries languages for wide dissemination and to ensure maximum impact on local communities.

\subsection{R\&D Outcomes in The Black Sea and Their Potential Use in Supporting the Development of Regional Aquaculture}

\subsubsection{Aquaculture in The Black Sea: Future Focus}

Aquaculture is increasingly contributing to food security of growing global population; it is therefore necessary to sustainably exploit available resources applying knowledge-based policies supported by sound scientific research (Lounas et al., 2020). The importance of research and development programmes on aquaculture is widely recognised as an engine of sustainable aquaculture development (FAO, 2014). Research activities in the Black Sea countries are well developed, as evidenced by the number of institutions focused on aquaculture research. Going forward, aquaculture potential will be unlocked through the development, implementation and dissemination of technologies and farming protocols needed by the local industry. In this respect, the implementation of innovative technologies, including smart farming could facilitate a more sustainable development of the sector and a reduced environmental impact.

Environmental sustainability of aquaculture is a complex and multi-scale issue involving both direct and indirect interactions with the environment (Edwards, 2015). It is possible to sustain the present production rate in accordance with the carrying capacity of the aquatic environment, or even to increase production with limited environmental effects via implementation of modern technologies and careful management of the environmental impacts (Can et al., 2010).

The evolution of current practices in the Black Sea towards a more sustainable aquaculture industry could take advantages of practices and concepts from other regions of the world, which promise to improve its sustainability and environmental compatibility in delicate coastal areas. Examples of such practices are represented by Integrated multi-trophic aquaculture (IMTA), recirculation aquaculture system (RAS), and offshore aquaculture installations.

\subsubsection{Integrated Multi-Trophic Aquaculture (IMTA)}

Environmental sustainability of aquaculture is a complex issue involving effects at local, regional and global scales as a consequence of aquaculture treatments production (benthic deterioration, eutrophication, reduction fishery for fishmeal and fish oil production and emissions from production wastes) and industrial processes involved in the products' value chain (Chopin et al., 2012; Edwards, 2015; Chary et al., 2020). Integrated multi-trophic aquaculture (IMTA) is a concept in which the organic by-products (wastes) from the farming of a higher trophic species are recycled to 
become inputs (fertilizers, and food) for a lower trophic species. Within this promising concept, fed aquaculture species (e.g. finfish/shrimps) are farmed in combination with extractive species such as suspension feeders, deposit feeders, and seaweeds (FAO, 2009). Experimental models including mass-balance models (Troell and Norberg, 1998; Neori et al., 2004; Reid et al., 2013), field trials (Troell et al., 1997; Broch et al., 2013; Fossberg et al., 2018; Baltadakis et al., 2020) and economic models (Carras et al., 2019) have indicated that IMTA may have the potential to improve profitability and reduce the environmental impact of finfish aquaculture. Also highlighting, however, the numerous biological, practical and financial limitations linked with the implementation of the IMTA concept, particularly within the western world context. Indeed, although IMTA is a common practice in the East, few systems in Europe and America have been developed to full commercial scale for all species involved. Therefore, key questions linked to its efficiency in reducing impacts, its profitability and feasibility at commercial scale, still require rigorous empirical validation.

Even if there are no proof of implementation on commercial scale of IMTA activities in the Black Sea, along the Black Sea coast Turkey has been including the concept in aquaculture trials publishing a paper and a conference abstract in the last decade (Caruso, 2018).

Most fish and shellfish species cultured in the Black Sea region have potential to be integrated within an IMTA framework. Similarly, to most other geographic regions, however, the most suitable species, the integration of farming system to ensure trophic connectivity between trophic levels, the definition of appropriate sites suitable for all species farmed within the system, should be investigated at relevant scales before firm conclusions on the benefits of IMTA application can be drawn. Emerging species amongst deposit feeders, such as sea cucumbers and other echinoderms, could also play a role in the development of IMTA systems in the Black Sea region. Therefore, their ability to mitigate environmental impacts, the system design for their profitable farming, reliable and costeffective seed supply systems, as well as their place in the global market, should be thoroughly investigated at local and regional scale.

In addition to these species already subject of global research efforts (Zamora et al., 2016; Grosso et al., 2021), specific local species could also contribute to the implementation of IMTA in the Black Sea Region. For instance, tunicates such as Chondrosia reniformis are under investigation to explore their potential to be farmed in IMTA systems near the Bodrum Peninsula, Southwest Turkey (Gokalp et al., 2020).

\subsubsection{Recirculation Aquaculture System (RAS)}

The recirculation aquaculture system (RAS) is a technique that can be described as able to reuse water during the production cycle of fish and other aquatic organisms. The basic principle of the RAS is the treatment of effluent culture water through a series of consecutive processes including:

(1) filtration, including mechanical and physical filtration (using protein skimmers for fine organic particulate removal and activated carbon filters for toxic substances removal) (Murray et al., 2014) and nitrifying biofilters to oxidize ammonia excreted by fish (Espinal and Matulić, 2019); (2) disinfection including ozonation and UV filtration (Attramadal et al., 2012; Powell and Scolding, 2016; Huyben et al., 2018); and (3) oxygenation of the water before reinjection into the rearing tanks. Because of the high degree of water reutilisation, this type of systems are more independent from environmental and geographical characteristics than more traditional farming methods, they generally provide a more bio-secure farming environment where environmental contaminants can be excluded from the water intake. Furthermore, these systems can be adapted to the farming of different species (Tal et al., 2009).

Nonetheless, RAS also present some disadvantages, including: 1 . The system is dependent upon a regular power supply to secure continuous operation and good environmental conditions, 2 . The system requires special skills and knowhow and needs highly qualified work force, 3 . The system installation is relatively expensive, 4. Finally, operation of these systems also often involves higher energy consumption compared to more traditional open water farming methods. Despite the numerous advantages of RAS technology its operational cost (Suantika et al., 2003), has made this system less enticing for application at the farm level in the Black Sea region.

Nonetheless, egg incubation, pre-feeding and growth studies on Black Sea trout, rainbow trout, Siberian sturgeon and Turbot have been carried out in RAS units (Can et al., 2012; Çakmak et al., 2018; Ak et al., 2019; Türker et al., 2009; Polat et al, 2018). Future trials should also involve other relevant species farmed in the Black Sea such as sea-raised trout and European seabass and, potentially, explore integration between RAS farmed finfish and filter feeding and deposit feeding invertebrates.

\subsubsection{Offshore Aquaculture Installations}

The predicted future development and intensification of coastal and marine aquaculture is closely associated with a wide range of environmental issues that raise concerns about its long-term sustainability (Karakassis, 2013; Price et al., 2015; Massa et al., 2017). Offshore aquaculture, also known as open ocean aquaculture, is an approach to mariculture in which fish farms are located at some distance from the coast. The farms are positioned in deeper and less sheltered waters, with stronger ocean currents (Naylor and Burke, 2005). 
There is considerable interest in offshore aquaculture in response to the lack of suitable, sheltered coastal areas and the possible advantages offered by more exposed areas, such as increased water quality and oxygen supply, which increase production efficiency and fish quality. In addition, competing interests and conflicts of use, typical of near shore coastal areas, are limiting the development of new aquaculture sites, whilst offshore farming technology may provide an answer to these constraints. Indeed, multi-purpose use of offshore waters could lead to more responsible practiced aquaculture "in areas that can be simultaneously used for other activities such as energy production" (Lado-Insua et al., 2009). Examples of this type of cooperation between different users of the offshore environment is represented, for instance, by finfish and shellfish farming operations being co-located with oil extraction platforms $10 \mathrm{Km}$ off the shore of California (Devine, 2005) and similar approaches may be trialled in the Black Sea region. Nonetheless, extreme weather conditions in the offshore would require new concepts in structures' design, new materials, remote monitoring and higher automation to keep the capital and running cost of construction and operation within an economically viable range (Jensen et al, 2007). Offshore aquaculture may provide an additional and important contribution to the future development of aquaculture in the Black Sea, contributing to the resolution of possible future conflicts for ever more limited resources in coastal areas.

\subsubsection{Development and Demonstration Methodologies of Mollusc Production}

To date, mariculture concerns around the Black Sea have been focusing mainly on finfish species of high economic value (Massa et al., 2017), such as turbot and sturgeons, (Niță and Nenciu, 2017; Niță et al., 2018a), European seabass, gilthead seabream and trout (Report TR90, 2012). On the other hand, the Mediterranean mussel (Mytilus galloprovincialis, Lamarck, 1819) is a marine organism with a significant ecological and economic value in the Black Sea ecosystem. Mussel culture has been practiced in the Black Sea since the last century, however recent advanced studies, conducted to better understand this species physiology and ecology, have recently allowed for a rapid and significant technological advancement to be achieved (Niță et al, 2019).

In some countries in the region, mussel farming is fairly developed (Niță et al, 2019), and research activities on bivalve culture in the Black Sea have mostly focused on mussels and in particular site selection (Özsoy, 2017) and production systems (Karayücel et al., 2003; Karayücel et al., 2010) have been investigated. Importantly, studies have also focused on the importance of food hygiene during all key production, storage and distribution processes concluding that when production standards set by FAO / WHO are followed, bivalve farming will yield a healthy and marketable product (Niță et al., 2018b).

Mussels are filter-feeding bivalve molluscs that can accumulate different toxic substances including marine biotoxins in their tissues. The presence of biotoxins in shellfish can cause serious health concerns for consumers (Roșioru et al., 2012). Consequently, potentially harmful algal blooms (HAB) and bacterial outbreaks, with severe consequences for food safety and human health, are to be considered as a major external risk to developing mussel aquaculture. There are issues to consider while allocating spaces for any kind of marine aquaculture. In order to avoid conflicts of maritime space use and the difficulties related to mussel culture with other users of the marine and coastal environment, support in the implementation of special zones for mussel culture should be developed.

\subsubsection{Biotechnology \& Aquaculture (Micro \& Macro Algae)}

In recent years, a lot of effort has been made to promote sustainable aquaculture and to control pollution from wastewater, subsequently avoiding endangering aquatic life.

The most common and easy method of controlling pollution caused by aquaculture effluents is to remove potentially toxic compounds from the wastewater. These practices comprise traditional environmental remediation technologies such as aeration, filtration, and anaerobic-anoxic-oxic (A2O) system (Abyar et al., 2018; Adler et al., 2000; Altmann et al., 2016). However, all these systems increase aquaculture costs and nutrients such as nitrogen, phosphorus, and carbon in wastewater cannot be fully used and recycled (Longo et al., 2016). Microalgae that efficiently absorb nutrients from a nutrient-rich eutrophic body of water are known to be suitable for wastewater reclamation (Leng et al., 2018; Wang et al., 2015). At the same time, microalgae synthesize many economically valuable compounds such as proteins, lipids, and natural pigments (Lu et al., 2017; Ansari et al., 2017; Sirakov et al., 2017). The status of flora and fauna in the Black Sea is rapidly deteriorating due to domestic and industrial pollution (Sorensen et al., 1997; Zaitsev and Mamaev, 1997; Bakan and Büyükgüngör, 2000). Because the amount of organic matter spilled into the sea is more than the bacteria in seawater can normally decompose, bacteria obtain oxygen from sulphide ions, a component of seawater, rather than dissolved oxygen found in seawater. As a result of this process, hydrogen sulfide $\left(\mathrm{H}_{2} \mathrm{~S}\right)$ gas emerges and, in the Black Sea this prevents life to develop below 200 meters in depth.

Due to these unique set of environmental circumstances, unsustainable aquaculture activities in the Black Sea have the potential to contribute to the development of anoxic regions. Therefore, it is important that future aquaculture development is focused on low trophic and low impact species such as 
micro- and macroalgae. As in all aquatic environments, the algae found in the Black Sea are indispensable resources for countries with a coastline to the Black Sea, both ecologically and economically. However, no specific study on the potential for the culture of algae in the Black Sea has been carried out to date. Nonetheless, a total of 111 research studies have been conducted on algae biology in the Black Sea since 1996. According to these studies, the algae population of the Black Sea is very valuable both in terms of quality and quantity, but species diversity has decreased due to pollution. For this reason, aquaculture activities to be carried out in the Black Sea must be sustainable and environmentally friendly. In particular, studies conducted in the area have highlighted the importance of local algae species such as Ulva lactuca (Chlorophyceae), Cystoseira barbata (Phaeophyceae), and Ceramium rubrum (Florideophyceae) as potential source of compounds useful for the food, pharmaceutical, and cosmetic industries (Cadar et al., 2019). Nonetheless, other studies have identified the ability of algae such as Cystoseira sp. and Ulva sp. to bio-accumulate potential toxic compounds, such as heavy metals, and although this could presents a potential risk for consumers (Parus and Karbowska, 2020), it may also offer the possibility to use algae such as Ulva rigida, Punctaria latifolia, Pyropia leucosticta, Callithamnion corymbosum, and Cladophora sericea as a bioremediatory culture to reduce pollution from particularly polluting industries (Căpriţă and Ene, 2020). Within this field the interaction between algae, pollutants and environmental factors has also been investigated (Szeląg-Sikora et al., 2016; Negreanu-Pîrjol et al., 2011; Strezov and Nonova, 2005). Importantly, studies conducted in the Black Sea region have also investigated the potential of algae to generate green energy (Zlateva and Dimitrov, 2019). Additionally, algae represent a valuable tool to investigate and monitor the general health of the aquatic environment. Important research in the Black Sea region has been conducted to study changes in the seasonal and perennial dynamics of algae communities (Cadar and Cherim, 2018) and concluded that algae could serve as a natural indicator of environmental quality (Parus and Karbowska, 2020). Macro- and Microalgae are also constantly interacting with microorganisms and other toxic compounds in the sea, therefore interaction between pathogens, the environment (light) and algae has been studied over recent years to establish infections dynamics (Stelmakha and Stepanovab, 2020).

Among the theories developed to encourage the implementation of algae-supported integrated aquaculture, there are many systems such as microalgae-based nutrient assimilation, channel pool systems, revolving algal biofilm (RAB) system, wastewater pre-treatment methods and the establishment of algae-bacteria cooperation (Gross et al., 2015). Since algae-supported integrated aquaculture will eliminate both unusable excess feed and fish waste, it will make significant contributions to sustainable aquaculture, especially in an inland sea such as the Black Sea. Such development can also prevent eutrophication as it cleans the water from excess waste. However, despite advances in the fields mentioned in the literature, this innovation cannot be fully developed commercially due to the lack of knowledge on both economic feasibility and biomass safety level of algae, and life cycle analysis in algae-supported integrated aquaculture. However, as knowledge on these issues increase, bottlenecks will be resolved and algae will play a more important role in aquaculture for sustainable development.

\subsubsection{Potential Impacts of Climate Change on Aquaculture}

There is a worldwide consensus that the effects of climate change will affect environments, livelihoods and global food production including aquaculture activities in the near future, as stated by the Intergovernmental Panel on Climate Change (IPCC) latest report (IPPC, 2014).

Projected scenarios caused by a changing climate in the Mediterranean and the Black Sea comprise of relatively high temperature increase, lower precipitations and an increase in frequency and intensity of acute droughts and heatwaves (FAO, 2018f). These changes are also expected to interact with other ecosystem stressors and together they would impact the marine ecosystem, as well as change current fisheries and aquaculture practice (FAO, 2018f).

Black Sea surface water temperature has increased significantly during the last century (Ginzburg et al., 2004; Nardelli et al., 2010; Shapiro et al., 2010; Lebedev et al., 2017). This increase has both affected primary production and threatened fish stocks and marine fisheries resources (Brander, 2007; Cheung et al., 2009; Erdogan et al., 2009; Miheneva, 2018; Hidalgo, et al 2018). By 2100 the Black Sea is also expected to warm by $2.8^{\circ} \mathrm{C}$ and $0.5^{\circ} \mathrm{C}$ for summer and winter respectively (Barange et al., 2018).

Climate change will lead to significant alterations in the availability and trade of fish products, with potentially important economic and social costs, especially for those countries most dependent on aquatic resources, representing a serious threat for coastal communities and their livelihood. Currently, the changing climate has become one of the biggest existential threats for life on Earth (Jingchao \& Kotani, 2012).

The 2015 Paris Climate Agreement called for a collective response to take adaptation and mitigation measures to prevent expected impacts, including the melting of glaciers and rising seawater levels, a decrease in forests and agricultural areas, an increase in the frequency and severity of weather events, desertification, irregular precipitation, floods and hurricanes. Adverse conditions resulting from climate change create social and economic pressure on natural 
resources and ecosystems, that negatively affect food and livelihoods, reducing the variety and quantity of food (Lee and Dang, 2018; Jonsson and Jonsson, 2009). Carbon dioxide and other gases released into the atmosphere by humans have caused global warming by creating a greenhouse effect and noticeable changes in the chemical structure of the earth's atmosphere compared to $100-150$ years ago (Kılıç, 2008).

In addition to greenhouse gases, other pollutants entering the environment can contribute to climate change. For example, industrial pollutants discharged into waterways can cause eutrophication (Schiedek et al., 2007). Also, studies show that the sensitivity of many plants and animals to pollutants increases with temperature (Khan et al., 2006; Noyes et al., 2009). Temperature is also a factor affecting metal uptake and toxicity in aquatic organisms as it affects both the physiology of the organism and the chemistry of the metals in the environment (Sokolova and Lannig, 2008).

The warming of the oceans facilitates the methylation of mercury, increasing the methyl mercury uptake in fish and mammals by $3-5 \%$ per $1^{\circ} \mathrm{C}$ increase (Thomson and Rose, 2011). At high temperatures the oxygen in the water decreases while aquatic organisms' metabolic oxygen demand increases. As a consequence, breathing rate will increase together with the uptake of the pollutants dissolved in the water (Khan et al., 2006). The impacts of climate change on fisheries and aquaculture are therefore striking. Decreases in the $\mathrm{pH}$ of the North Atlantic (about $0.0035 \mathrm{pH}$ units per year for the last 30 years), in addition to forecasts of ongoing declines in the future, raise concerns about the potential impact on harvested shellfish (Telesca et al., 2019) and early life stages of some finfish species (FAO, 2018f).

The Arctic Research Commission predicts that by 2050, the glacial areas will have decreased approximately $40 \%$ by volume (Brass, 2002). This decrease will not only cause problems for living creatures due to reduction in the ice cover, but also because of the rise in seawater level caused by ice melting, which will cause floods, erosion and increased sediment transport (Sağlam et al., 2008).

IPCC (2019) reported that the global mean sea level (GMSL) had risen $0.16 \mathrm{~m}$ in 1902-2015 period, though the rise is not globally uniform and varies regionally. It is expected that the GMSL will continue to rise in the next centuries (IPCC, 2019), causing loss of land in coastal areas and salinization of arable land and freshwater wells (Mimura, 2013).

Furthermore, as the seawater temperature increases as a result of climate change, the annual temporary periods in which harmful algal blooms occur may be extended (Tirado et al., 2010). For example, in the North Sea and the North-East Atlantic, the number of toxic algae blooms has increased with the increase in temperature since the 1990s, and as a result of this increase, the algae decomposition caused deaths by reducing oxygen levels in the benthic region (Edwards et al., 2006).
Furthermore, blooms of harmful algae species in marine and coastal areas may increase (Moore et al., 2008; Llewellyn, 2010), causing a significant threat to wild and farmed shellfish (Braga et al., 2018).

In the Black Sea, jellyfish blooms can also directly affect fisheries by varying the fish larvae survival (Daskalov et al., 2007). In fact, jellyfish can negatively influence fish recruitment and as they can be venomous, outbreaks can also be harmful to aquaculture and have strong ecological and socio-economic impacts (Sabrié et al., 2016).

Adverse conditions occurring in marine and freshwater ecosystems due to climate change, may adversely affect the diversity, population, and nutritional value of fish (Hollowed et al., 2009). As environmental factors change, many fish species may leave their habitats and migrate to colder or deeper waters in search of a new habitat. As the water level in coastal zones rises, depending on the temperature, the lagoons, and marshes, which are the breeding and growth areas of crab, shrimp, and many economically important fish species, will disappear (Schiedek et al., 2007). The creatures that lay their eggs in these areas will lose their breeding places and sessile organisms such as mussels and oysters living in coastal areas may be exposed to more predators due to the rise of the water. Increasing water temperature and decreasing oxygen levels with the rising water level in the bays cause serious threat to fish. However, it is possible to enrich fisheries in many areas as the biological activity is higher at high temperatures. Aquatic organisms are particularly vulnerable to climate change because their metabolism is significantly affected by water temperature, salinity, and oxygen levels (Mol and Doğruyol, 2012).

Climate change can have a direct and/or indirect impact on aquaculture and expected potential effects depend on geographical location, farming system and species farmed and thus endanger food stability (IFAD, 2014; Froehlich et al., 2018) and some of them were already mentioned above in 2.4 and 2.6. To date, there is already a significant body of knowledge with regard to the biophysical impacts of climate change on aquatic and other ecosystems but less understanding on how people will be able to respond and adapt aquaculture production systems to cope with the emerging challenges. The latter calls for the urgent identification of suitable adaptation and mitigation measures in order to cope with these threats.

\subsubsection{Animal Health and Welfare}

In aquaculture activities, biosecurity risks and stock health concerns could arise that could be harmful to the aquatic environment and ecosystem, besides causing heavy losses to farmers. Farmed species are exposed to the spread of aquatic diseases and pathologies resulting from a combination of many internal and external factors. Internal factors include metabolic and 
endocrine disorders, organ degeneration, and tumours, etc. External factors that cause the disease are pathogenic factors (Toranzo et al., 2005) such as bacteria, viruses, fungi, parasites, and a weakening of the immune system due to physical-chemical factors, heating or cooling of water, poisoning events, vitamins and minerals deficiency (Magnusson et al., 1994; Austin and Austin, 1999; Herbst et al., 2001; Küçük and Yıldırım., 2001; Dorucu and Mutlu, 2008; Reith et al., 2008; Gelderen et al., 2011; Andreoni and Magnani, 2014; Rozas and Enriquez., 2014; Karlsen et al., 2017; Mishra et al., 2018; Mohamad et al., 2019).

Aquaculture activities in the Black Sea are no exception, and between 2006 and 2007, an extensive study was conducted by the Department of Fisheries Technology Engineering, Faculty of Marine Sciences, Karadeniz Technical University, Trabzon (Turkey) in 28 Oncorhynchus mykiss hatcheries to examine the presence and spread of viral fish pathogens in the Black Sea region (Ogut et al., 2013). As a result of the study, it was determined that the Infectious Pancreatic Necrosis Virus (IPNV) is an endemic disease, while neither the Infectious hematopoietic necrosis virus (IHNV) nor-viral haemorrhagic septicaemia virus (VHSV) was found in cultured rainbow trout. In the research, IPNV belonging to genogroup III was detected in more than half of the hatcheries in the region (Ogut et al., 2013). However, it was observed that the virulence of the isolates spread in the region was low for rainbow trout juveniles. If biosecurity protocols are not applied to prevent pathogens entry and spread, viruses like IPNV will be readily transmitted to other rainbow trout farms in the region (Ogut et al., 2013).

In another study, the bacterial population of 180 Merlangius merlangus euxinus caught on the eastern Black Sea coast of Turkey was characterised. In the study, the presence of Pseudomonas luteola, Staphylococcus equorum, Vibrio anguillarum, Pseudomonas putida, Acinetobacter johnsonii, Pseudomonas protogens, Oceanisphaera profunda, Pseudomonas fluorescens, and Serratia fonticola were determined (Ture et al., 2018). In Ukraine epidemiological and disease studies have been recently undertaken on rainbow trout, sturgeons, and African catfish (Heterobranchus bidorsalis) reared in RAS (GFCM, 2019).

The prevention and control of diseases outbreak is of uppermost importance at national and regional level. Each country should have its own aquaculture strategy for animal health issues which fall in a common action plan and harmonized approach for the Black Sea (GFCM, 2019). Aspects that must be considered in aquatic animal health and biosecurity plans include an effective health management measures based on epidemiological knowledge, the capacity to undertake an early diagnosis of pathogens in fish farms, application of effective biosecurity measures at the farm level, enhanced surveillance systems in place and the application of risk analysis approach (GFCM, 2019).

\subsection{The Covid-19 Emergency: A Global Threat}

The COVID-19 Emergency that appeared in early 2020 had a strong impact on fisheries and aquaculture food systems around the world and called for a series of emergency actions and responses (FAO, 2021). In the Black Sea it has had different impacts from country to country and type of farming systems. What has been in common to all is that the measures taken to contain the pandemic have affected the sector and the whole food value-chain system. The Covid-19 has brought havoc in the aquaculture industry in the Black Sea riparian countries, including the ancillary activities along the value chain. Though specific impacts might vary among the six countries, in general these included the dropping demand for fishery products also due to the decline of visiting tourists, the HoReCa sector being hit hard for the closures of retailers, bars, restaurants and cafés in compliance with the governmental requirements to contain the spread of virus. In the aftermath of the pandemic onset and subsequent outbreak waves, jobs were lost, prices fell, sourcing supplies including quality feed ingredients and equipment became difficult with a consequent increase in prices, logistics and all transports were drastically reduced including the delivery of products to overseas markets. Other issues also encompassed the storage of live fish as well as of frozen produce that could not be sold fresh, the access to financial instruments in support of enterprises became too slow and bureaucratic.

On the positive side, during the lockdown periods the demand for canned and frozen fishery products went up in the European markets, which was an advantage for processing enterprises based on the Black Sea riparian countries. Furthermore, the organization by producers of discounted seabass, seabream, portionsized rainbow trout, and Black Sea salmon sales in domestic markets supported farmers and improved their cash flows. In some instances, governments have set-up compensation schemes to support the sector while in some inland farms, the proposed recreational fishing activities offered an additional income to recover part of the lost revenues. Finally, farmers adopted also diversified measures to cope with the Covid-19 emergency through, among other things, novel feeding strategies, diversification of production, services of take-away and home delivery of fishery products.

\section{Conclusions}

The information collected and outlined in the present manuscript give a fresh look on aquaculture practised by countries bordering the Black Sea, scrutinizing the different topics and challenges that are considered and addressed by the scientists involved in the preparation of this review. Although not exhaustive, it could be a useful contribution to understand on how to unlock the potential of sustainable development aquaculture in the region. 
Aquaculture in all the Black Sea bordering countries has a long tradition, the first artificial reproduction of sturgeon started here during the last decades of the eighteenth century, and this species still represents the most iconic species in the sea. The sector as a whole, fresh water, brackish water, and marine activities, is of great importance for the area, mariculture in particular, has grown substantially during the past decade but it has still not reached its full potential despite the technical progress that have been made.

One aspect that it is evident and needs to be emphasized is that the Black Sea represents a single environment in terms of climate, human, historical, social, and ecological conditions and is far from being a homogenous system. Likewise, aquaculture development in the area requires specific actions as some areas presents specific challenges including the lack of suitable sheltered areas and low winter temperatures, which can endanger the harvest. These conditions for aquaculture development are also in part reflected in a different level of development between countries. Aquaculture endeavours around the Black Sea, are clearly adapted to the specificities of the two different coasts: the shallow, unsheltered and highly variable (in terms of salinity and temperature) north western shelf and the deep, more sheltered and stable south-eastern shelf.

The differences in production systems, technologies and farmed species, are representative of the countries' specificities, that many times reflect the history and climate conditions in the region. Environmental aspects have a critical impact on the development of farming systems. Due to the scarcity of sheltered areas, there are some difficulties to consider in aquaculture development in such areas (e.g. the allocation of space for cage culture), whereby marine land-based facilities, such as RAS, should be considered in particular for the North-Western part of the Black Sea. Aquaculture in the Black Sea needs a proactive sciencebased approach to ensure a sound development of the sector. Particularly in areas where innovative research and the use of technologies are either not yet or not fully developed, such as the uptake of integrated multitrophic aquaculture (IMTA), recirculation aquaculture system (RAS) and offshore aquaculture.

However, the Black Sea has great potential due to the characteristics of water resources, environmental characteristics and available technologies. For these reasons it is necessary that the local conditions are considered when aquaculture development is planned and that the areas are identified for farming activities. In this setting, countries have indeed progressed to adopt a specific plan for aquaculture development. It is now necessary to strengthen the institutional frameworks in relation to spatial planning and implementation of Allocated Zones for Aquaculture (AZA), that in many areas still need to be established beyond the single process of zonation. These must be considered as a management tools for the sound integration of aquaculture activities within marine spatial planning. The development of infrastructures in support of the development in the region is essential, and the establishment of AZA remains a priority, supported by a dedicated regulatory and administrative framework, addressing the dimensions of sustainability and to create an enabling the environment for further development and facilitate public and private investments.

Results from applied research also play an important role in facilitating the investment and boosting the sector. Scientific cooperation in the area and the sharing of knowledge should take advantage of the results of existing activities and projects.

Most riparian countries in the Black Sea have used aquaculture for restocking purposes both in inland and in marine waters. In the latter, restocking of turbot originated from the awareness of stakeholders and public and private sectors from all riparian countries on the depletion of wild stocks and the need to support recovery of this endangered species. This is a unique and rare characteristic of this region and additional effort could be done among the countries in sharing knowledge and strengthening cooperation in sustainable restocking to achieve a better and successful results.

Aquaculture in Black Sea is characterized by a limited number of species, and diversification would be the way to support aquaculture development in its riparian countries. It is of uppermost importance to develop appropriate farming techniques and methodologies based on solid scientific basis to ensure a successful production of the selected species, thus contributing to the expansion of the industry.

There is a great difference between countries in trade deficit, like Bulgaria, Romania and Ukraine, and countries that are net importers, such as the Russian Federation, Turkey and Georgia. Except for the Russian Federation, the apparent consumption per capita in countries are lower than the global average.

It is evident that development of aquaculture in the region would help countries to decrease the dependency from import of aquatic products. Such development should be fostered by national policies to encourage domestic consumption of aquatic products to prevent unstable supply and demand patterns. In this context national policies for aquaculture development targeting all nodes of the value chain would facilitate the sustainable development of the sector in the region, whilst the GFCM "Aquaculture Demonstrative Centers" and foreseen "Market Observatories" would be valuable instruments to enhance regional scientific, technical cooperation, and stakeholder consultations.

As in most of part of the word, climate change is impacting on the Black Sea as well. Effects include increase in water temperatures including, abnormal and unpredictable temperature peaks, natural disasters like storms and floods and the salinization of the Azov Sea. 
To date it appears that the shellfish sector could be impacted by a changing climate due to high temperatures conditions that affect the mussel's gonad maturation, the native mussel spat settlement and oyster growth. On the other hand, a future threat would be the invasion of thermophilic species of animals and plants and new pathogens. In this context there is an urgent need to further research on causes and effects of climate change on ecosystems and the whole aquaculture sector, and to identify and put in place mitigation and adaptation measures to be able to effectively cope with.

The development of aquaculture in the Black Sea could be drastically hampered by outbreak and spreading of transmissible diseases. In this respect, prevent and control diseases at national and regional level should be a priority and could be pursued through effective health management measures based on epidemiological knowledge, early diagnosis of pathogens in fish farms, application of effective biosecurity measures at the farm level, adaptive management, application of risk analysis and harmonized approach in the region to strengthen the surveillance systems.

Undoubtedly, the Covid-19 pandemic emergency commenced early 2020 has had a heavy impact on the aquaculture sector, reshaping the whole value chain balances among actors. The measures taken by countries to contain the rate of infection have directly and indirectly affected the sector through new sanitary measures, different consumer demands for seafood products, the access to domestic and international markets, business closures including the HoReCa, as well as logistical problems related to transportation and border restrictions. Several counter measures were adopted after the Covid-19 outbreak which, to some extent, provided some financial relief to the aquaculture value chain actors. However, due to the novelty of such pandemic situation, for the years to come it remains uncertain how the aquaculture sector would respond to cope with new challenges brought about the Covid-19 emergency, based on its resilience and adaptation capacity.

Sharing knowledge and exchange of experience are two aspects that could positively contribute to the further development of the sector. The marine aquaculture and brackish aquaculture have great potential, demonstrated by a shared interest among riparian countries to increasing cooperation in the region.

\section{Acknowledgements}

A special thanks to Aina Afanasjeva, the late director of EUROFISH International Organisation. With two Black Sea riparian countries, Romania and Turkey, as members of EUROFISH, she supported this project from the outset. She was instrumental in contributing to the manuscript and strengthening the cooperation in the region. We think she would have been happy with our portrayal of the opportunities and challenges of aquaculture in the Black Sea region.

\section{References}

Abyar, H.; Younesi, H.; Bahramifar, N.; Zinatizadeh, A.A. (2018). Biological CNP removal from meat-processing wastewater in an innovative high rate up-flow A2O bioreactor. Chemosphere, 213, 197-204.

Adamenko, T. (2014). Agroclimatic zoning of the territory of Ukraine taking into account climate change. Kyiv.

Adamenko, T. (2019). Climate change and rural economy in Ukraine: what should farmers know? s.l.: GermanUkrainian agro-political dialogue.

Adler, P.R.; Harper, J.K.; Takeda, F.; Wade, E.M.; Summerfelt, S.T. (2000). Economic evaluation of hydroponics and other treatment options for phosphorus removal in aquaculture effluent. HortScience, 35, 993-999.

Aguado-Giménez, F., Carballeira Ocaña, A., Collado Sánchez, C. (2012). Propuesta metodológica para la realización de los planes de vigilancia ambiental de los cultivos marinos en jaulas flotantes. Junta Nacional Asesora de Cultivos Marinos (JACU-MAR). Ministerio de Agricultura, Alimentación y Medio Ambiente, Spain, 164 p.

Aguilar-Manjarrez, J., Soto, D. \& Brummett, R. (2017). Aquaculture zoning, site selection and area management under the ecosystem approach to aquaculture. A handbook. Report ACS18071. Rome, FAO, and World Bank Group, Washington, DC. 62 pp. Includes a USB card containing the full document (395 pp.).

Ak, K., Kurtoğlu, İ., Serezli, R., Kayış, Ş., Yandı, i. (2019). Introduce the Siberian Sturgeon (Acipenser baerii) to Turkish aquaculture industry: Duoculture possibility with Rainbow Trout. Ege Journal of Fisheries and Aquatic Sciences, 36 (3), 211-217. https://doi.org/10.12714/egejfas.2019.36.3.02.

Ak, O., Ceylan, B., Aydın, İ., Polat, H., Küçük, E., Eroğlu, O., \& Kapiris, K. (2016). Stock enhancement by hatcheryreleased turbot, Psetta maxima, in the southeastern Black Sea: capture, migration, growth and diet analyses. Scientia Marina, 80(2), 163-174.

Akbulut, B. (1998). Research on Cultivation Systems Applicable in Bringing Rainbow Trout to Fillet Weight Under Eastern Black Sea Conditions. Doctoral Thesis. Fisheries Technology Engineering, Institute of Science, Karadeniz Technical University.

Akbulut, B. \& Şahin, T. (1999). Effect of weight loss occurring in winter season on growth of seabass (Dicentrarchus labrax) reared in the Black Sea, Turkish Journal of Marine Sciences, 5, 39-46.

Akbulut B., Kurtoğlu i.Z., Üstündağ E., Aksungur M. (2009a). Historical development and future projection of aquaculture in the Black Sea region. Journal of Fisheries Sciences, 3 (2), 76-85.

Akbulut, B., Zengin, M., Dağtekin, M., Özkan, B., Eroglu, O., Çiftci, Y., Firidin, Ş., Cakmak, E., Çavdar, Y., Aksungur, N., Aydın, i., Ustaoglu Tiril, S., Memis, D., Alkan, A., Üstündag, E. ve Serdar, S. (2009b). Present Status of Sturgeon Population and Rearing Possibilities in Turkish Black Sea Coastline and Rivers. The $6^{\text {th }}$ International Symposium on Sturgeon Wuhan, Hubei Province, China.

Akbulut, B., Zengin, M., Çiftçi, Y., Ustaoğlu Tiril, S., Memiş, D., Alkan, A., \& Eroğlu, O. (2011). Stimulating sturgeon conservation and rehabilitation measures in Turkey: an 
overview on major projects (2006-2009). Journal of Applied Ichthyology, 27(2), 415-419.

Akbulut, B. \& Aydın, í. (2012). Future predictions and current status of Sturgeon. Symposium of Freshwater Fisheries, Ondokuzmayıs. November 9, 2012 Ondokuzmayıs Samsun (In Turkish).

Akbulut, B., Feledi, T., Lengyel, S., \& Ronyai, A. (2013). Effect of feeding rate on growth performance, food utilization and meat yield of sterlet (Acipenser ruthenus Linné, 1758). Journal of Fisheries Sciences, 7(3), 216.

Alkan, A., Akbulut, B., Başçinar, S., Zengin, B., Serdar, S. (2006). Determination of the effects of aquaculture establishments on marine ecosystem. Aquaculture Studies (Old Dolphin Research Bulletin) (1).

Altmann, J., Rehfeld, D., Träder, K., Sperlich, A., Jekel, M. (2016). Combination of granular activated carbon adsorption and deep-bed filtration as a single advanced wastewater treatment step for organic micropollutant and phosphorus removal. Water Research, 92, 131-139.

Alpbaz, A.G. (1990). Sea Fish Aquaculture. Aegean University Fisheries College No:20, Izmir, 335 pp. (in Turkish).

Andreoni, F. and Magnani, M. (2014). Photobacteriosis: Prevention and Diagnosis. Hindawi Publishing Corporation Journal of Immunology Research, 793817, 7. https://doi.org/10.1155/2014/793817

Ansari, F.A., Singh, P., Guldhe, A., Bux, F. (2017). Microalgal cultivation using aquaculture wastewater: Integrated biomass generation and nutrient remediation. Algal Research, 21, 169-177.

Attramadal, K.J.K., Salvesen, I., Xue, R., Øie, G., Størseth, T.R. Vadstein, O., Olsen, Y. (2012). Recirculation as a possible microbial control strategy in the production of marine larvae. Aquaculture Engineering, 46, 27-39.

Austin, B. \& Austin, D.A. (1999). Bacterial Fish Pathogens. Diseases of Farmed and Wild Fish. Springer-Praxis Publishing, Ltd., United Kingdom.

Aydın, I., Küçük, E., Şahin, T., Kolotoğlu, L. (2011a). The effect of feeding frequency and feeding rate on growth performance of juvenile Black Sea Turbot (Psetta maxima, Linneaus, 1758). Journal of Fisheries Scienes, 5(1), 35-42. https://doi.org/10.3153/jfscom.2011004

Aydın, i., \& Şahin, T. 2011b. Reproductive performance of turbot (Psetta maxima) in the south-eastern Black Sea. Turkish Journal of Zoology, 35(1), 109-113.

Aydın, I., Polat, H., \& Şahin, T. (2020). Reproductive Performance of Wild and Hatchery-Reared Black Sea Turbot, Psetta maxima, in the Southern Black Sea Coast. Turkish Journal of Fisheries and Aquatic Sciences, 20, 351-357. https://doi.org/10.4194/1303-2712-v20_5_03

Barazi-Yeroulanos, L. (2010). Synthesis of Mediterranean marine finfish aquaculture - a marketing and promotion strategy. Studies and Reviews. General Fisheries Commission for the Mediterranean. No. 88 Rome, FAO. 198p.

Bakan, G. and Büyükgüngör, H. (2000). The Black Sea. Marine Pollution Bulletin, 41.1-6, 24-43. https://doi.org/10.1016/S0025-326X (00)00100-4

Baltadakis, A., Casserly, J., Falconer, L., Sprague, M., Telfer, T.C. (2020). European lobsters utilise Atlantic salmon wastes in coastal integrated multi-trophic aquaculture systems. Aquacult Environ Interact, 12, 485-494. https://doi.org/10.3354/aei00378

Barange, M., Bahri, T., Beveridge, M.C.M., Cochrane, K.L., Funge-Smith, S. \& Poulain, F., eds. (2018). Impacts of climate change on fisheries and aquaculture: synthesis of current knowledge, adaptation and mitigation options. FAO Fisheries and Aquaculture Technical Paper No. 627. Rome, FAO. 628 pp.

Barbukho, O. (2016). Ecological-Toxicological Assessment of the Desna River and Adjacent Floodplain Lakes (within the Chernigiv Region, Ukraine) in Terms of Pesticides Content in Fish Liver. Hydrobiological Journal, 52(2), 109120.

Bascinar, N.S., Gozler, A.M., Şahin, C., Eruz, C., Tolun L., Agirbas E., Verep, B. (2014). The impact assessment of cage aquaculture on benthic communities along the southeastern Black Sea. Iranian Journal of Fisheries Sciences, 13(3), 719-738.

Beken, A.T., Polat, H., Aydın, I. (2014). Cryopreservation of Turbot (Psetta maxima) Sperm with Different Cooling Protocols, September 25-27, 2014, International Symposium on Fisheries and Aquatic Sciences (FABA 2014), Trabzon, Turkey.

Bersan, T. \& Sytnik, Y. (2013). Biodiversity and the role of animals in ecosystems: Proceedings of the VII International Scientific Conference. Dnepropetrovsk, Adverta, pp. 78-81.

Black Sea Commission. (2008). State of the Environment of the Black Sea (2001 - 2006/7).

Black Sea Commission. (2019). Commission on the Protection of the Black Sea Against Pollution. The Black Sea. Retrieved July 2020 from

http://www.blackseacommission.org/The\%20Black\%20Sea/Geography/

Black Sea CONNECT. (2020). Retrieved Oct 2, 2020 from http://connect2blacksea.org/

Bondar, O., Ryzhenko, N., Fedorenko, Y. \& Strilets, R. (2020). Dangerous properties of polychlorinated biphenyls and environmentally sound management of PCB in Ukraine. Regulatory Mechanisms in Biosystems, 11(1), 37-44.

Braga, A.C., Camacho, C., Marques, A., Martínez, A.G., Pacheco, M., Costa, P.R. (2018). Combined effects of warming and acidification on accumulation and elimination dynamics of paralytic shellfish toxins in mussels Mytilus galloprovincialis. Environmental Research, 164, 647-654.

Brander, K.M. (2007). Global fish production and climate change. Proceedings of the National Academy of Sciences of the United States, 104 (50), 19709-19714. Montenegrina, 14, 14-20. https://doi.org/10.1073/pnas.0702059104

Brass, G.W., Ed. (2002). The Arctic Ocean and Climate Change: A Scenario for The Us Navy. Arctic Ocean Climate Change, US Arctic Research Commission Special Publication No. 02-1, Arlington, VA, 14p.

BSGM. (2020). Statistics of Turkish Fisheries, Ministry of Agriculture in Turkish. Retrieved Nov 8, 2020 from https://www.tarimorman.gov.tr/sgb/Belgeler /SagMenuVeriler/BSGM.pdf.

Buhlak, Y., Guillotreau, P., Vallee, T., le Bihan, V., \& J.A. Theodorou, J.A. (2021). Multidimensional aquaculture investor index: Black Sea riparian countries. Journal of Applied Aquaculture. https://doi.org/10.1080/10454438.2021.1887040

Cadar, E. and Cherim, M. (2018). Studies on the physicochemical characteristics of the marine algae ecosystem from the Romanian Black Sea. Journal of Science and Arts, 3(44), 717-726.

Cadar, E., Axinte, E.R. Amzoiu, M., Jurja, S., Cherim, M. (2019). Preliminary study on the marine algae from the 
Romanian Black Sea Coast. Journal of Science and Arts, 4(49), 989-1000.

Caddy, J.F. (1993). Contrast between recent fishery trends and evidence for nutrient enrichment in two large marine ecosystems: The Mediterranean and Black Seas. In: Sherman, K., Alexander, L.M., Gold, B.D. (Eds.), Large Marine Ecosystems: Stress, Mitigation, and Sustainability. AAAS Press, Washington, D.C, pp. 137147.

Çakmak, E., Kurtoğlu, i.Z., Okumuş, i., Çavdar, Y., Aksungur, N., Firidin, Ş., Başçınar, N., Aksungur, M., Zengin, B., Ak, O., Esenbuğa, H. (2007). Culture of Black Sea Trout (Salmo trutta labrax Pallas, 1811) and it's use for restocking purposes, Central Fisheries Research Institute (SUMAE) Project Report (TAGEM/HAYSÜD/2001/07/01/20), 224s. (In Turkish)

Çakmak, E., Çankırılıgil, E.C., \& Özel, O.T. (2018). The Fifth Culture Generation of Black Sea Trout (Salmo trutta labrax): Culture Characteristics, Meat Yield and Proximate Composition. Ege Journal of Fisheries and Aquatic Sciences, 35(1), 103-110. https://doi.org/10.12714/egejfas.2018.35.1.16

Can, E, Kayim M., Kizak, V., Güner, Y. (2010). Sustainable aquaculture with environmental approaches. World Universities Congress, Conference paper, Çanakkale Turkey, P, 7.

Can, E. Kurtoglu, I.Z. Benzer, F., Erisir M., Kocabas, M., Kizak, V., Kayım, M., Çelik, H.T. (2012). The effects of different dosage of kefir with different durations on growth performances and antioxidant system in the blood and liver tissues of Çoruh trout (Salmo coruhensis), Turkish Journal of Fisheries and Aquatic Sciences, 12.

Căpriţă, F.C. and Ene, A. (2020). Biosorption of heavy metals from the metallurgical industry wastewater by macroalgae. AIP Conference Proceedings 2218, 030011 (2020); Published Online: 20 March 2020. https://doi.org/10.1063/5.0001087

Carras, M.A., Knowler, D., Pearce, C.M., Hamer, A., Chopin, T., Weaire, T. (2019). A discounted cash-flow analysis of salmon monoculture and Integrated Multi-Trophic Aquaculture in eastern Canada. Aquaculture Economics and Management, 43-63. https://doi.org/10.1080/13657305.2019.1641572

Caruso, F. (2018). Identification of the potentialities integrated multi-trophic aquaculture (IMTA) in the Mediterranean and Black Sea. MSc Thesis, Universidad de Las Palmas de Gran Canaria.

Chary, K., Aubin, J., Sadoul, B., Fiandrino, A., Covès, D., Callier, M.D. (2020). Integrated multi-trophic aquaculture of red drum (Sciaenops ocellatus) and sea cucumber (Holothuria scabra): assessing bioremediation and lifecycle impacts. Aquaculture, 516, 734621. https://doi.org/10.1016/J.AQUACULTURE.2019.734621

Cheung, W.W.L., Lam, V.W.Y., Sarmiento, J.L., Kearney, K., Watson, R. And Pauly, D. (2009). Projecting global marine biodiversity impacts under climate change scenarios. Fish and Fisheries, 10 (3), 235-251. https://doi.org/10.1111/j.1467-2979.2008.00315.x

Chia, E., Rey-Valette, H., Lazard, J., Clément, O., \& Mathe, S. (2009). Évaluer la durabilité des systèmes et des territoires aquacoles : proposition méthodologique. Cahiers Agricultures, 18(2-3), 211-219. https://doi.org/10.1684/agr.2009.0298

Chopin, T., Cooper, J.A., Reid, G., Cross, S., Moore, C. (2012). Open-water integrated multi-trophic aquaculture: environmental biomitigation and economic diversification of fed aquaculture by extractive aquaculture. Reviews in Aquaculture, 4, 209-220. https://doi. org/10.1111/j.1753-5131.2012.01074. x

Çiftci, Y., Eroğlu, O., \& Firidin, Ş. (2013). Mitochondrial cytochrome $b$ sequence variation in three Sturgeon species (A. stellatus Pallas, 1771, A. gueldenstaedtii Brandt, 1833, H. huso Linnaeus, 1758) from the Black Sea Coasts of Turkey. Turkish Journal of Fisheries and Aquatic Sciences, 13(2), 291-303.

Çoban, D., Demircan, M.D. \& Tosun, D.D. (Eds.) (2020). Marine Aquaculture in Turkey: Advancements and Management. Turkish Marine Research Foundation (TUDAV). Publication No: 59, İstanbul, Turkey.

Cristea, V., Suciu, R., lonescu, T. et al. (2016). Final Scientific Report of the Pilot Project no. 18/22.04.2013 “Assessing the survival and dispersion in the Black Sea of critically endangered sturgeon juveniles released in the Romanian Lower Danube 2013 - 2015", funded through the European Fisheries Fund/ Operational Programme for Fisheries Management Authority,

https://www.ddni.ro/sturgeons/images/Files/rapstprpil ot2013.pdf

Daskalov, G.M., Grishin, A., Rodionov, S., Mihneva, V. (2007). Trophic cascades triggered by overfishing reveal possible mechanisms of ecosystem regime shifts. Proceedings of the National Academy of Sciences, 104, 10518-10523.

Devine, D. (2005). Carlsbad hatchery group proposes offshore aquaculture on oil platform. Retrieved June 16, 2021 from https://www.sandiegouniontribune.com/sdutcarlsbad-hatchery-group-proposes-offshore-2005jun19story.html

Dimoftache, G. (1986). Experimental Culture Techniques Rearing the Common Shrimp Palaemon adspersus Rathke, 1836. Mariculture Issues, IRCM Constanţa, Romania: 77-86.

Dobrjanska, A., Melnik, A., Syariy, B. \& Korilyak, M. (2014). A comparative description of the ecological state of nursery ponds of the Lviv fish farm. Rybohospodarska Nauka Ukrainy, 2, 14-21.

Dorucu, M. and Mutlu, N. (2008). Parasitic Fish Disease and Their Treatment. e-Journal of New World Sciences Academy, 3 (2).

EAFA (2020). Annual report of Bulgaria on the efforts in achieving a sustainable balance between fisheries and fishing opportunities. pp. 37.

EC. (2018). High Level Conference on Black Sea Fisheries and Aquaculture. Sofia Ministerial Declaration. 7 June 2018. Sofia.

ECOAST. (2020). European MSP Platform. Retrieved Oct 3, 2020 from https://www.msp-platform.eu/projects/ecoast-newmethodologies-ecosystem-approach-spatial-andtemporal-management-fisheries

Edwards, D. \& Doroshov, S. (1989). Sturgeon and Seatrout Fisheries Development, FAO, Turkey Technical Cooperations Programme.

Edwards, M., Johns, D.G., Leterme, S.C., Svendsen, E., Richardson, A.J. (2006). Regional climate change and harmful algal blooms in the northeast Atlantic. Limnology and Oceanography, 51 (2), 820-829. https://doi.org/10.4319/lo.2006.51.2.0820

Edwards, P. (2015). Aquaculture environment interactions: Past, present and likely future trends. Aquaculture, 447, 2-14. 
https://doi.org/10.1016/j.aquaculture.2015.02.001.

Ehler, C. \& Douvere, F. (2009). Marine spatial planning: a stepby-step approach toward ecosystem-based management. Intergovernmental Oceanographic Commission and Man and the Biosphere Programme. IOC Manual and Guides No. 53, ICAM Dossier No. 6. Paris, UNESCO. Retrieved from

http://unesdoc.unesco.org/images/0018/001865/1865 59e.pdf

Elliott, J.M. (1994). Quantitative ecology and the brown trout. Oxford Univ. Press, Oxford, 286p.

Erdogan, N., Duzgunes, E., Ogut, H. (2009). Black Sea fisheries and climate change. In CIEMS Workshop Monographs June 2009. Retrieved from https://www.researchgate.net/publication/261709237 BBlack_Sea_fisheries_and_climate_change

Espinal, C.A and Matulić, D. (2019). Recirculating Aquaculture Technologies. pp 35-76 In: Aquaponics Food Production Systems. Combined Aquaculture and Hydroponic Production Technologies for the Future, 619.

EEA (European Environment Agency). (2015). The European Environment: State and Outlook 2015: Black Sea Region Briefing. Publications Office of the European Commission.

EU Directive 2014/89/EU. (2020). EUR-Lex, Access to European Union law. Retrieved Oct 3, 2020 from http://data.europa.eu/eli/dir/2014/89/oj

EU. (2019). European Union- Stakeholder Seminar on Blue Economy Towards a Common Maritime Agenda for the Black Sea. Istanbul, Turkey, March 2019.

European Commission. (2020). The EU Blue Economy Report. 2020. Publications Office of the European Union. Luxembourg.

European Regional Downscaling Experiment. (2020). EUROCORDEX. Retrieved Oct 15, 2020 from https://www.euro-cordex.net/

FAO. (2005-2021). National Aquaculture Sector Overview. Russian Federation. National Aquaculture Sector Overview Fact Sheets. Text by Bogeruk, A. In: FAO Fisheries Division [online]. Rome. Updated. Retrieved April 8, 2021.

FAO. (2012-2021). National Aquaculture Legislation Overview. Turkey. National Aquaculture Legislation Overview Fact Sheets. Text by DOffay, B. In: FAO Fisheries Division [online]. Rome. Updated. Retrieved May 26, 2021.

FAO. (2013). Applying spatial planning for promoting future aquaculture growth. Seventh Session of the SubCommittee on Aquaculture of the FAO Committee on Fisheries. St Petersburg, Russian Federation, 7-11 October 2013.

FAO. (2014). Committee on Fisheries. 2014. Report of the seventh session of the Sub-Committee on Aquaculture. St Petersburg, Russian Federation, 7-11 October 2013. FAO Fisheries and Aquaculture Report. No. 1064. Rome, FAO. $53 \mathrm{pp}$

FAO. (2015). Fishery and Aquaculture Country Profile: Georgia. Fisheries and Aquaculture Department. Retrieved April 2, 2021 from http://www.fao.org/fishery/facp/GEO/en/

FAO. (2016). Report of the first session of the COFI Advisory Working Group on Aquatic Genetic Resources and Technologies, Brasilia, Brazil, 1-2 October 2015. FAO Fisheries and Aquaculture Report No. R1139. Rome, Italy.

FAO. (2017). GFCM High-level conference towards enhanced cooperation on Black Sea fisheries and aquaculture: A declaration to boost regional cooperation in the sector, 24-25 October 2016, Bucharest, Romania. FAO Fisheries and Aquaculture Proceedings No. 52. Rome, Italy.

FAO. (2018a). The State of World Fisheries and Aquaculture: Meeting the Sustainable Development Goals. Food and Agriculture Organization of the United Nations, Rome.

FAO. (2018b). Regional Conference on building a future for sustainable small scale fisheries in the Mediterranean and the Black Sea, 7-9 March 2016, Algiers, Algeria. Fisheries and Aquaculture Proceedings No. 58. Rome. Italy

FAO. (2018c). Report of the forty-first session of the General Fisheries Commission for the Mediterranean (GFCM), Budva, Montenegro, 16-20 October 2017. GFCM Report No. 41. Rome, Italy.

FAO. (2018d). Report of the second session of the COFI Advisory Working Group on Aquatic Genetic Resources and Technologies, Rome, Italy, 19-20 October 2017. FAO Fisheries and Aquaculture Report No. R1224. Rome, Italy.

FAO. (2018e). National Aquaculture Sector Overview: Ukraine. National Aquaculture Sector Overview Fact Sheets. Text by Bekh, V. In: FAO Fisheries Division, Rome. Updated $17 / 07 / 2017$.

FAO. (2018f). Report of the Expert Meeting on Climate Change Implications for Mediterranean and Black Sea Fisheries. Rome, 4 to 6 December 2017. Fisheries and Aquaculture Report No. 1233. Rome, Italy.

FAO (2018g). The State of Mediterranean and Black Sea Fisheries. General Fisheries Commission for the Mediterranean. Rome. 172 pp. Licence: CC BY-NC-SA 3.0 IGO.

FAO. (2019a). The State of the World's Biodiversity for Food and Agriculture, J. Bélanger \& D. Pilling (eds.). FAO Commission on Genetic Resources for Food and Agriculture Assessments. Rome. 572 pp. Retrieved from http://www.fao.org/3/CA3129EN/CA3129EN.pdf

FAO. (2019b). Project report "Contribution to the technical and policy support of the Ministry of Agrarian Policy and Food of Ukraine (MAPF) for the implementation of the Strategy for Agriculture and Rural Development 20162020" (GCP/UKR/001/NOR), Rome, Italy.

FAO. (2020a). The State of World Fisheries and Aquaculture 2020. Sustainability in action. Rome. https://doi.org/10.4060/ca9229en

FAO. (2020b). The State of Mediterranean and Black Sea Fisheries 2020. General Fisheries Commission for the Mediterranean. Rome. https://doi.org/10.4060/cb2429en

FAO. (2020c). Fishery and Aquaculture Statistics. Global aquaculture production 1950-2018 (FishstatJ). In: FAO Fisheries and Aquaculture Department [online]. Rome. Updated 2020. Retrieved from www.fao.org/fishery/statistics/software/fishstatj/en/

FAO. (2021). The impact of COVID-19 on fisheries and aquaculture food systems, possible response, Information paper, November 2020. Rome. Retrieved from http://www.fao.org/documents/card/es/c/cb2537en/

Fitzer, S., Phoenix, V., Cusack, M. \& Kamenos N.A. (2014). Ocean acidification impacts mussel control on biomineralisation. Scientific Reports, 4, 6218. https://doi.org/10.1038/srep06218

Fodchenko, I.A. (2017). Comparative analysis of pesticide quantity in bivalve mollusks in Ukraine and other 
countries of the world. Bulletin of Summy National Agrarian University: scientific journal, 11 (41), 65-70. Retrieved from http://repo.snau.edu.ua/handle/123456789/6458/

Fossberg, J., Forbord, S., Broch, O.J., Malzahn, A.M., Jansen, H., Handå, A., Førde, H., Bergvik, M., Fleddum A.L., Skjermo J., Olsen Y. (2018). The Potential for Upscaling Kelp (Saccharina latissima) Cultivation in Salmon-Driven Integrated Multi-Trophic Aquaculture (IMTA). Frontiers in Marine Science, 5, 418. https://doi.org/10.3389/fmars.2018.00418

Fontaine, P., Legendre, M., Vandeputte, M., \& Fostier, A. (2009). Domestication de nouvelles espèces et développement durable de la pisciculture. Cahiers Agriculture, 18(2-3), 119-124. https://doi.org/ 10.1684/agr.2009.0293

Fourdain, L., Hamza, H., Bourdenet, D. \& Massa, F. (2019). Capacity-building on allocated zones for aquaculture in the Mediterranean and the Black Sea FAO Aquaculture Newsletter No. 60, August 2019: 24-25, Retrieved from http://www.fao.org/3/ca5223en/ca5223en.pdf

Friedrich, J., Dinkel, C., Friedl, G., Pimenov, N., Wijsman, J., Gomoiu, M.T., Cociasu, A., Popa, L., Wehrli, B. (2002). Benthic nutrient cycling and diagenetic pathways in the North-western Black Sea. Estuarine, Coastal and Shelf Science, 54 (3), 369-383.

https://doi.org/10.1006/ecss.2000.0653

Froehlich, H.E., Gentry, R.R. and Halpern, B.S. (2018). Global change in marine aquaculture production potential under climate change. Nature, Ecology \& Evolution, 2, 1745-1750. https://doi.org/10.1038/s41559-018-0669-1

FSA. (2015). Information on the status of fishery sector of Ukraine. Retrieved from https://darg.gov.ua/files/1/infodovidka_ribcomplecs.pdf

FSA. (2019). Overview of aquaculture production in Ukraine based on statistical form 1-A fish (annual) for year 2019 by Fisheries State Agency of Ukraine. s.l.: s.n.

Gelderen, R., Carson, J., Nowak, B. (2011). Experimentally induced marine flexibacteriosis in Atlantic salmon smolts Salmo salar. II. Pathology. Diseases of Aquatic Organisms, 95, 125-135.

https://doi.org/10.3354/dao02329

Geldiay, R. \& Balık, S. (1996). Turkey freshwater fish (Textbook) II. Printing. Ege University Faculty of Fisheries Publications No: 46, Textbook Index No: 16, Ege University Press house, Bornova- İzmir, $532 \mathrm{~s}$.

GFCM. (2012). Resolution GFCM/36/2012/1 on guidelines on Allocated Zones for Aquaculture (AZA). Retrieved from http://bit.ly/Resolution-GFCM-36-2012-1

GFCM. (2018). Resolution GFCM/41/2017/1 on a strategy for the sustainable development of Mediterranean and Black Sea aquaculture. In: FAO. 2018. Report of the fortyfirst session of the General Fisheries Commission for the Mediterranean (GFCM), Budva, Montenegro, 16-20 October 2017. GFCM Report No. 41. Rome, Italy.

GFCM. (2019). Report of the workshop on animal health and risk analysis in finfish aquaculture, Larnaca, Cyprus, 3-4 October 2018. Eleventh Session of the Scientific Advisory Committee on Aquaculture (CAQ), Malaga, Spain, 10-12 September 2019. Unpublished report.

Ginzburg, A.I., Kostianoy, A.G. and Sheremet, N.A. (2004). Seasonal and inter-annual variability of the Black Sea surface temperature as revealed from satellite data (1982-2000). Journal of Marine Systems, 52 (1-4), 3350. https://doi.org/10.1016/j.jmarsys.2004.05.002
Gokalp, M., Kuehnhold, H., de Goeij, J.M. and Osinga, R. Depth and turbidity affect in situ pumping activity of the Mediterranean sponge Chondrosia reniformis (Nardo, 1847) (2020). Preprint.

Golumbeanu, M., Nicolaev, S. (editors) (2015). Study on Integrated Coastal Zone Management. Ex Ponto Publishing, Constanta, ISBN 978-606-598-397-7: 454 p.

Goradze, R., Komakhidze, A., Goradze, I. (2013). The Channel Catfish in Georgian Aquaculture. Journal of Life Sciences, 7 (5), 532-538.

Goradze, R., Komakhidze, A., Mgeladze, M., Goradze, I., Diasamidze, R., Mikashavidze, E., Komakhidze, G. (2014). Importance of the Ecosystem Approach to Fisheries in Georgia. Importance of the Ecosystem Approach to Fisheries in Georgia. In: Lleonart J., Maynou F. (eds), The Ecosystem Approach to Fisheries in the Mediterranean and Black Seas. Scientia Marina, 78 (1), 111-115.

Gross, M., Mascarenhas, V., Wen, Z. (2015). Evaluating algal growth performance and water use efficiency of pilotscale revolving algal biofilm (RAB) culture systems. Biotechnology and Bioengineering, 112(10), 2040-50. https://doi.org/10.1002/bit.25618

Grosso, L., Rakaj, A., Fianchini, A., Morroni, L., Cataudella, S., Scardi, M. (2021) Integrated Multi-Trophic Aquaculture (IMTA) system combining the sea urchin Paracentrotus lividus, as primary species, and the sea cucumber Holothuria tubulosa as extractive species. Aquaculture, 534, 736268.

https://doi.org/10.1016/j.aquaculture.2020.736268

Gucu, A.C. (2002). Can overfishing be responsible for the successful establishment of Mnemiosis leidyi in the Black Sea? Estuarine, Coastal and Shelf Science, 54, 439-451.

Harvey, B., Soto, D., Carolsfeld, J., Beveridge, M. \& Bartley, D.M. (2017). Planning for aquaculture diversification: the importance of climate change and other drivers. FAO Technical Workshop, 23-25 June 2016, FAO Rome. FAO Fisheries and Aquaculture Proceedings No. 47. Rome, FAO. 166 pp.

Herbst, L.H., Costa, S.F., Weiss, L.M., Johnson, L.K., Bartell, J., Davis, R., Walsh, M., Levi, M. (2001). Granulomatous skin lesions in Moray eels caused by a novel Mycobacterium species related to Mycobacterium triplex. Infection and Immunity, 69, 4639- 4646.

Hidalgo, M., Mihneva, V., Vasconcellos M., and Bernal M. (2018). Climate change impacts, vulnerabilities, and adaptations: Mediterranean Sea and the Black Sea marine fisheries. In In book: Impacts of Climate Change on fisheries and aquaculture: Synthesis of current knowledge, adaptation, and mitigation options Editors: Manuel Barange, Tarub Bahri, Malcom Beveridge, Kevern Cochrane, Simon Funge-Smith, Florence Poulai. FAO Fisheries and Aquaculture Technical Paper No. 627(pp. 139-158).

Hollowed, A.B., Bond, N.A., Wilderbuer, T.K., Stockhausen, W.T., A'mar, Z.T., Beamish, R.J., Overland, J.E., Schirripa, M.J. (2009). A framework for modelling fish and shellfish responses to future climate change, ICES Journal of Marine Science, 66, 1584-1594. https://doi.org/10.1093/icesjms/fsp057

Holoștenco D.N., Onără D., Suciu R., Honț Ș., Paraschiv M. (2013). Distribution and genetic diversity of sturgeons feeding in the marine area of the Danube Delta Biosphere Reserve, Romania. Scientific Annals of the Danube Delta Institute, 19, 25-34.

Holoștenco D.N., Ciorpac M., Paraschiv M., Iani M., Honț Ș., 
Taflan E., Suciu R., Rîșnoveanu G. (2019), Overview of the Romanian Sturgeon Supportive Stocking Programme in the Lower Danube River System. Scientific Annals of the Danube Delta Institute, 24, 21-30. https://doi.org/10.7427/DDI.24.03

Huyben, D., Bevan, D., Stevenson, R., Zhou, H., Moccia, R. (2018). Evaluation of membrane filtration and UV irradiation to control bacterial loads in recirculation aquaculture systems. Aquaculture International, 26, 1531-1540. https://doi.org/10.1007/s10499-018-0301-z

ICZM. (2020). The Commission on the Protection of the Black Sea Against Pollution. Guidelines on Integrated Coastal Zone Management in the Black Sea.

Retrieved Nov 8, 2020 from http://www.blackseacommission.org/Downloads/Black_Sea_ICZM_Guidelin e/Black_Sea_ICZM_Guideline.pdf

IFAD. (2014). Guidelines for Integrating Climate Change Adaptation into Fisheries and Aquaculture Projects. 68pp.

Innal, D. \& Erk'akan, F. (2006). Effects of exotic and translocated fish species in the inland waters of Turkey. Reviews in Fish Biology and Fisheries, 16, 39-50.

Ioniță, R., Zaharia, T., Dumitrescu, E., Alexandrov, L. (1983). Données preliminaires sur la reproduction artificielle de la truite-arc-en-ciel elevée en eau marine pontique. Cercetări Marine - Recherches Marines, 16, 217-226.

IPCC. (2014). Climate Change 2014: Synthesis Report. Contribution of Working Groups I, II and III to the Fifth Assessment Report of the Intergovernmental Panel on Climate Change [Core Writing Team, R.K. Pachauri and L.A. Meyer (eds.)]. IPCC, Geneva, Switzerland, $151 \mathrm{pp}$.

IPCC. (2019). Summary for Policymakers. In: IPCC Special Report on the Ocean and Cryosphere in a Changing Climate [H.-O. Pörtner, D.C. Roberts, V. MassonDelmotte, P. Zhai, M. Tignor, E. Poloczanska, K. Mintenbeck, A. Alegría, M. Nicolai, A. Okem, J. Petzold, B. Rama, N.M. Weyer (eds.)].

IRA-STRATEGMA (2020). Situational analysis of the situation of the fisheries sector in Bulgaria. BG14MFOP001-7.001 Technical assistance of Maritime Affairs and Fisheries Operational Programme, pp. 393.

Jensen, O., Wroldsen, A.S., Lader P.F., Fredheim, A., Heide, M. (2007). Finite element analysis of tensegrity structures in offshore aquaculture installations. Aquacultural Engineering, 36(3), 272-84.

Jingchao, Z., and Kotani, K. (2012). The determinants of household energy demand in rural Beijing: Can environmentally friendly technologies be effective? Energy Economics, 34 (2), 381-388. https://doi.org/10.1016/j.Eneco.2011.12.011

Jonsson, B., Jonsson, N. (2009). A review of the likely effects of climate change on anadromous Atlantic salmon, Salmo salar and brown trout, Salmo trutta, with particular reference to water temperature and flow, Journal of Fish Biology, 75, 2381-2447. https://doi.org/10.1111/j.10958649.2009.02380.x

Karayücel, S., Çelik, M. Y, Karayücel I, Erik. G., (2010). Growth and Production of Raft Cultivated Mediterranean Mussel (Mytilus galloprovincialis Lamarck, 1819) in Sinop, Black Sea. Turkish Journal of Fisheries and Aquatic Sciences, 10, 09-17. https://doi.org/10.4194/trjfas.2010.0102

Karayücel, S., Karayücel, I.., Erdem, M., Saygun, S. And Uyan, O., (2003). Growth and Production in Long-Line Cultivated Mediterranean Mussel (Mytilus galloprovincialis) in Sinop, Black Sea. The Israeli Journal of Aquaculture-Bamidgeh, 55(3), 169-178.

Karlsen C., Hjerde E., Klemetsen T., Willassen N.P. (2017). Pan genome and CRISPR analyses of the bacterial fish pathogen Moritella viscosa. BMC Genomics, 18, 313. https://doi.org/10.1186/s12864-017-3693-7

Khan, M.A.Q., Ahmed, S.A., Catalin, B., Khodadoust, A., Ajayi, O., Vaughn, M. (2006). Effect of temperature on heavy metal toxicity to juvenile crayfish, Or-connects immunize (Hagen), Environmental Toxicology, 21 (5), 513-520.

Khavtasi, M.; Makarova, M.; Lomashvili, I.; Phartsvania, A.; Moth-Poulsen, T.; Woynarovich, A. (2010) Review of fisheries and aquaculture development potentials in Georgia. FAO Fisheries and Aquaculture Circular. No. 1055/1. Rome, FAO. 2010. 82 p.

Kideys, A.E. (2002). Fall and rise of the Black Sea ecosystem. Science, 297.5586, 1482-1484.

Kideys, A.E. (2007). Knowledge from the Black Sea: A role model for ecosystem management. Rapp. Comm. int. Mer. Médit., 38.

Kılıç, A., (2008). Possible effects of global warming and aquatic species, Kemaliye 5th Traditional Fisheries Science and Culture Meeting (National), Erzincan. (In Turkish)

Kirpenko, N., Krot, Y. \& Usenko, O. (2019). Surface Waters "Blooms", Fundamental and Applied Aspects. Hydrobiological Journal, 55(2), 18-30.

Kirpenko, N., Krot, Y. \& Usenko, O. (2020). Toxicological Aspects of the Surface Water "Blooms" (a Review). Hydrobiological Journal, 56, 3-16.

Klisarova, D., Gerdzhikov, D., Kostadinova, G., Petkov, G., Cao, X., Song, Ch. \& Zhou, Y. (2020). Bulgarian marine aquaculture: Development and prospects - A review. Bulgarian Journal of Agricultural Science, 26, 163-174.

Kovalenko, V. \& Goncharuk, V. (2019). Ecological State of Aquatic Ecosystems of Ukraine Using the Dnipro River as an Example. Journal of Water Chemistry and Technology, 41, 151-157.

Kras, S., Hrytsynyac, I. \& Kras, M. (2009). The influence microadding cobaltum and zincum on condition of system of antioxidant defence and a process of lipid peroxidation in the carp tissues. Fisheries Science of Ukraine, 1, 93-99.

Küçük, A. and Yıldırım, Y. (2001). Important viral diseases of fish. Journal of Etlik Vet Mikrobiyol, 28 (1), 13-22. (In Turkish)

Kukharev, N. and Romanov, V. (1998). The Fishery Industry in Ukraine. EASTFISH Fishery Industry. Volume 13.

Lado-Insua, T., Ocampo, F.J., Moran, K. (2009). "Offshore mussel aquaculture: new or just renewed?" Oceans '09 IEEE Bremen: Balancing Technology with Future Needs, art. No. 527826

Lebedev, S.A., Kostianoy, A.G., Bedanokov, M.K., Akhsalba, A.K., Berzegova, R.B. and Kravchenko, P.N. (2017) Climate changes of the temperature of the surface and level of the Black Sea by the data of remote sensing at the coast of the Krasnodar Krai and Republic of Abkhazia. Ecological Montenegrina, 14, 14-20.

Lee, S.K. and Dang, T.A. (2018). Application of AquaCrop model to predict sugarcane yield under the climate change impact: A case study of Son Hoa district, Phu Ye $\mathrm{n}$ province in Vietnam. Research on Crops, 19(2), 310-314.

Le Gouvello R, Hochart L-E, Laffoley D, Simard F, Andrade, C., Angel, D., Callier, M., De Monbrison, D., Fezzardi, D., Haroun, R., Harris, A., Hughes, A., Massa, F., Roque, E., Soto, D., Stead, S., Marino, G. (2017). Aquaculture and marine protected areas: Potential opportunities and 
synergies. Aquatic Conservation: Marine and Freshwater Ecosystems, 27, 1-13.

Leng, L.; Li, J.; Wen, Z.; Zhou, W. (2018). Use of microalgae to recycle nutrients in aqueous phase derived from hydrothermal liquefaction process. Bioresource Technology, 256, 529-542.

Liao, I.C., \& Huang, Y.S. (2000). Methodological approach used for the domestication of potential candidates for aquaculture in Recent advances in Mediterranean aquaculture finfish species diversification. Zaragoza: CIHEAM, (Cahiers Options Méditerranéennes; n. 47). Seminar of the CIHEAM Network on Technology of Aquaculture in the Mediterranean on 'Recent advances in Mediterranean aquaculture finfish species diversification', 1999/05/24-28, Zaragoza (Spain). 394 pp.

Llewellyn, L.E. (2010). Revisiting the association between sea surface temperature and the epidemiology of fish poisoning in the South Pacific: Reassessing the link between cig-water and climate change, Toxicon, 56 (5), 691-697.

Longo, S.; d'Antoni, B.M.; Bongards, M.; Chaparro, A.; Cronrath, A.; Fatone, F.; Lema, J.M., Miguel MauricioIglesias, M., Soares, A., Hospido, A. (2016). Monitoring and diagnosis of energy consumption in wastewater treatment plants. A state of the art and proposals for improvement. Applied Energy, 179, 1251-1268.

Lorenzen, K., Beveridge, M.C.M., \& Mangel, M. (2012). Cultured fish: integrative biology and management of domestication and interactions with wild fish. Biological Reviews of the Cambridge Philosophical Society 87(3), 639-60.

https://doi.org/10.1111/j.1469-185X.2011.00215.x

Lounas, R., Kasmi, H., Chernai, S., Amarni, N., Ghebriout, L., Meslem-Haoui, N. \& Hamdi, B. (2020). Towards sustainable mariculture: some global trends. Thalassas, 36, 447-456. https://doi.org/10.1007/s41208-02000206-y

Macias, J.C., Avila Zaragozá, P., Karakassis, I., Sanchez-Jerez, P., Massa, F., Fezzardi, D., Yücel Gier, G., Franičević, V., Borg, J.A., Chapela Pérez, R.M., Tomassetti, P., Angel, D.L., Marino, G., Nhhala, H., Hamza, H., Carmignac, C. \& Fourdain, L. (2019). Allocated zones for aquaculture: a guide for the establishment of coastal zones dedicated to aquaculture in the Mediterranean and the Black Sea. General Fisheries Commission for the Mediterranean. Studies and Reviews. No 97. Rome, FAO. 90pp.

MAFF (2014). Multiannual National Strategic Plan for Aquaculture in the Republic of Bulgaria (2014-2020), pp 47.

MAFF (2020). Annual report on the state and development of agriculture. 2020 Agricultural Report. pp. 323.

Magnusson H.B., Fridjonsson O.H., S. Andresson O.S., Benediktsd E., Gudmundsdotitir S., Andreisd V. 1994. Renibacterium salmoninarum, the Causative Agent of Bacterial Kidney Disease in Salmonid Fish, Detected by Nested Reverse Transcription-PCR of 16S rRNA Sequences. Applied and Environmental Microbiology, 4580-4583.

Maritime Spatial Plan for Black Sea. (2020). MARSPLAN. Retrieved Oct 22, 2020 from http://www.marsplan.ro/en/

MARSEA. (2020). European MSP Platform. Retrieved Oct 13, 2020 from https://www.msp-platform.eu/projects/marsea- development-integrated-framework-marine-spatialplanning-romania

Massa, F., Onofri, L., \& Fezzardi, D. (2017). Aquaculture in the Mediterranean and the Black Sea: A Blue Growth perspective. pp 93-123 in Handbook on the Economics and Management of Sustainable Oceans, pp 624 Edward Elgar Publishing.

Mathews, C.P. \& Samuel, M. (1992). A simple and objective bioeconomic index for choosing species for culture, Naga, The WorldFish Center, 15(2), 19-21.

Meaden, G.J., Aguilar-Manjarrez, J., Corner, R.A., O'Hagan, A.M. \& Cardia, F. (2016). Marine spatial planning for enhanced fisheries and aquaculture sustainability - its application in the Near East. FAO Fisheries and Aquaculture Technical Paper No. 604. Rome, FAO

MEDAR/MEDATLAS II. (2020). Mediterranean Data Archaeology and Rescue. Retrieved Oct 09, 2020 from http://www.ifremer.fr/medar/

Medinets, S., Moklyachuk, L., Utkina, K., Howard, C., Sutton, M., Medinets, V. (2017). Development of Nitrogen Load Assessment System in the Dniester River Catchment. Kharkiv National V.N. Karazin University Herald, 16, 123131.

Memis, D., Demir, N., Eroldogan, O.T., \& Kucuk, S. 2002. Aquaculture in Turkey. The Israeli Journal of Aquaculture, 54(1), 3-9.

Memiş, D., Ercan, E., Kurtoğlu, i.z., Akbulut, B., Aydın, i.., Çakmak, E., Savaş, H., Çavdar, Y.ve Aksungur, N. 2008. Gonand developments of Sturgeon and egg stripping. Production and Preservation Workshop for Sturgeon Species, October 30-31, 2008. Workshop Pub. Book, Sayfa: 81-85. (In Turkish)

Miladinova, S., Stips, A., Garcia-Gorriz, E. and Moy, D.M. (2016). Black Sea ecosystem model: setup and validation. EUR 27786. https://doi.org/10.2788/601495

Miladinova, S., Stips, A., Garcia-Gorriz, E. and Moy, D.M. (2017) Black Sea thermohaline properties: Long-term trends and variations. Journal of Geophysical Research Oceans, 122, 5624-5644. https://doi.org/10.1002/2016JC012644

Ministry of Agrarian Policy and Food of Ukraine (Minagro of Ukraine). (2017). Adaptation strategy to climate change in agriculture, forestry and fisheries of Ukraine until 2030. Draft order of the Cabinet of Ministers of Ukraine Retrieved from https://www.uahhg.org.ua/wpcontent/uploads/2019/08/Стратегія-адаптації-дозміни-клімату-сільського-лісового-та-рибногогосподарств-України-до-2030-року_29.05.19.pdf

Ministry of Agriculture and Forestry. (2020). Statistics of fishery products in Turkey. $21 \mathrm{pp}$.

Mimura, N. (2013). Sea-level rise caused by climate change and its implications for society. The Proceedings of the Japan Academy, Series B Physical and Biological Sciences, 89(7), 281-301. https://doi.org/10.2183/pjab.89.281

Mishra, A., Nam, G.H., Gim, J.A., Lee, H.E., Jo, A., Kim, H.S. (2018). Current Challenges of Streptococcus Infection and Effective Molecular, Cellular, and Environmental Control Methods, Aquaculture. Molecules and Cells, 41(6), 495-505.

https://doi.org/10.14348/molcells.2018.2154

MISIS. (2020). European MSP Platform. Retrieved Oct 13, 2020 from https://www.msp-platform.eu/practices/misisblack-sea-marine-atlas

Mohamad N., Amal M.N.A Yasin I.S.Md., Saad M.Z., Nasruddin N.S., Al-saari N., Mino S., Sawabe T. (2019). Vibriosis in 
cultured marine fishes: a review. Aquaculture, 512, 734289.

https://doi.org/10.1016/j.aquaculture.2019.734289

Mol, S. and Doğruyol, H. (2012). The effects of Climate Change on Fisheries Production and Consumption. Journal of Fisheries Sciences, 6 (4), 341-356. https://doi.org/10.3153/jfscom.akdeniz008 (In Turkish)

Molony, B.W., R. Lenanton, R., G. Jackson, G. and Norriss, J. (2005). Stock enhancement as a fisheries management tool. Reviews in Fish Biology and Fisheries, 13 (4), 409432.

Moore, S.K., Trainer, V.L., Mantua, N.J., Parker, M.S., Laws, E.A., Backer, L.C., Fleming, L.E., (2008). Impacts of climate variability and future climate change on harmful algal blooms and human health, Environmental Health, 7 (Suppl 2): S2. https://doi.org/10.1186/1476-069X-7-S2-S4

Murray, J.W.; Jannasch, H.W.; Honjo, S; Anderson, R.F.; Reeburgh, W.S.; Top, Z.; Friederich, G.E.; Codispoti, L.A.; Izdar, E. (1989). Unexpected changes in the oxic/anoxic interface in the Black Sea. Nature, 338 (6214), 411-413.

Murray, F., Bostock, J., Fletcher, M. (2014). Review of RAS technologies and their commercial application. Final report. Retrieved from http://www.hie.co.uk/

Myslyva, T. (2016). Heavy metals and microelements in organs and tissues of representatives of ichthyofauna of small rivers of Zhytomyr Polisya. Bulletin of Zhytomyr National Agroecological University, 1(53), 22-34.

Nardelli, B.B., Colella, S., Santoleri, R., Guarracino, M. and Kholod, A. (2010) A re-analysis of Black Sea surface temperature. Journal of Marine Systems, 79 (1-2), 5064. https://doi.org/10.1016/j.jmarsys.2009.07.001

Naylor, R. and Burke, M. (2005). Aquaculture and ocean resources: raising tigers of the sea. Archived 2010-07-16 at the Wayback Machine Annual Review of Environmental Resources, 30, 185-218.

NEF. (2016). Fish dependence - 2016 update. The reliance of the EU on fish from elsewhere. New Economics Foundation (NEF).

Negreanu-Pîrjol, B., Negreanu-Pîrjol, T., Bratu, M., Sîrbu, R., Roncea, F., Paraschiv, G., Meghea, A. (2011). Physicalchemical characterization of some green and red macrophyte algae from the Romanian Black Sea littoral. Scientific Study and Research: Chemistry and Chemical Engineering, Biotechnology, Food Industry, 12(2), 173184. https://doi.org/10.1134/S1063074017020110

Neori, A., Chopin, T., Troell, M., Buschmann, A.H., Kraemer, G.P., Halling, C., Shpigel, M., Yarish, C. (2004). Integrated aquaculture: rationale, evolution and state of the art emphasizing seaweed biofiltration in modern mariculture. Aquaculture, 231 (1-4), 361-391.

Niţă V., Zaharia T., Maximov V., Nicolae C.G. (2012). Preliminary Data Regarding the Possibilities of Rearing the North Sea Turbot Scophthalmus maximus at the Romanian Littoral. Proceedings of the International Conference "Scientific and Technical Innovation in the Blue Economic Zone", Yantai, China, Didactic and Pedagogic Publishing, Bucharest, ISBN 978-973-30-33059: $160-167$

Niţă, V., Theodorou, J., Nicolaev, S., Nenciu, M.I. (2019) Advancing Shellfish Aquaculture as a Sustainable Food Procurement Option in Emerging Black Sea Riparian Countries: Romania Country Report. Scientific Papers. Series D. Animal Science., LXII (2), ISSN 2285-5750; ISSN CD-ROM 2285-5769; ISSN Online 2393-2260; ISSN-L 2285-5750.
Niţă, V., Nenciu, M.I. (2017). Using the Recirculating Technology in a Pilot-System for Mariculture at the Romanian Black Sea Coast. Journal of Environmental Protection and Ecology, 18 (1), 255-263.

Niță, V., Nenciu, M.I., Nicolae, C.G. (2018a). Experimental Rearing of the Golden Gray Mullet Liza aurata (Risso, 1810) in a Recirculating System at the Black Sea. "Agriculture for Life, Life for Agriculture" Conference Proceedings, 1 (1), 149-154. https://doi.org/10.2478/alife-2018-0022

Niță, V., Nenciu, M.I., Raykov, V., Nicolae, C.G. (2018b). First Attempt of Rearing the Siberian Sturgeon (Acipenser baerii Brandt, 1869) in Black Sea Water. AgroLife Scientific Journal, ISSN 2285-5718; ISSN CD-ROM 22855726; ISSN ONLINE 2286-0126; ISSN-L 2285-5718, $97-$ 102.

Niță, V., Nenciu, M.I. (2020a). Practical Guideline for Shellfish Culture. CD Press Publishing, Bucharest, ISBN 978-606528-510-1, $81 \mathrm{p}$.

Niţă, V., Nenciu, M.I. (2020b). Biological and Ethological Response of Black Sea Golden Grey Mullet Chelon auratus (Risso, 1810) Fries to Different Salinities and Temperatures. Turkish Journal of Fisheries and Aquatic Sciences, 20 (11), 777-783.

Niţă, V., Massa, F., Fourdain, L., Nenciu, M.I. 2020. Establishing the Suitability of the Agigea - Eforie Area for Designation as Allocated Zone for Aquaculture (AZA) and for Unlocking the Potentiality of Mariculture in Romania. Cercetări Marine, Issue 50/2020, ISSN 0250-3069, pp. 152-173.

Noyes, P.D., McElwee, M.K., Miller, H.D., Clark, B.W., Van Tiem, L.A., Walcott, K.C., Erwin, K.N., Levin, E.D., (2009). The toxicology of climate change: Environmental contaminants in a warming world, Environment International, 35 (6), 971-986.

Oguz T., Gilbert D. (2007). Abrupt transitions of the top-down controlled Black Sea pelagic ecosystem during 19602000: evidence for regime shifts under strong fishery exploitation and nutrient enrichment modulated by climate-induced variations. Deep-Sea Research I, 54, 220-242.

Ojeda, J., (2015). Advancing aquaculture innovation pp 72-82 In Regional Conference "Blue Growth in the Mediterranean and the Black Sea: developing sustainable aquaculture for food security", 9-11 December 2014, Bari, Italy, edited by Fabio Massa, Riccardo Rigillo, Dominique Bourdenet, Davide Fezzardi, Aurora Nastasi, Hélène Rizzotti, Wasseem Emam and Coline Carmignac. FAO Fisheries and Aquaculture Proceedings No. 46. Rome.

Okumuş, i., Kurtoglu I.Z. \& Atasaral, ş. (2007). General Overview of Turkish Sea Trout (Salmo trutta L.) Populations, In: G. Harris and N. Milner (Eds.), Sea Trout: Biology, Conservation and Management. Blackwell Publishing Ltd., London: 115-128.

Onără D., Holoștenco D., Paraschiv M., Suciu R. (2014). Preliminary genetic variability of Lower Danube River young of the year (YOY) beluga sturgeon Huso huso (Linnaeus, 1758) using mtDNA markers. Journal of Applied Ichthyology, 30, 1286-1289.

Onciu, T. (1984). Donnèes sur la correlation entre la nouriture et la croissance de crevettes (Palaemon adspersus). Rapp. Comm. Int. Mer. Mèdit., CIESM, Monaco, 29 (4), 127-29. 
Özdemir, A., Akbulut, B., 2007. Researches on Present Status of Sturgeon Population and Rearing Possibilities in Turkey. Program of International Scientific-Practical Seminar On Sturgeon Breeding, BIOS, March 12-16, 2007, Astrakhan.

Özsoy, E. (2017). Identifying the most suitable areas for sea cage fish farming in Ordu Province. University of Ordu Institute for Graduate Studies in Science and Technology Department of Fisheries Technology Engineering, 2017 MSc. Thesis, 57p.

Parus, A., and Karbowska, B. (2020). Marine Algae as Natural Indicator of Environmental Cleanliness. Water Air Soil Pollut, 231, 97. https://doi.org/10.1007/s11270-0204434-0

PEGASO. (2020). European MSP Platform. Retrieved Oct 12, 2020 from

https://www.msp-platform.eu/practices/pegasospatial-data-infrastructure

PlanCoast. (2020). Retrieved Nov 3, 2020 from http://www.plancoast.eu/

Polat, H., Özen, M.R., \& Keskin, Y.S. (2018). The Embryonic Development of Black Sea Turbot (Psetta maxima Linnaeus, 1758) Eggs in Different Incubation Temperatures and Salinities. Turkish Journal of Fisheries and Aquatic Sciences, 18(3), 475-482. https://doi.org/10.4194/1303-2712-v18_3_13

Porumb, F. (1999-2000). Recherches d'aquaculture. Cercetări Marine - Recherches Marines, 32-33, 82-87.

Powell, A. and Scolding, J.W.S. (2016). Direct application of ozone in aquaculture systems. Reviews in Aquaculture, 10 (2), 424-438.

Price, C., Black, K.D., Hargrave, B.T., Morris, J.A. (2015). Marine cage culture and the environment: effects on water quality and primary production. Aquaculture Environment Interaction., 6, 151-174.

Prodanov, K. Mikhailov, K.; Daskalov, G. Maxim, C. Chashchin, A. Arkhipov, A. Shlyakhov, V. Ozdamar, E. (1997). Environmental management of fish resources in the Black Sea and their rational exploitation. Studies and Reviews. General Fisheries Council for the Mediterranean. No. 68. FAO, Rome, 178p.

Reid, G.K., Chopin, T., Robinson, S.M.C., Azevedo, P., Quinton, M., Belyea, E. (2013). Weight ratios of the kelps, Alaria esculenta and Saccharina latissima, required to sequester dissolved inorganic nutrients and supply oxygen for Atlantic salmon, Salmo salar, in Integrated Multi-Trophic Aquaculture systems. Aquaculture, 408409, 34-46.

Reith M.E., Singh R.K., Curtis B., Boyd J.M., Bouevitch A., Kimball J., MunhollandJ., Murphy C., Sarty D., Williams J., Nash J.HE., Johnson S.C., Brown L.L. (2008). The genome of Aeromonas salmonicida subsp. salmonicida A449: insights into the evolution of a fish pathogen. $B M C$ Genomics, 9, 427. https://doi.org/10.1186/1471-21649-427

Report TR90 (2012). Doğu Karadeniz Bölgesi Su Ürünleri Sektör Raporu. Sözleşme No: TR90/11/DFD/21. Eastern Black Sea Development Agency Central Fisheries Research Institute. Romanian National Agency for Fishing and Aquaculture. (in preparation). National Multiannual Strategic Plan for Aquaculture Development 2021 2030, unpublished data.

Republic of Turkey. (2004). Aquaculture Regulation No. 25507 of 29 June 2004.

Resolution on guidelines on allocated zones for aquaculture
(AZA), GFCM/36/2012/1. (2020). The General Fisheries Commission for the Mediterranean (GFCM).

Retrieved Oct 11, 2020 from

https://gfcmsitestorage.blob.core.windows.net/docum ents/Decisions/GFCM-Decision--RES-

GFCM_36_2012_1-en.pdf

ROMFISH. (in preparation). Romanian Fish Farmers' Association, adapted from National Multiannual Strategic Plan for Aquaculture Development 2021 2030.

Roșioru, D., Coatu, V., Oros, A., Vasiliu, D., Țigănuș, D. (2012). Marine environment quality for the growth and exploitation of the main mollusks from the Romanian Black Sea Coast according to the EU legislation. Journal of Environmental Protection and Ecology, 13(3A), 17991805.

Rozas M. and Enriquez R. (2014). Piscirickettsiosis and Piscirickettsia salmonis in fish: a review. Journal of Fish Diseases, 37, 163-188.

https://doi.org/10.1111/jfd.12211

Russian Federation. (2013). On Aquaculture (Fish Farming) and on Amendments to Certain Legislative Acts of the Russian Federation. 2013. Federal Law no. 148-FL July 2, 2013 Retrieved April 8, 2021 from http://internet.garant.ru (In Russian)

Russian Federation. (2020). Results of the activities of the Federal Agency for Fisheries in 2019 and tasks for 2020. 2020. Material for Meeting of the Board of the Federal Agency for Fisheries. September, 25, 2020. Retrieved April 27, 2021 from

http://fish.gov.ru/files/documents/ob_agentstve/kolleg iya/itogi_2020.pdf (in Russian)

Russian Federation. (2021). Results of the activities of the Federal Agency for Fisheries in 2020 and tasks for 2021. 2021. Material for Meeting of the Board of the Federal Agency for Fisheries. April 2021. Retrieved April 8, 2021 from

http://fish.gov.ru/files/documents/ob_agentstve/kolleg iya/itogi_2021.pdf (in Russian)

Ruzzante, D.E. (1994). Domestication effects on aggressive and schooling behaviour in fish. Aquaculture, 120(1-2), 1-24. https://doi.org/10.1016/0044-8486(94)90217-8

Sabrié.M.L., Gibert-Brunet, E., Mourier, T. (2016). The Mediterranean Region under Climate Change A scientifique update IRD Edition, Marseill ISBN : 978-27099-2219-7

Sağlam, N.E., Düzgüneş, E., Balık, İ., (2008). Global Warming and Climate Change, Ege University Journal of Fisheries, 25(1), 89-94. (In Turkish)

Salihoglu, I. (2000). Black Sea Integrated Coastal and Shelf Zone Monitoring and Modeling (INCOM) Program Science Plan. Report-248, SALIHOGLU, 2000 Committee on the Challenges of Modern Society (CCMS).

Sanchez-Jerez, P., Karakassis, I., Massa, F., Fezzardi, D., AguilarManjarrez, J., Soto, D., Chapela, R., Avila, P., Macias, J.C., Tomassetti, P., Marino, G., Borg, J.A., Franičević, V., Yücel-Gier, G., Fleming, I.A., Biao, X., Nhhala, H., Hamza, H., Forcada, A., Dempster, T. (2016). Aquaculture's struggle for space: the need for coastal spatial planning and the potential benefits of Allocated Zones for Aquaculture (AZAs) to avoid conflict and promote sustainability. Aquacult Environ Interact, 8, 41-54.

Schiedek, D., Sundelin, B., Readman, J.W., Macdonald, R.W. (2007). Interactions between climate change and contaminants, Marine Pollution Bulletin, 54, 1845-1856. 
Scorvo-Filho, J.D., Frascá-Scorvo, C.M.D., Cordeiro, J.M.A., \& Souza, F.R.A. (2010). A tilapicultura e seus insumos, relações econômicas. Revista Brasileira de Zootecnia, 39, 112-118. https://doi.org/10.1590/S1516-35982010001300013

Sekhniashvili, D. and Kathijotes, N. (2018). Georgia: Blue Economy in the Marine Sector. Research Institute for European and American Studies (RIEAS), Research Paper N. 176, $21 \mathrm{pp}$.

Shalva, J. (2002). The rivers of the Black Sea. European Environmental Agency technical report. EEA, 2002.

Shapiro, G.I., Aleynik, D.L. and Mee, L.D. (2010) Long term trends in the sea surface temperature of the Black Sea. Ocean Science, 6, 491-501. https://doi.org/10.5194/os6-491-2010

Shevchenko, O. (2014). Climate Change Vulnerability Assessment: Ukaine. s.l., Eastern Partnership Climate Forum and Working Group of Climate Change NGOs.

Shevchenko, P.G., Martseniuk, N.O., Bazaeva, A.V., Khalturin, M.B., Boiko, Y.V., 2019. Influence of climate change on species composition and quantity of Dnipro reservoirs ichthyofauna. Kyiv, Scientific Methodological Center "Agroosvita".

Sirakov, I.; Velichkova, K.; Stoyanova, S.; Staykov, Y. (2015). The importance of microalgae for aquaculture industry. Review. Int. J. Fish. Aquat. Stud., 2, 81-84.

Sokolova I.M. and Lannig G. (2008). Interactive effects of metal pollution and temperature on metabolism in aquatic ectotherms: implications of global climate change. Climate Research., 37, 181-201.

https://doi.org/10.3354/cr00764

Soto, D., White, P. and Yücel-Gier, G. (2009). TCP/TUR/3101: Developing a roadmap for Turkish marine aquaculture site selection and zoning using an ecosystem approach to management in FAN - FAO Aquaculture Newsletter. No.43. December 2009 Rome, FAO. 2009 Pag.8-9.

Sorensen, J., Gable, F., Gardner, M. and Hinrichsen. (1997). The Black Sea: Another Environmental Tragedy in Our Times? In: $3^{\text {rd }}$ Intern. Conf. on the Mediter. Coastal Environ., MEDCOAST ' 97 (E. Özhan, ed.), Quawra, Malta, Vol. 2, p. 741-752. Ankara, Turkey.

Sorokin, Y.I. (1983) The Black Sea. In Estuaries and Enclosed Seas. Ecosystems of the World, 26, 253-291.

Stanev, E. (2005). "Black Sea dynamics." Oceanography, 18 (2), 56-75.

State Statistics Service of Ukraine, 2019. Extraction of aquatic bioresources in 2019. s.I.: s.n.

Stelmakha, L.V. and Stepanovab, O.A. (2020). Effect of Viral Infection on the Functioning and Lysis of Black Sea Microalgae Tetraselmis viridis (Chlorophyta) and Phaeodactylum tricornutum (Bacillariophyta). Inland Water Biology, 13 (3), 417-424.

Stepanova, O.A. (2017). Interaction between algal viruses and the mussel Mytilus galloprovincialis Lamarck, 1819 (Bivalvia: Mytilidae) in experiment, Russ. J. Mar. Biol., 43, 127-131.

STRATEGMA-JUNCTION (2018). Marketing report on fish species and fish products with good and very good market potential. Maritime Affairs and Fisheries Operational Programme pp.184.

Strezov, A. and Nonova, T. (2005). Environmental Monitoring of Heavy Metals in Bulgarian Black Sea Green Algae. Environmental Monitoring and Assessment., 105(1-3), 99-110.

Suantika, G., Dhert, P., Sweetman, E., O’Brien, E., Sorgeloos, P.
(2003). Technical and economical feasibility of a rotifer recirculation system. Aquaculture, 227, 173-189.

Supporting the MSFD directive in the Black Sea. (2020). Copernicus Marine Service. Retrieved Nov 03, 2020 from https://marine.copernicus.eu/services/usecases/supporting-msfd-directive-black-sea

Sytnik, Y., Arsan, O. \& Zasekin, D. (2008). Chlorine organic pesticides in fish of Dniepr river, Dnieper reservoirs and Dnieper-Bug Estuary. Fisheries Science of Ukraine, 4, 5565.

Szeląg-Sikora, A., Niemiec, M., Sikora, J. (2016). Assessment of the content of magnesium, potassium, phosphorus and calcium in water and algae from the Black Sea in selected bays near Sevastopol. Journal of Elem., 21(3), 915-926. https://doi.org/10.5601/jelem.2015.20.4.969

Tabak, i.., Aksungur, M., Zengin, M., Yılmaz, C., Aksungur, N., Alkan, A., Zengin, B. \& Misır, D.S. (2001). Bioecological Characteristics and Culture of Black Sea Trout (Salmo trutta labrax), TAGEM/HAYSUD /98/12/01/007, Trabzon Central Fisheries Research Institute, Project Work, Trabzon.

Telesca, L., Peck, L.S., Sanders, T., Thyrring, J., Sejr, M.K., Harper, E.M. (2019). Biomineralization plasticity and environmental heterogeneity predict geographical resilience patterns of foundation species to future change. Global Change Biology, 25(12), 4179-4193.

Teletchea, F., \& Fontaine, P. (2012). Levels of domestication in fish: implications for the sustainable future of aquaculture. Fish and Fisheries, 15(2), 181-195. https://doi.org/10.1111/faf.12006

Tirado, M.C., Clarke, R., Jaykus, L.A., McQuat-ters-Gollop, A., Frank, J.M. (2010). Climate change and food safety: a review, Food Research International, 43 (7), 1745-1765.

Toranzo, A.E., Magarinos, B., Romalde, J.L. (2005). A review of the main bacterial fish diseases in mariculture systems. Aquaculture, 246, 37-61.

Tucker, C.M., Cadotte, M.W., Carvalho, S.B., Davies, T.J., Ferrier, S., Fritz, S.A., Grenyer, R., Helmus, M.R., \& Jin, L.S. (2017). A guide to phylogenetic metrics for conservation, community ecology and macroecology: A guide to phylogenetic metrics for ecology. Biological Reviews., 92(2), 698-715. https://doi.org/10.1111/brv.12252.

Tugrul, S., Basturk, O., Saydam, C., \& Yilmaz, A. (1992). Changes in the hydrochemistry of the Black Sea inferred from water density profiles. Nature, 359 (6391), 137-139.

TUIK. (2020). Turkish Statistical Institute, Fisheries Statistics Database. Retrieved Nov 8, 2020 from https://biruni.tuik.gov.tr/medas/?kn=97\&locale=en

Türker, A., Yiğit, M., Ergün, S., Karaali, B. and Erteken, A. (2005). Potential of poultry by-product meal as a substitute for fishmeal diets for Black Sea turbot Scophthalmus maeticus: growth and nutrient utilization in winter. The Israeli Journal of Aquaculture-Bamidgeh, 57(1), 49-61.

Turkish Ministry of Agriculture and Forestry (2020). Fisheries Statistics (In Turkish). Ankara. Retrieved from https://www.tarimorman.gov.tr/BSGM/Belgeler/Icerikl er/Su\%20\%C3\%9Cr\%C3\%BCnleri\%20Veri\%20ve\%20D\% C3\%B6k\%C3\%BCmanlar\%C4\%B1/Su\%C3\%9Cr\%C3\%BCnleri-\%C4\%B0statistikleri.pdf

Uçal, O. \& Benli, H.A. (1993). Seabass fish and its breeding. Ministry of Agriculture and Rural Affairs Fisheries Research Institute. Bodrum. Seri A, Pub. No. 9, 72 s.

UNEP/GEF. (1997). Global Environment Facility (GEF) Black Sea 
Transboundary Diagnostic Analysis. UNEP (United Nations Environment Programme), New York, U.S.

Ustaoğlu Tırıl, S., Zengin, M., Akbulut, B., Memis, D., Alagil, F., \& Dağtekin, M. (2011). A participatory approach to tagging and monitoring as an initial step in developing a sturgeon conservation strategy along the Turkish Black Sea Coast. Journal of Applied Ichthyology, 27(2), 411414.

Vyshnevskyi, V. (2019). Spatial temporal variability of algal bloom in the Dnipro reservoirs. Ukrainian Journal of Remote Sensing, 20, 18-27.

Wang, J.; Zhou, W.; Yang, H.; Wang, F.; Ruan, R. (2015). Trophic mode conversion and nitrogen deprivation of microalgae for high ammonium removal from synthetic wastewater. Bioresour. Technol., 196, 668-676.

Yanovych, D., Hrytsyniak, I. \& Shvets, T. (2016). Application of Salmonids (salmonidae) in the biomonitoring of aquatic environment (a review). Ribogospodarska Nauka Ukrainy, 1(35), 5-30.

Zaharia, T., Micu, D., Micu, S., Alexandrov, L., Dumitrescu, E. (2006). Experiments for Breeding of Autochtonous Shrimps at the Romanian littoral, Aiming to the Treatment of Resulted Effluents. Cercetări marineRecherches marines, 36, 145-160.

Zaharia, T., Maximov, V., Niță, V., Staicu, V., Lazăr, L., Sîrbu, R. (2008). Preliminary results regarding sturgeon breeding on the Romanian littoral. Cercetări Marine - Recherches Marines, 38, 207-222.

Zaharia, T., Niță, V., Nenciu, M.I. (2017). Background of Romanian aquaculture (in Romanian). Bucharest, CD Press Publishing, ISBN 978-606-528-393-0: $273 \mathrm{p}$.

Zaharia, T., Onea, D., Niţă, V., Maximov, V., Staicu, V., Lazăr, L., Sîrbu, R. (2011). Russian sturgeon (Acipenser gueldenstaedti): Comparative breeding in fresh and marine water on the Romanian littoral. Journal of Environmental Protection and Ecology, 12 (3A), 13861393.

Zaitsev, Y. and Mamaev, V. (1997). Biological diversity in the Black Sea: Main changes and ensuing conservation problems. In Proceedings of the Third International Conference on the Mediterranean Coastal Environment, MEDCOAST `97, p. 171.

Zamora, L.N., Yuan, X., Carton, A.G., Slater, M.J. (2016). Role of deposit-feeding sea cucumbers in integrated multitrophic aquaculture: progress, problems, potential and future challenges. Reviews in Aquaculture, 10(1), 5774. https://doi.org/10.1111/raq.12147

Zengin, M., \& Gümüs, A. (2013). An investigation on the recruitment of hatchery-reared turbot (Psetta maxima Pallas, 1811) juveniles to natural population in the eastern Black Sea. Rapp. Comm. int. Mer Médit, (40).

Zengin, M. (2002). Growth and sexual maturation of tagged hatchery-bred turbot Psetta maxima released and recaptured in the Black Sea. Aquaculture Studies (Yunus Research Bulletin), 2002(4).

Zengin, M., Polat, H., Kutlu, S., Gümüş, A., Başçınar, N.S., Emiral, E. (2005). Investigation of Natural Stock Inclusion and Bioecological Characteristics of Cultured Juvenile Turbot (Psetta maxima) Specimens. Central Fisheries Research Institute (SUMAE), Project Report. (In Turkish).

Zlateva, P., Dimitrov, R. (2019). Possibilities of using algae for renewable energy production in the Black Sea region. $11^{\text {th }}$ Electrical Engineering Faculty Conference (BulEF). 11-14 Sept. 2019. Varna, Bulgaria, Bulgaria. https://doi.org/10.1109/BulEF48056.2019.9030765

Zolotarev, V. (1996). The Black Sea ecosystem changes related to the introduction of new mollusc species. Marine Ecology, 17 (1-3), 227-236. 